\title{
Global Positioning System \\ Measurements on the Island of Hawaii from 1987 to 1990
}

\section{U.S. GEOLOGICAL SURVEY BULLETIN 2092}

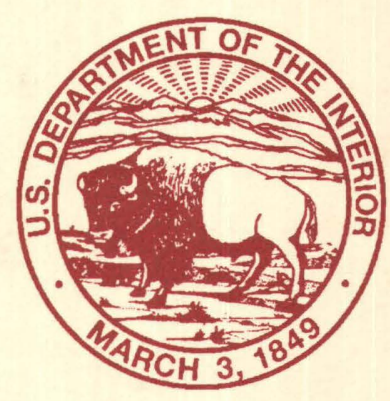




\section{AVAILABILITY OF BOOKS AND MAPS OF THE U.S. GEOLOGICAL SURVEY}

Instructions on ordering publications of the U.S. Geological Survey, along with prices of the last offerings, are given in the currentyear issues of the monthly catalog "New Publications of the U.S. Geological Survey." Prices of available U.S. Geological Survey publications released prior to the current year are listed in the most recent annual "Price and Availability List." Publications that are listed in various U.S. Geological Survey catalogs (see back inside cover) but not listed in the most recent annual "Price and Availability List" are no longer available.

Reports released through the NTIS may be obtained by writing to the National Technical Information Service, U.S. Department of Commerce, Springfield, VA 22161; please include NTIS report number with inquiry.

Order U.S. Geological Survey publications by mail or over the counter from the offices given below.

\section{BY MAIL}

\section{Books}

Professional Papers, Bulletins, Water-Supply Papers, Techniques of Water-Resources Investigations, Circulars, publications of general interest (such as leaflets, pamphlets, booklets), single copies of Earthquakes \& Volcanoes, Preliminary Determination of Epicenters, and some miscellaneous reports, including some of the foregoing series that have gone out of print at the Superintendent of Documents, are obtainable by mail from

\section{U.S. Geological Survey, Map Distribution Box 25286, MS 306, Federal Center Denver, CO 80225}

Subscriptions to periodicals (Earthquakes \& Volcanoes and Preliminary Determination of Epicenters) can be obtained ONLY from the

\section{Superintendent of Documents \\ Government Printing Office \\ Washington, DC 20402}

(Check or money order must be payable to Superintendent of Documents.)

\section{Maps}

For maps, address mail orders to

\section{U.S. Geological Survey, Map Distribution Box 25286, Bldg. 810, Federal Center Denver, CO 80225}

Residents of Alaska may order maps from

\author{
U.S. Geological Survey, Earth Science Information Center \\ 101 Twelfth Ave., Box 12 \\ Fairbanks, AK 99701
}

\section{OVER THE COUNTER}

\section{Books and Maps}

Books and maps of the U.S. Geological Survey are available over the counter at the following U.S. Geological Survey offices, all of which are authorized agents of the Superintendent of Documents.

- ANCHORAGE, Alaska - 4230 University Dr., Rm. 101

- LAKEWOOD, Colorado-Federal Center, Bldg. 810

- MENLO PARK, California-Bldg. 3, Rm. 3128, 345 Middlefield Rd.

- RESTON, Virginia-National Center, Rm. 1C402, 12201 Sunrise Valley Dr.

- SALT LAKE CITY, Utah-Federal Bldg., Rm. 8105, 125 South State St.

- SPOKANE, Washington-U.S. Post Office Bldg., Rm. 135, W. 904 Riverside Ave.

- WASHINGTON, D.C.-Main Interior Bldg., Rm. 2650, 18th and C Sts., NW.

\section{Maps Only}

Maps may be purchased over the counter at the U.S. Geological Survey offices:

- FAIRBANKS, Alaska-New Federal Building, 101 Twelfth Ave.

- ROLLA, Missouri-1400 Independence Rd.

- STENNIS SPACE CENTER, Mississippi-Bldg. 3101 


\section{Global Positioning System \\ Measurements on the Island of Hawaii from 1987 to 1990}

By John J. Dvorak, Arnold T. Okamura, Michael Lisowski, William H. Prescott, and Jerry L. Svarc

U.S. GEOLOGICAL SURVEY BULLETIN 2092

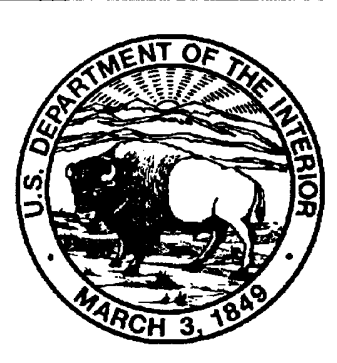




\title{
U.S. DEPARTMENT OF THE INTERIOR BRUCE BABBITT, Secretary
}

\author{
U.S. GEOLOGICAL SURVEY \\ Gordon P. Eaton, Director
}

For sale by

U.S. Geological Survey, Map Distribution

Box 25286, MS 306, Federal Center

Denver, CO 80225

\begin{abstract}
Any use of trade, product, or firm names in this publication is for descriptive purposes only and does not imply endorsement by the U.S. Government.
\end{abstract}

\section{Library of Congress Cataloging-in-Publication Data}

Global Positioning System measurements on the Island of Hawaii from 1987 to 1990 / by John J. Dvorak ... [et al.].

p. $\quad \mathrm{cm}$. - (U.S. Geological Survey bulletin ; 2092)

Incudes bibliographical references.

1. Earth movements-Hawaii-Kilauea Volcano Region-Measurement. 2. Volcanism-Hawaii-Kiluea Volcano. 3. Global Positioning System. I. Dvorak, John (John J.) II. Series.

QE75.B9 no. 2092

[QE598.5.U6]

$557.3 \mathrm{~s}-\mathrm{dc} 20$

94-13918

$\left[551.209969^{\prime} 1\right]$ 


\section{CONTENTS}

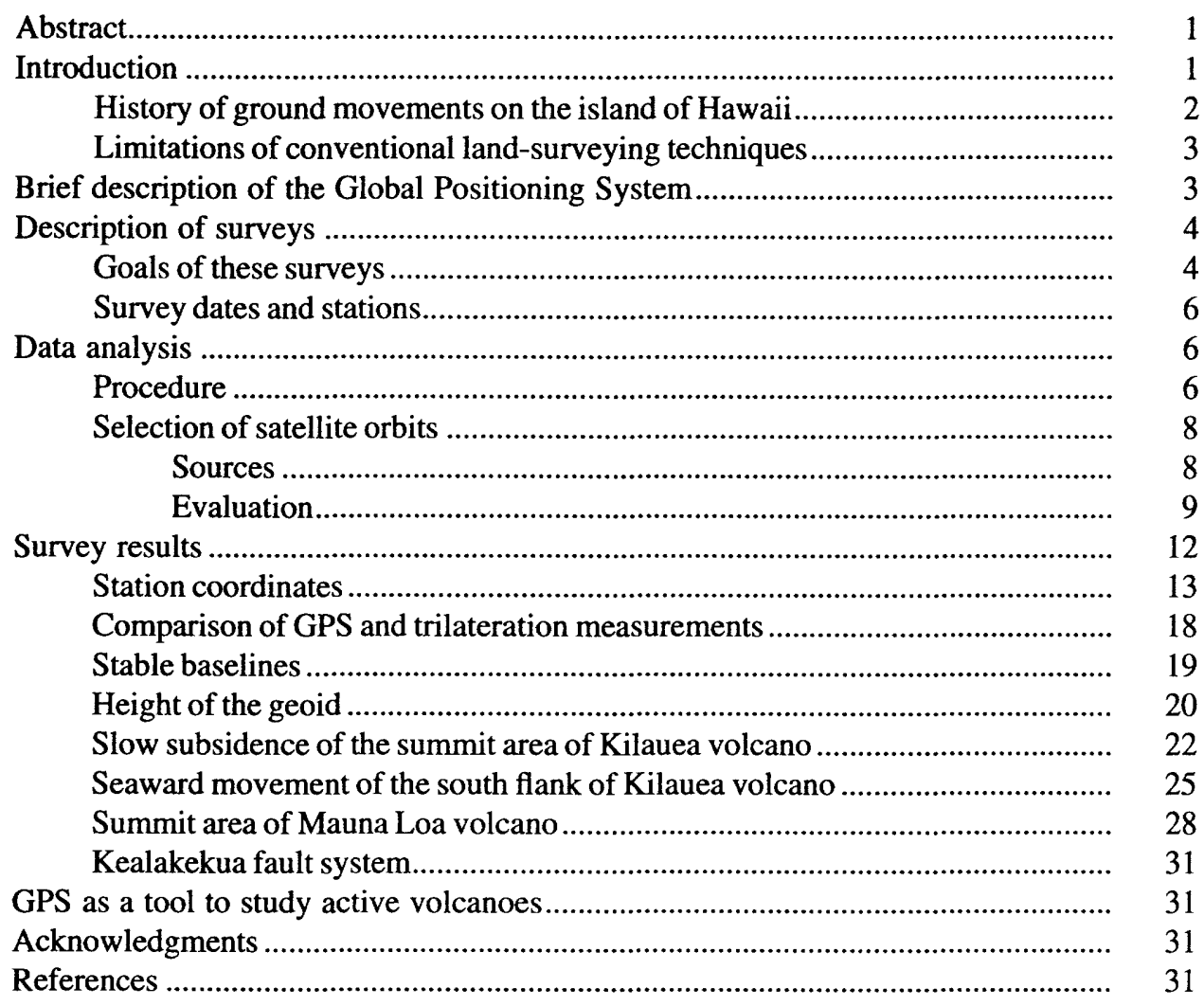

\section{FIGURES}

1. Maps of the island of Hawaii, showing the five volcanoes and locations of the 47 sites surveyed using GPS...... 2

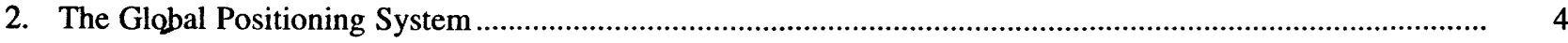

3. Using GPS to make measurements of relative position..............................................................................

4. Location of GPS stations on Kilauea and Mauna Loa volcanoes ................................................................ 5

5. The sites occupied during each GPS survey .................................................................................... 7

6. Annual measurements of the baseline distance between KOKEE PARK, Kauai, and LYMAN2 in Hilo, Hawaii.

7. Comparison of the 1987 position of LYMAN2 determined by broadcast orbits, orbits calculated using tracking data from NGS, and orbits from NSWC.

8. Comparison of station positions using orbits calculated using tracking data from NGS and orbits from NSWC

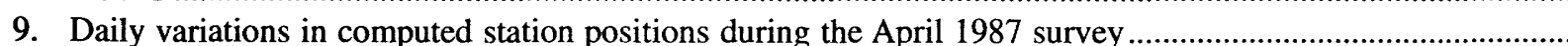

10. Comparison of trilateration and GPS measurements

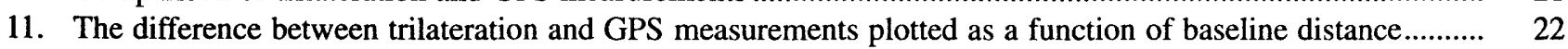

12. Comparison of changes in line lengths measured by trilateration and GPS .................................................. 22

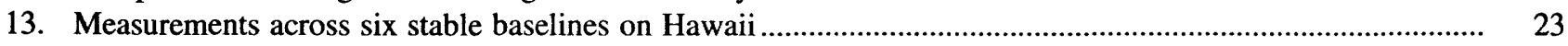

14. Geoid heights across the island of Hawaii, relative to LYMAN2 in Hilo ..................................................... 25

15. Slow subsidence of the summit area of Kilauea, indicated by results of leveling surveys ............................. 26

16. Slow subsidence and contraction of the summit area of Kilauea volcano, measured by GPS.......................... 26 
17. Horizontal displacement on Kilauea volcano and seismic activity between (1) April 1987 and August 1988 and (2) August 1989 and August 1990

18. Comparison of measured and computed horizontal displacement associated with the magnitude 6.1 earthquake on June 26, 1989

19. Comparison of measured and computed vertical displacement associated with the magnitude 6.1 earthquake on June 26,1989

20. GPS measurements in the summit area of Mauna Loa volcano.

21. GPS measurements along the southwest coast of Hawaii, the Kealakekua fault system

\section{TABLES}

1. Summary of GPS surveys in Hawaii

2. Values of constant parameters.

3. Coordinates of CIGNET stations

4. Position of GPS station LYMAN2

5. Daily variations of each GPS survey.

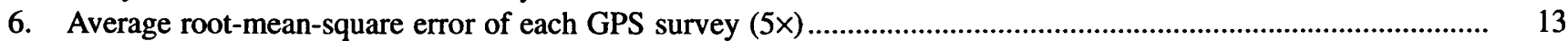

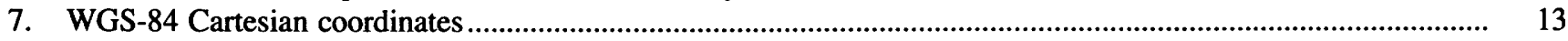

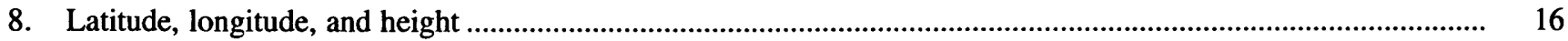

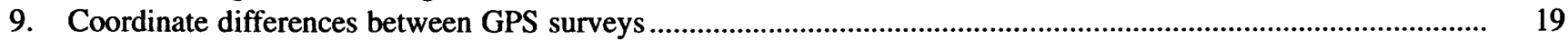

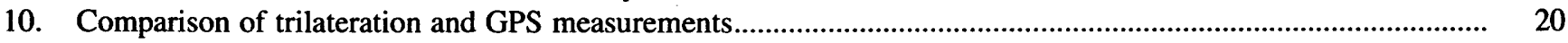

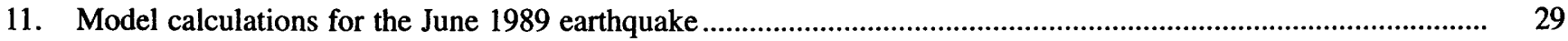




\title{
Global Positioning System Measurements on the Island of Hawaii from 1987 to 1990
}

\author{
By John J. Dvorak, Arnold T. Okamura, Michael Lisowski, William H. Prescott, and Jerry L. Svarc
}

\begin{abstract}
The Global Positioning System (GPS) is a satellite-based system that can be used to determine relative ground positions to a few centimeters or less over distances of tens to hundreds of kilometers. The system was used in Hawaii to measure the pattern of ground displacement associated with (1) the slow withdrawal of magma from the summit reservoir of Kilauea and (2) a magnitude 6.1 earthquake beneath the south flank of Kilauea on June 26, 1989.

GPS surveys were conducted on the island of Hawaii in April 1987, August 1988, August 1989, and August 1990. Approximately 40 ground stations were occupied during each survey. TI4100 radio receivers, which simultaneously receive a $P$-code and radio signals on two frequencies from four different satellites, were used during all surveys. Pcode is an encrypted time code from a satellite that allows unambiguous determination of satellite positions and empirical corrections for drift of each receiver-clock. Receipt of two radio frequencies allows a correction for propagation delays caused by the ionosphere.

We used satellite positions computed from orbits provided by the U.S. Naval Surface Weapons Center (NSWC). For our purpose, these positions were nearly the same as those computed from tracking data obtained from the worldwide system of GPS receivers operated by the National Geodetic Survey (NGS); the difference in relative ground positions on the island of Hawaii varied by a centimeter or less when we used orbits provided by NSWC or computed our own orbits from NGS tracking data. A similar comparison for the 548-km-long line between the GPS-tracking station on Kauai (KOKEE PARK) and our reference station at the Hilo airport (LYMAN2) showed the difference was $128 \mathrm{~mm}$ or less (0.23 part per million).

All measurements were processed using the Bernese software package. The internal consistency of each survey was estimated from the daily variation in computed station positions when the same baselines were measured on more than
\end{abstract}

Manuscript approved for publication April 4, 1994. one day. These daily variations were about five times the standard errors computed using the Bernese package. The least consistent surveys were conducted in August 1988 and August 1989, when radio signals from a key satellite were unavailable. In these cases, daily observing sessions lasted less than 4.4 hours, and four satellites could be tracked simultaneously for only 20 minutes. During surveys in April 1987 and August 1990, when daily observing sessions lasted up to 6.3 hours, the repeatability of station positions was $20 \mathrm{~mm}$ for horizontal components and $49 \mathrm{~mm}$ for vertical components. These values are as much as a factor of two larger than values reported for surveys of similar baseline lengths conducted in California. The lower repeatability of our surveys may be the result of our shorter observing sessions and of the location of our surveys outside the dense network of GPS-tracking stations on North America that were used to compute satellite orbits.

Our GPS measurements show that the summit area of Kilauea subsided at least $0.2 \mathrm{~m}$ between April 1987 and August 1990 . The subsidence, which was indicated also by repeated leveling surveys, was probably related to continued eruption of the volcano. During the four years spanned by our surveys, Kilauea erupted about $0.3 \mathrm{~km}^{3}$ of lava; 10 percent of the erupted volume can be accounted for by net subsidence of the summit area. We suggest that the other 90 percent was supplied by a deeper source that had no significant influence on ground displacement measured by GPS or other geodetic techniques.

The largest ground displacement recorded by GPS were associated with a magnitude 6.1 earthquake beneath the south flank of Kilauea on June 26, 1989. Horizontal displacements at sites located over the aftershock zone showed seaward displacement of the south flank of as much as $0.3 \mathrm{~m}$. Subsidence of as much as $0.25 \mathrm{~m}$ occurred near the eastern edge of the aftershock zone.

\section{INTRODUCTION}

The attempt to provide accurate predictions of volcanic eruptions has benefited from the measurement of ground 
displacement that results when magma moves up toward the ground surface. Though standard land-surveying techniques, such as leveling, triangulation and trilateration, have been used to record this displacement, these techniques require at least several days to complete and are restricted in the choice of survey sites. These limitations are partially overcome by a satellite-surveying technique that makes use of the Global Positioning System (GPS).

GPS uses a set of satellites and mobile ground-based receivers to determine ground positions. Though this system is still being developed, measurements made during the last few years show that relative three-dimensional positions on a centimeter-scale can be determined across baselines that range from tens to hundreds of kilometers. The speed, accuracy, and versatility of GPS make it an especially attractive as a tool to study active volcanoes.

We began using GPS in April 1987 on the active volcanoes in Hawaii, in particular on Kilauea volcano (fig. 1), one of the most active and thoroughly studied volcanoes in the world. The existence of extensive and frequently measured geodetic networks on Kilauea allows a comparison to be made of the amount of ground displacement measured by GPS and by other techniques.

\section{HISTORY OF GROUND MOVEMENTS ON THE ISLAND OF HAWAII}

Thomas A. Jaggar, Jr., one of the pioneers of the study of active volcanoes, began daily tilt measurements in the summit area of Kilauea in 1913. After two decades of measurements, Jaggar concluded that magma accumulated slowly in a shallow reservoir beneath the summit area (Jaggar and Finch, 1929). The accumulation was interrupted when an eruption occurred along one of two radial rift zones, and magma drained rapidly from the summit reservoir. Ground displacement caused by several dozen cycles of slow filling, each ending by a rapid withdrawal of magma and usually a rift-zone eruption, has now been recorded using a wide variety of techniques.

Beginning in the 1960s, these same techniques were extended to other areas of the island of Hawaii to search for other possible components of ground displacement. These efforts were quickly rewarded when measurements showed seaward displacement of the south flank of Kilauea, the portion of Kilauea that lies south of the two rift zones. The displacement was related to formation of new eruptive fissures (Swanson and others, 1976) and to a magnitude 7.2 earthquake beneath the south flank (Lipman and others, 1985). Measurements at adjacent Mauna Loa volcano showed gradual uplift, then rapid subsidence of the summit area associated with the 1984 eruption (Decker and others, 1983; Lockwood and others, 1987). Other measurements on Kilauea revealed a secondary magma reservoir along the east rift zone (Jackson and others, 1975), a migration of uplift centers in the summit area (Fiske and Kinoshita, 1969), the size of dikes that fed the 1971 and 1983 eruptive fissures (Dvorak and others, 1984; Dvorak, 1990), and the growth rate of the 1983 eruptive fissure (Okamura and others, 1988).

The rate and pattern of ground displacement of Kilauea have been used, along with studies of seismicity, gas emission, and petrology of erupted material, to propose a model

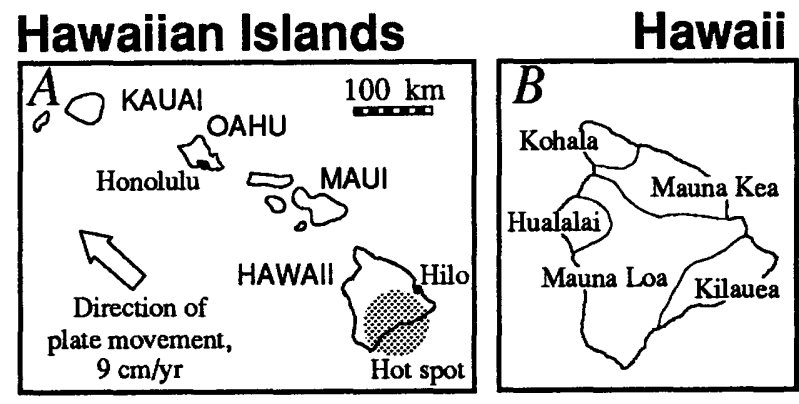

\section{GPS stations on Hawaii}

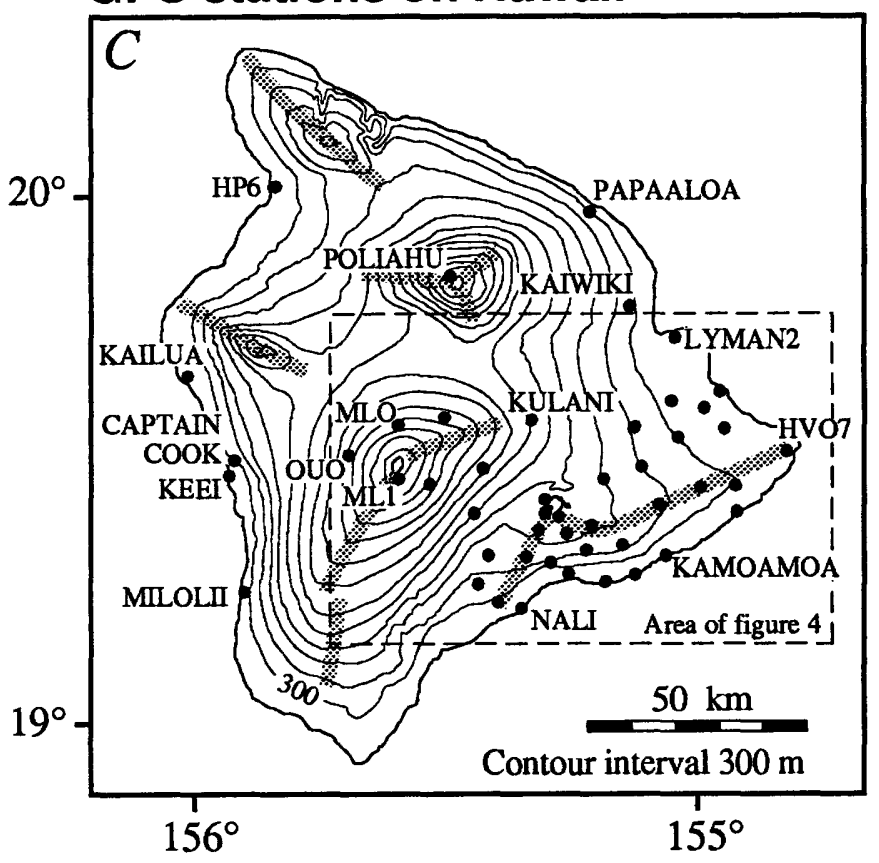

Figure 1. The island of Hawaii lies at southeast end of the Hawaiian island chain, over an anomaly in the mantle termed a hot spot $(A)$. The hot spot supplies magma to the active volcanoes, where it is erupted either in one of the summit areas or along one of the long rift zones radial to each summit area, indicated in map $C$ as broad shaded lines. Hawaii is composed of five volcanoes $(B)$ : Kohala is considered extinct; Mauna Kea and Hualalai last erupted 4,000 and 200 years ago, respectively; Mauna Loa last erupted in 1984; and Kilauea has been erupting since 1983. Most GPS stations, indicated as solid circles in map $C$, are located on Kilauea. Stations have also been located around the summit area and upper slopes of Mauna Loa and along the southwest coast of the island, the Kealakekua fault system. An enlargement of the area enclosed by the dashed rectangle in $C$ is shown in figure 4 . 
for the way Kilauea works (Eaton and Murata, 1960; Wright and Fiske, 1971; Decker, 1987; Dvorak and others, 1992; Tilling and Dvorak, 1993). As magma rises from the mantle into the summit reservoir located a few kilometers beneath the summit area, the surface of the volcano rises and distends. Magma accumulation is usually gradual, causing tens to hundreds of millimeters of ground displacement in the summit area over a period of several months to a year. When magma moves laterally from the summit reservoir along a conduit beneath a rift zone, the summit area subsides rapidly, dropping several hundred millimeters within a few hours. A dike that feeds an eruption begins to grow upward from a depth of a few kilometers either from magma stored in the summit reservoir or stored beneath a rift zone. By the time the dike has breached the surface and an eruption ensues, the dike may be a few kilometers high, several kilometers long, and a meter or more wide. A dike widens the rift zone and compresses the adjacent portion of the flank. Repeated injection of magma as dikes and compression of the flank cannot continue indefinitely. Eventually, the compression is relieved as a large earthquake, and the south flank of Kilauea suddenly moves seaward (Swanson and others, 1976).

\section{LIMITATIONS OF CONVENTIONAL LAND-SURVEYING TECHNIQUES}

The three strategies used at Kilauea to measure ground displacement are designed to record changes in (1) elevation, using a standard leveling technique, (2) horizontal strain by making trilateration measurements, or (3) ground inclination, called tilt.

The releveling of benchmarks to determine elevation changes is the best way to reveal a detailed pattern of vertical ground displacement if stations are closely spaced. Furthermore, vertical displacement of less than a part per million can be measured by using very simple equipment and field procedures (Dzurisin, 1992); a second-order leveling survey, which is usually achieved at Kilauea, has an accuracy of $10 \mathrm{~mm}$ over a distance of $25 \mathrm{~km}$. Major limitations are that the distance between stations must be easy to traverse, which usually requires the existence of a drivable road, and that a survey requires a few weeks to complete. These two limitations have restricted the use of leveling surveys to only a few volcanoes. One happens to be Kilauea, because the summit area is accessible by paved roads.

The second strategy makes use of electronic-distancemeasuring (EDM) instruments to measure changes in distance between pairs of benchmarks. Most EDM instruments now use a laser, which, depending on how the correction for atmospheric refraction is made, can be used to measure a horizontal distance to an accuracy of a few millimeters to a few centimeters over distances of $50 \mathrm{~km}$ or less. In order for these measurements to be made rapidly and over a broad area at Kilauea-rapid measurements are important because the surface of the volcano can move in several quick events in a month or less-temperature measurements of the atmosphere are made only at the two benchmarks, not over the entire path of the laser beam. Field tests show that endpoint temperature measurements limit the refraction correction to an accuracy of 3 or 4 parts per million (Decker and others, 1966), and so the distance between benchmarks separated by $10 \mathrm{~km}$ must change by more than 30 to $40 \mathrm{~mm}$ to be detected. Another disadvantage of trilateration measurements is that stations must be intervisible; thus, it is difficult to locate stations in rugged and steep terrain or in heavily forested areas, which are common around many volcanoes. To a degree, these limitations also apply to Kilauea. Few trilateration measurements have been made across the forested areas on the north flank and along portions of the east rift zone, and because of steep terrain, few measurements link activity along the rift zones and displacement of the south flank.

Though many different techniques have been developed to measure changes in ground tilt, all techniques have the problem of being able to record ground displacement over a short baseline. The difficulty is reduced where tilt changes are determined by measuring elevation changes between benchmarks separated by a few tens of meters. This technique, often called the "dry-tilt" method, has been used to record tilt changes as small as a few microradians (Yamashita, 1992). Because many volcanoes have steep slopes, this technique has had limited use. A further limitation of the dry-tilt method is that benchmarks must be very stable: A vertical change of $0.1 \mathrm{~mm}$ over a baseline of $30 \mathrm{~m}$ indicates a tilt change of 3 microradians.

In summary, the severest limitation of conventional land-surveying techniques is the choice of sites. Potential GPS stations, however, can be located almost anywhere, as long as a clear view of the sky is visible $20^{\circ}$ above the horizon and the station is not near metal structures, such as buildings and wire fences. Furthermore, GPS measurements can be made in more severe weather conditions than conventional techniques, and the radio receivers can operate unattended for days to months.

\section{BRIEF DESCRIPTION OF THE GLOBAL POSITIONING SYSTEM}

The GPS was designed by the U.S. Department of Defense as a satellite-based navigational system for real-time military applications. Military users can use GPS to determine absolute positions to within a few meters. Because radio signals from the satellites are encrypted and altered intentionally, civilian users are limited to an accuracy of absolute positions of $100 \mathrm{~m}$; however, radio signals received by two ground receivers operating in a differential mode can be combined to determine relative positions at 
the centimeter-level over distances of tens to hundreds of kilometers. It is in the high-precision, differential mode that GPS becomes a tool to measure surface displacement of geophysical interest.

Radio signals are transmitted from a constellation of satellites in 20,000-km-high orbits, giving an orbital period of 12 hours, and inclined $60^{\circ}$ to the equator (fig. 2). Each satellite transmits on two L-band frequencies (L1 on $1575.42 \mathrm{MHz}$ and $\mathrm{L} 2$ on $1227.60 \mathrm{MHz}$ ), which correspond to wavelengths of $0.19 \mathrm{~m}$ for $\mathrm{L} 1$ and $0.24 \mathrm{~m}$ for $\mathrm{L} 2$. Meter-level positioning is obtained by military users by receiving a special ranging code transmitted by each satellite, which enables the user to determine the distance to three or more satellites whose orbital positions are already known. Because errors are still present in satellite and receiver clocks, the range estimates are called pseudoranges, to distinguish them from the actual range distances between the satellites and a ground receiver.

In the differential mode, in which each pair of ground receivers observes simultaneously four or more satellites (fig. 3), we use pseudorange measurements to compute empirical corrections of drift of the receiver clocks. A high precision in positioning is obtained because of the submeter wavelength of the L-band signals and the use of carrier-phase measurements on the radio signals. By using phase measurements, the resulting distance between each satellite and receiver pair is ambiguous by an integer number of wavelengths. Because a large number of phase measurements is made, the phase ambiguities can be resolved, if we keep track of the number of cycles that occur between phase measurements. The use of two radio frequencies is needed to correct for the time delay as the radio signals pass through the ionosphere. Also there is a need to recompute satellite positions from observations taken from widely spaced sites when our surveys were conducted, because the satellite positions broadcast by the satellites at the time of the survey are

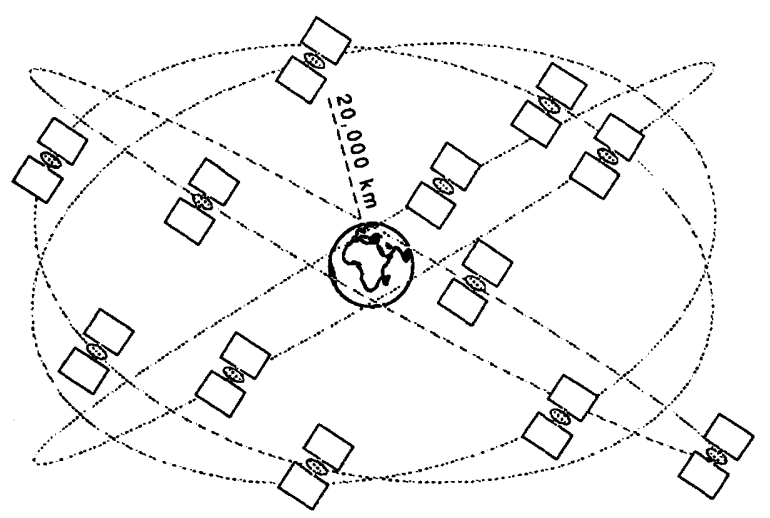

Figure 2. GPS consists of a network of NAVSTAR satellites in 20,000-km-high orbits. At this height, each satellite has an orbital period of about 12 hours. The future operation of 21 satellites will give 24-hour coverage over most areas of the world. extrapolations and may be further reduced in accuracy by the Department of Defense by a procedure known as selective availability. Additional details of how phase measurements are used to determine ground positions, as well as a more complete description of GPS, are given in Wells and others (1986) and Dixon (1991).

\section{DESCRIPTION OF SURVEYS}

Four GPS surveys were conducted on the island of Hawaii between April 1987 and August 1990 using dual radio-frequency TI4100 receivers. Forty-seven sites were occupied (figs. 1 and 4), of which many were occupied for only one day during each survey.

\section{GOALS OF THESE SURVEYS}

Frequent volcanic and seismic activity at Kilauea has made this volcano a proving ground for new techniques designed to measure magmatic activity in the upper crust. We had the following goals for using GPS in Hawaii.

- Evaluate GPS as a technique to measure slow crustal displacement in the mid-Pacific.-Many GPS surveys have been conducted on large continental land masses, often at latitudes of the continental U.S. or higher, such as Alaska (Beutler and others, 1987) and California and the Rocky Mountain States (Davis and others, 1989). The island of Hawaii is a different environment because it is located at low latitudes and is surrounded by ocean. High humidity may limit the accuracy of GPS in Hawaii and elsewhere in the subtropics and tropics.

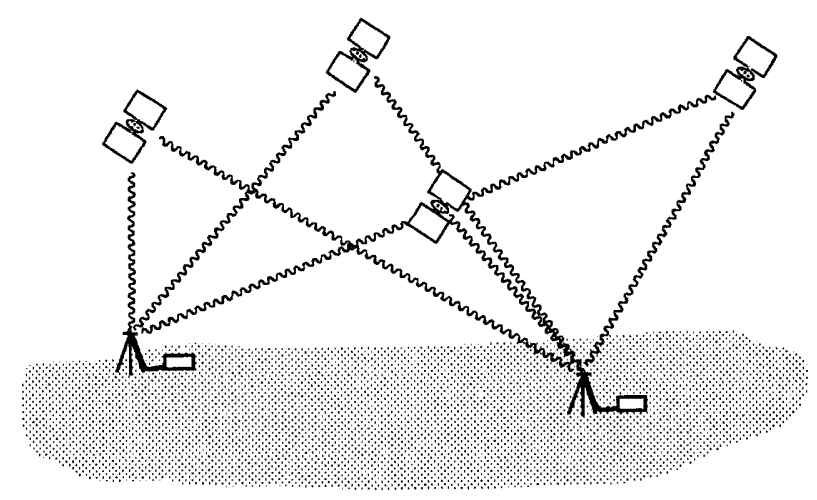

Figure 3. Though GPS was originally designed to determine absolute positions at meter level, station locations can be determined to centimeter level by making relative measurements between pairs of ground-based receivers. Each receiver records signals from the same subset of NAVSTAR satellites. Generally, four or more satellites must be observed simultaneously to determine three-dimensional position of each receiver and to make an empirical correction of drift of each receiver clock. 
- Compare measurements made using GPS and conventional land-surveying techniques. - Several decades of measurements of ground displacement have been made in many dynamic regions of the world, especially along fault systems and volcanic chains. Before GPS can take the role as the primary means to make these measurements, simultaneous measurements must be made using both GPS and established techniques to understand the peculiarities of old and new techniques and to test that the same rates of ground displacement are measured by both techniques.

- Carry out the initial Hawaiian surveys in the summit area and along the south flank of Kilauea, where the largest ground displacement is expected.-For more than three decades, intensive land surveys of Kilauea have identified several major components of ground displacement. We concentrated our initial effort in the summit area and along the south flank because these areas have had the largest amount and highest rates of ground displacement and are easily accessible. Thus, they are the most likely places for us to measure displacement.

- Extend later surveys to areas where conventional landsurveying techniques are difficult to conduct (the summit area and upper slopes of Mauna Loa and along the Kealakekua fault system). - Topography has limited, or prevented, the use of conventional techniques in two areas of special interest: the summit area and upper slopes of Mauna Loa and along the Kealakekua fault system on the southwest coast of the island. While Mauna Loa does not erupt as frequently as Kilauea, eruptions of Mauna Loa are usually more voluminous, by a factor of 10 (Macdonald and others, 1983), which suggests a larger magma reservoir associated with Mauna Loa. The remoteness of Mauna Loa makes it difficult to repeat leveling or trilateration measurements. Much is known about how Kilauea works, but infrequent eruptions of Mauna Loa have left a gap in a general understanding about Hawaiian volcanoes. The Kealakekua fault system offers an analogue to the Hilina fault system along the south flank of Kilauea, where two magnitude $>6.0$ earthquakes have occurred since 1975. During the last 40 years, three damaging earthquakes, all believed to be greater than magnitude 6.0, occurred along the Keala'iekua fault system. Furthermore, the earthquake risk has increased greatly along the west coast of Hawaii because of a rapid urban growth.

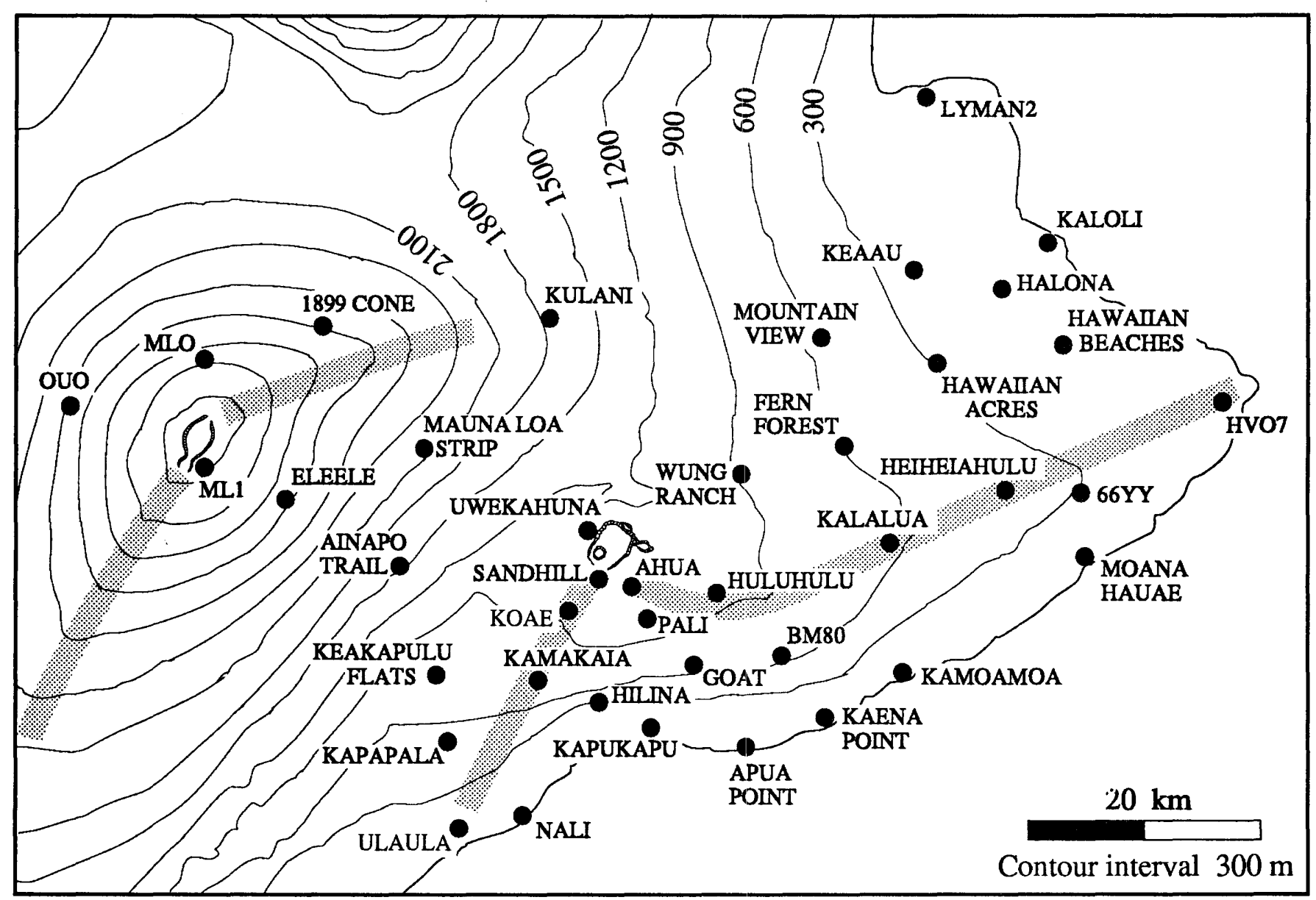

Figure 4. Most GPS stations are located on Kilauea, the most active Hawaiian volcano. Kilauea has been erupting along the east rift zone near KALALUA since 1983. The broad shaded lines are rift zones of Kilauea and the adjacent volcano Mauna Loa. 


\section{SURVEY DATES AND STATIONS}

A summary of the four GPS surveys is given in table 1. Each survey lasted 3 to 6 weeks. Because a complete set of satellites was not yet in operation at the time we conducted our surveys, our observing sessions were restricted to a duration of 6 hours or less and to time of day, which depended on the time of year of each survey. The first three surveys used only so-called "Block I" satellites. The last survey used Block I satellites as well as three "Block II" satellites, which have more precise clocks than Block I but may be subjected to "selective availability," meaning broadcast ephemerides, clock epochs, and clock frequencies may be altered.

The stations occupied by each survey and survey dates are shown in figure 5. Station names and coordinates will be presented later in the section "Survey Results."

Each receiver recorded data on magnetic cassette tape: a pseudorange and a phase measurement were recorded every 30 seconds for both L1- and L2-radio signals. At the end of an observing session, data were transferred from a tape onto two different Macintosh computer diskettes. At the end of a survey, one set of diskettes and data sheets, which recorded station name and antenna height and listed when satellites were observed, was sent to Menlo Park.

When available, tracking data from the Cooperative International GPS Network (CIGNET) was obtained from the National Geodetic Survey (Chin, 1992), as well as data in 1987 from a GPS receiver operated by the University of Texas at Austin (D. Carroll, oral commun., 1989)

\section{DATA ANALYSIS}

Except for the choice of satellite orbits, our procedure to process data followed that outlined by Davis and others (1989), using the Bernese software package developed by Beutler and others (1987).

\section{PROCEDURE}

The first step in processing was to make an empirical correction for drift of each receiver clock. The correction used pseudorange measurements to compute an initial time offset and a fifth-degree polynomial for each receiver on each day. This correction probably introduces no more than a 1-mm bias in station positions because we used doubledifference values of our phase measurements (Beutler and others, 1987). (No pseudorange measurements from satellite 8 were used because the quartz clock on this satellite was too inaccurate to be used to compute receiver-clock corrections. Some Block I satellites use the more accurate rubidium clocks; the other Block I and all Block II satellites use the highly accurate cesium clocks.)

For each observing session, single-difference values of phase measurements were computed for pairs of stations. Whenever possible, we used the station LYMAN2, located at the Hilo airport, as one station to compute single-difference values so that we would have common baselines year after year. For those days during the 1987 and 1988 surveys when LYMAN2 was not occupied, another reference station was chosen. The use of stations other than LYMAN2 is indicated in the lists of station coordinates.

Double-difference values of phase measurements were computed and used to identify integer cycle slips and bad points. Orbits computed from parameters provided by NSWC were used in the identification. First, the differences of L1-phase measurements were examined, then L2. When no more cycle slips or bad points could be detected either automatically by the program or visually by the operator, double differences were computed for L3, a linear combination of $\mathrm{L} 1$ and $\mathrm{L} 2$, and examined for integer cycle slips.

Table 1. Summary of GPS surveys in Hawaii.

\begin{tabular}{lcccc}
\hline \multicolumn{1}{c}{ Survey dates } & $\begin{array}{c}\text { Type of } \\
\text { receivers }\end{array}$ & $\begin{array}{c}\text { Number of } \\
\text { stations } \\
\text { occupied }\end{array}$ & $\begin{array}{c}\text { Duration of } \\
\text { observing } \\
\text { session } \\
\text { (hours) }\end{array}$ & Satellites observed \\
\hline Mar. 31 to Apr. 29, 1987 & TI4100 & 37 & 5.1 & $3,6,9,11,12,13$ \\
Aug. 12 to Sept. 2, 1988 & TI4100 & 35 & $6.0^{*}$ & $3,6,9^{*}, 11,12,13$ \\
Aug. 8 to Aug 25, 1989 & TI4100 & 44 & $4.8^{\dagger}$ & $3,6,9^{\dagger}, 11,12,13$ \\
July 31 to Aug. 17, 1990 & TI4100 & 35 & 6.3 & $3,6,9,12,16,18,20$ \\
\hline
\end{tabular}

\footnotetext{
* Satellite 9 was not usable from Aug. 17 to Aug. 30, 1988. During these dates, observing sessions were reduced to 4.2 hours.

†Satellite 9 was not usable from Aug. 17 to Aug. 22, 1989. During these dates, observing sessions were reduced to 4.4 hours.
} 
The next step was to compute station positions and possibly new satellite orbits if tracking data from CIGNET (Cooperative International GPS Network) were included. In these computations, we used the constant parameters listed in table 2, as well as measurements of the Earth's orientation and theoretical predictions of solid Earth tides. To minimize multipath error, we required elevation angles of satellites to be $20^{\circ}$ or higher (Dixon, 1991).
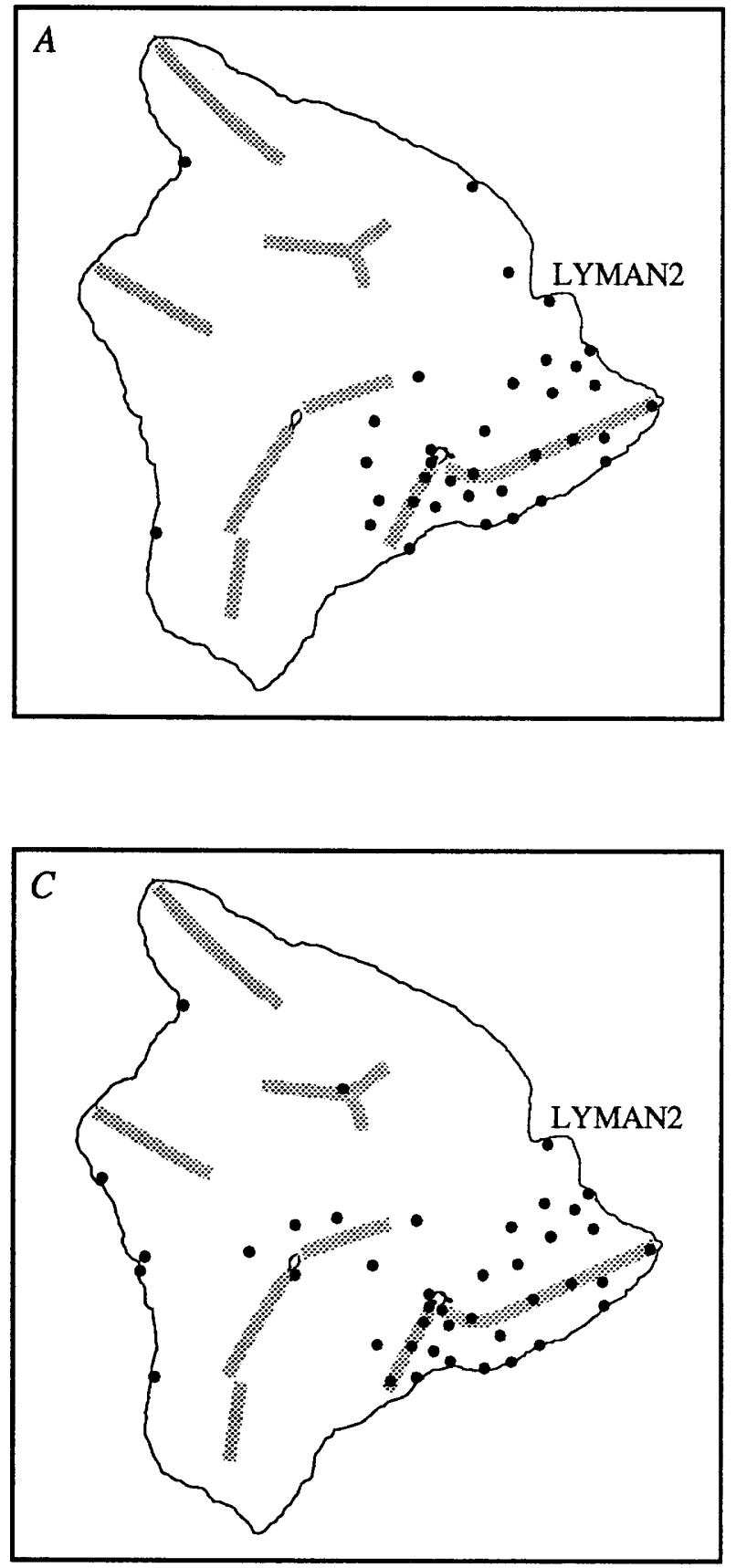

Figure 5. Stations occupied during each of the four annual GPS surveys. Rift zones indicated by shaded lines radial to the summit areas of each volcano. Stations names are shown in figures 1 and 4. WGS-84 station coordinates are listed in table 7. A, March 30 to April 29, 1987; B, August 12 to September 3, 1988; $C$, August 8 to 25,$1989 ; D$, July 31 to August $17,1990$.

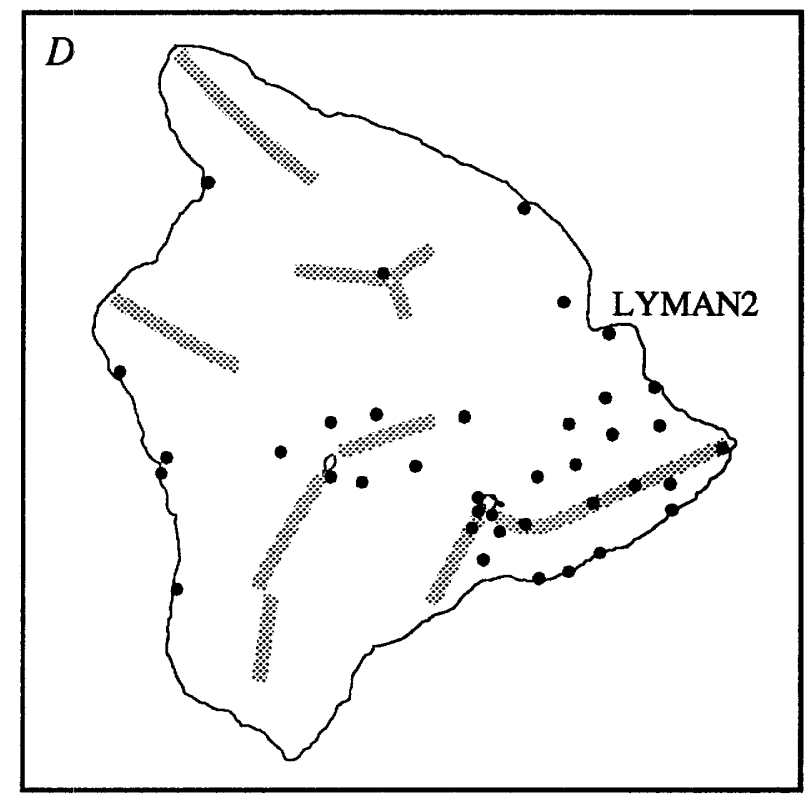

Once satellite orbits were selected, computation of a station position relative to the fixed position of LYMAN2 was a two-step process. The first step attempted to compute integer phase-cycle ambiguities from wide-lane values of the phase measurements, the so-called L5 phase values. Resolution of the phase ambiguity improves the horizontal position of a station, but has a slight effect on the vertical position (Dixon and others, 1991). Generally,

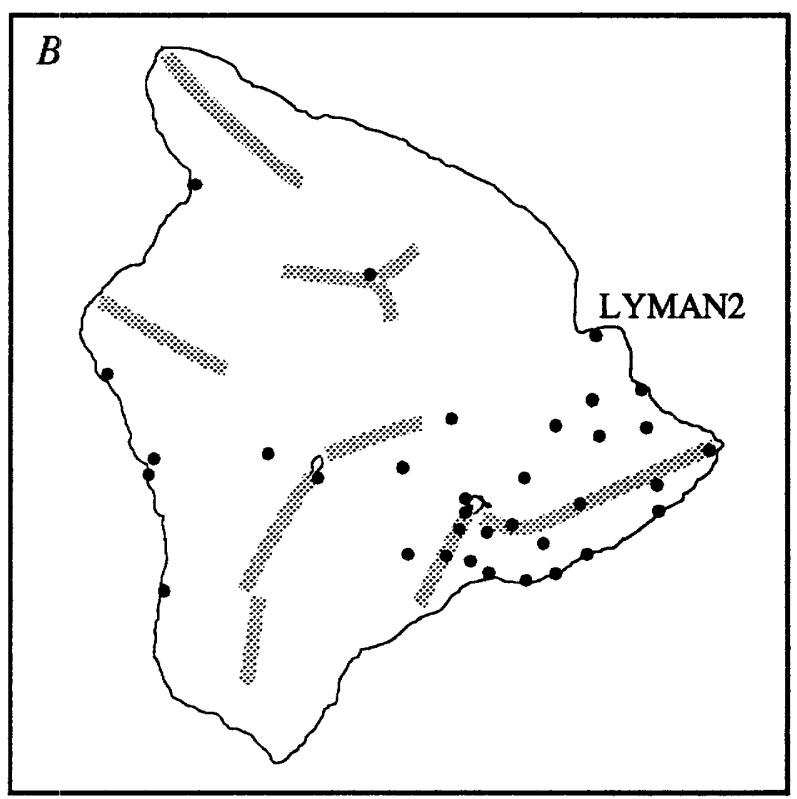


Table 2. Values of constant parameters.

\begin{tabular}{|c|c|c|c|}
\hline Constant & Value & & \\
\hline \multicolumn{4}{|l|}{ Physical constants: } \\
\hline Velocity of light- & \multirow{4}{*}{\multicolumn{3}{|c|}{$\begin{array}{l}299792458 \mathrm{~m} / \mathrm{s} \\
0.39860044 \times 10^{15} \mathrm{~m}^{3} / \mathrm{s}^{2} \\
1.3271250 \times 10^{20} \mathrm{~m}^{3} / \mathrm{s}^{2} \\
9027890 \times 10^{12} \mathrm{~m}^{3} / \mathrm{s}^{2}\end{array}$}} \\
\hline (Gravity constant $) \times($ Earth's mass) & & & \\
\hline (Gravity constant $) \times($ Sun's mass $)$ & & & \\
\hline (Gravity constant) $\times$ (Moon's mass) & & & \\
\hline \multicolumn{4}{|l|}{ Reference ellipsoid: } \\
\hline Equatorial radius of Earth - & \multirow{2}{*}{\multicolumn{3}{|c|}{$\begin{array}{l}6378137 \mathrm{~m} \\
1 / 298.257222\end{array}$}} \\
\hline Flattening of Earth- & & & \\
\hline Angular velocity of Earth & \multicolumn{3}{|l|}{$7292115.1467 \times 10^{-11} \mathrm{radians} / \mathrm{s}$} \\
\hline \multicolumn{4}{|l|}{ Eccentricity of TI4100 antenna: } \\
\hline L1-phase center - & \multirow{2}{*}{\multicolumn{3}{|c|}{$\begin{array}{l}0.227 \mathrm{~m} \text { above the base of the preamp } \\
0.212\end{array}$}} \\
\hline L2-phase center - & & & \\
\hline \multicolumn{4}{|l|}{ Satellite antenna offsets: } \\
\hline Block I satellites $3,6,9,12$, and 13 & $X=0.21$ & $\mathrm{Y}=0.00 \mathrm{~m}$ & $\mathrm{Z}=0.854 \mathrm{~m}$ \\
\hline Block II satellites $16,18,19$ and 20 & $X=0.2794 \mathrm{~m}$ & $\mathrm{Y}=0.00 \mathrm{~m}$ & $\mathrm{Z}=1.0229 \mathrm{~m}$ \\
\hline
\end{tabular}

we had good success in computing ambiguities, because most of our baselines were less $100 \mathrm{~km}$.

The second step was to calculate the L1- and L2ambiguities using the values from the L5 solution, then to compute final station positions by incorporating a model for the troposphere. The ionospheric delay was eliminated by a linear combination of the L1- and L2-phase measurements and the L1- and L2-carrier frequencies (Wells and others, 1986). Radio waves are nondispersive in the troposphere, so the tropospheric delay was determined by computing a single-parameter, zenith-delay model and by using an azimuthal-independent mapping function to compute the delay of any elevation angle (Davis and others, 1989). The following values at the height of the reference ellipsoid were used to compute the tropospheric delay: temperature $=18^{\circ} \mathrm{C}$, pressure $=1013.5$ millibars, and 50 percent humidity. This is the so-called "dry" correction, which assumes the troposphere is in hydrostatic equilibrium. A significant nonhydrostatic component may be caused by variations in content of water vapor, especially at the low subtropical latitudes of Hawaii. This problem is amplified on the island of Hawaii because a wide range of climatic conditions exists both laterally across the island (wet-windward versus dry-leeward sides) and over the 4-km elevation change between sea level and the summit areas of Mauna Loa and Mauna Kea. A correction for a nonhydrostatic component, the so-called "wet" correction, can be made if simultaneous measurements are made of water-vapor content during a GPS survey (Ware and others, 1986); however, water-vapor measurements are expensive and were not made in Hawaii. The result is probably a larger uncertainty of station positions for surveys conducted in the subtropics and tropics (Dixon and others, 1991).

\section{SELECTION OF SATELLITE ORBITS}

GPS can be used to determine precise station positions if satellite positions are well known. For example, at a distance of $20,000 \mathrm{~km}$, a satellite position must be known to within a few meters to attain centimeter-level accuracy in ground position across a 100-km baseline. This requires careful evaluation of the quality of orbits, which we evaluated by measuring changes along presumed stable baselines.

\section{SOURCES}

We considered three sources of satellite orbits: (1) positions broadcast by the satellites at the time of each survey, (2) orbits provided by the Naval Surface Weapons Center (NSWC) and (3) our own improved orbits using tracking data supplied by National Geodetic Survey from CIGNET.

Both L1- and L2-radio signals are modulated with a data stream that includes an orbital ephemeris of each satellite. Each ephemeris, which is broadcast on the hour, consists of the six osculating elements that uniquely define a position in space. A broadcast ephemeris is a predicted satellite trajectory computed from about one week of data collected from GPS stations operated by the Department of Defense (Wells and others, 1986). A new ephemeris is sent to a satellite at least once a day, though 6-hour updates are sent occasionally. Because these broadcast ephemerides are predicted satellite orbits, they are not adequate to determine precise ground positions, except for short baselines-that is, baselines less than $15 \mathrm{~km}$ in length. For this reason, we used broadcast ephemerides only to compute approximate 
Table 3. Coordinates of CIGNET stations.

[Values provided by National Geodetic Survey (Chin, 1992, and written communication)]

\begin{tabular}{lrrrr}
\hline & $X$ & & & \\
& & & & Receiver \\
\hline April 1987: & & & & \\
Austin, Tex. & -743773.949 & -5460643.710 & 3200347.492 & TI4100 \\
Kokee Park, Ha. & -5543817.052 & -2054588.402 & 2387854.185 & TI4100 \\
Mojave, Calif. & -2356214.416 & -4646733.924 & 3668460.609 & TI4100 \\
Westford, Mass. & 1492233.223 & -4458091.535 & 4296045.911 & TI4100 \\
August 1988: & & & & \\
Kokee Park, Ha. & -5543818.046 & -2054583.269 & 2387857.553 & TI4100 \\
Mojave, Calif. & -2356214.438 & -4646733.930 & 3668460.620 & TI4100 \\
Richmond, Fla. & 961318.469 & -5674057.739 & 2740565.215 & TI4100 \\
Westford, Mass. & 1492233.228 & -4458091.550 & 4296045.925 & TI4100 \\
August 1989: & & & & \\
Kokee Park, Ha. & -5543818.046 & -2054583.269 & 2387857.553 & TI4100 \\
Mojave, Calif. & -2356215.619 & -4646736.395 & 3668456.424 & MiniMac \\
Richmond, Fla. & 961319.516 & -5674075.349 & 2740538.919 & MiniMac \\
Westford, Mass. & 1492233.301 & -4458088.267 & 4296047.992 & MiniMac \\
\hline
\end{tabular}

station positions, which we can compare with a final station position computed using other satellite orbits if that station position deviated from our other estimates. In this way, we identified possible problems that occurred in computing our own orbits or in orbits obtained from NSWC.

Precise satellite ephemerides are provided by NSWC several weeks after data has been received at a worldwide network of nine or more tracking stations. We use the NSWC ephemerides to compute satellite positions by straightforward integration, taking into account gravitational attraction of Earth, Sun, and Moon; a tenth-order and -degree model of Earth's gravitational field, called GEM10 (Lerch and others, 1979); solar radiation pressure; and a force on a satellite called the y-bias factor, which presumably is caused by thermal radiation of the satellite or misaligned solar panels (Schultz and others, 1990). The resultant integration, which is performed over an 8- to 56hour period, depending on the number of successive days a station was occupied, is used to compute a new set of osculating elements and a single parameter for solar radiation pressure and another parameter for the $y$-bias factor.

As a third source, we computed our own improved orbits using data collected by CIGNET tracking stations. Type of receiver and location and type of antenna often changed during the years of our four surveys (Chin, 1992). As a result, different coordinates and different combinations of CIGNET stations were used during our first three surveys (table 3). (No orbits were computed for the last survey because the receiver at Kokee Park, Kauai, did not track satellites at the same time of day that our 1990 survey was conducted.) Most station coordinates listed in table 3, taken from a list of station coordinates and offsets listed in Chin (1992), are the positions of the L1-phase center expressed in the World Geodetic System 1984 (WGS-84), a terrestrial Earth-centered reference frame tied to the inertial coordinate system of the satellites (Wells and others, 1986). (In
WGS-84, the $\mathrm{X}$-axis passes through the intersection of the Greenwich meridian and the equatorial plane; the Z-axis passes through the average position of Earth's rotational pole for the 1984 epoch; and the Y-axis is orthogonal to the other two axes so that a right-handed coordinate system is formed.) The exceptions were the 1987 coordinates of Austin and Kokee Park. The station coordinate for Austin was provided by M. Chin (written commun., 1989) from measurements made in January 1987. From March 28 to April 12,1987 , the GPS antenna at Kokee Park was at a temporary location at the WVRM monument (M. Chin, written commun., 1989). We have compared all 1987 coordinates obtained from NGS and coordinates in a reference frame called SV5 provided by M. Murray (written commun., 1990). The Y- and Z-coordinates of the NGS and SV5 reference frames are all within $0.2 \mathrm{~m}$. The $\mathrm{X}$-coordinates are biased an average of $0.371 \mathrm{~m}$; after subtraction of this average value, the $\mathrm{X}$-coordinates of all four stations listed in table 3 for 1987 are within $0.034 \mathrm{~m}$ for the two reference frames. Baselines computed with broadcast and precise ephemerides show the latter to be more accurate (such as, Remondi and Hofmann-Wellenhof, 1990) because the precise ephemerides were computed from actual tracking of the satellites and, unlike the broadcast ephemerides, were not a prediction of satellite positions. We computed similar three-dimensional positions of baselines using satellite orbits provided by NSWC and orbits computed by ourselves from CIGNET tracking data. As will be shown in the next subsection, these positions were offset $0.3 \mathrm{~m}$ from positions computed from broadcast orbits.

\section{EVALUATION}

We evaluated satellite orbits three ways: (1) the ability to determine the three-dimensional position of the station 
LYMAN2 relative to KOKEE PARK, both by a comparison of annual determinations and during several single-day measurements during the 1987 surveys, (2) the variation in computed station positions using NSWC orbits and our own improved orbits, and (3) daily variations in station positions computed during each survey. A fourth means, which will be presented in the next section, compared annual determinations of station positions across what we expect are stable baselines on the island of Hawaii.

Annual determinations of the position of LYMAN2 are listed in table 4, using either NSWC orbits or our improved orbits and expressed in WGS-84. The values shown in table 4 were the result of multiday calculations. For 1987, the values were the average of two multiday determinations, from April 1 to 4 and from April 5 to 8 . For 1988, the values determined from NSWC orbits were from April 13 to 16, from April 19 to 20, from April 24 to 26, and from April 28 to 31; the values determined from our computed orbits using CIGNET data were calculated from April 13 to 16 . For 1989 , only values determined from NSWC orbits are given, averaged from values determined from April 8 to 11 and from April 23 to 25; the loss of satellite 9 in August 1989 prevented us from computing an improved orbit. No positions for LYMAN2 were deter- mined for 1990 because the Trimble GPS receiver at KOKEE PARK did not track simultaneously the same satellites we were tracking on the island of Hawaii.

The bottom of table 4 lists a conversion of WGS- 84 coordinates to latitude, longitude, and height above a reference ellipsoid. Also given is the baseline distance between LYMAN2 and the 1987 position of KOKEE PARK. The largest variations of the east-west and vertical components are about $0.1 \mathrm{ppm}$ for the $548-\mathrm{km}$-long line between KOKEE PARK and LYMAN2; the variation of the northsouth component is $0.26 \mathrm{ppm}$. In 1987 and 1988, NSWCderived positions and our improved-orbit positions are within several centimeters for longitude and height, but unexplainably high for latitude. The annual determinations of the baseline length are shown in figure 6 .

For 1987 data, we also computed the position of LYMAN2 from single-day data to check the amount of daily scatter. The results of our single-day analyses are compared with the multiday values in figure 7 . Each symbol represents a singleday value of each component relative to the average value determined from multiday inversions using NSWC orbits. For comparison, we also show the average values determined from multiday inversions using our improved orbits and broadcast orbits. As reported by many researchers, such as

Table 4. Position of GPS station LYMAN2.

\begin{tabular}{|c|c|c|c|c|c|c|c|}
\hline & \multicolumn{3}{|r|}{$\mathbf{x}$} & \multicolumn{2}{|r|}{$\mathrm{Y}$} & \multicolumn{2}{|r|}{$\mathrm{z}$} \\
\hline $\begin{array}{l}\text { April } 1987 \\
\text { NSWC orbits } \\
\text { Calculated orbits }\end{array}$ & \multicolumn{3}{|r|}{$\begin{array}{l}-5445971.060 \mathrm{~m} \\
-5445971.143\end{array}$} & \multicolumn{2}{|r|}{$\begin{array}{l}-2533159.910 \mathrm{~m} \\
-2533159.923\end{array}$} & \multicolumn{2}{|c|}{$\begin{array}{l}2138839.199 \mathrm{~m} \\
2138839.162\end{array}$} \\
\hline $\begin{array}{l}\text { August } 1988 \\
\text { NSWC orbits } \\
\text { Calculated orbits }\end{array}$ & \multicolumn{3}{|r|}{$\begin{array}{l}-5445971.112 \\
-5445971.082\end{array}$} & \multicolumn{2}{|r|}{$\begin{array}{r}-2533159.895 \\
-233159.900\end{array}$} & \multicolumn{2}{|c|}{$\begin{array}{l}2138839.127 \\
2138839.252\end{array}$} \\
\hline \multirow[t]{2}{*}{$\begin{array}{l}\text { August } 1989 \\
\text { NSWC orbits } \\
\text { Largest variation }\end{array}$} & \multicolumn{3}{|r|}{$\begin{array}{r}-5445971.105 \\
0.083 \mathrm{~m}\end{array}$} & \multicolumn{2}{|r|}{$\begin{array}{r}-2533159.915 \\
0.028 \mathrm{~m}\end{array}$} & \multicolumn{2}{|c|}{$\begin{array}{r}2138839.110 \\
0.142 \mathrm{~m}\end{array}$} \\
\hline & & & Latitude & & Longitude & Height ${ }^{1}$ & Distance $^{2}$ \\
\hline $\begin{array}{l}\text { April } 1987 \\
\text { NSWC orbits } \\
\text { Calculated orbits } \\
\text { Difference }\end{array}$ & $\begin{array}{l}19^{\circ} \\
19\end{array}$ & $\begin{array}{l}43 \\
43\end{array}$ & $\begin{array}{c}21.90783 " \\
21.90581 \\
0.062 \mathrm{~m}\end{array}$ & $\begin{array}{l}-155^{\circ} \\
-155\end{array}$ & $\begin{array}{c}17.26675^{\prime \prime} \\
17.26755 \\
0.029 \mathrm{~m}\end{array}$ & $\begin{array}{l}26.030 \mathrm{~m} \\
26.093 \\
0.063 \mathrm{~m}\end{array}$ & $\begin{array}{l}548281.852 \mathrm{~m} \\
548281.866 \\
0.014 \mathrm{~m}\end{array}$ \\
\hline $\begin{array}{l}\text { August } 1988 \\
\text { NSWC orbits } \\
\text { Calculated orbits } \\
\text { Difference }\end{array}$ & $\begin{array}{l}19^{\circ} \\
19\end{array}$ & $\begin{array}{l}43^{\prime} \\
43\end{array}$ & $\begin{array}{c}21.90519^{\prime \prime} \\
21.90929 \\
0.126 \mathrm{~m}\end{array}$ & $\begin{array}{l}-155^{\circ} 3 \\
-1553\end{array}$ & $\begin{array}{c}17.26798^{\prime \prime} \\
17.26739 \\
0.017 \mathrm{~m}\end{array}$ & $\begin{array}{l}26.044 \mathrm{~m} \\
26.063 \mathrm{~m} \\
0.019 \mathrm{~m}\end{array}$ & $\begin{array}{c}548281.863 \mathrm{~m} \\
548281.816 \\
0.047 \mathrm{~m}\end{array}$ \\
\hline $\begin{array}{l}\text { August } 1989 \\
\text { NSWC orbits }\end{array}$ & $19^{\circ}$ & $43^{\prime}$ & $21.90465^{\prime \prime}$ & $-155^{\circ} 3$ & $17.26726^{\prime \prime}$ & $26.040 \mathrm{~m}$ & $548281.890 \mathrm{~m}$ \\
\hline Largest variation & & & $\begin{array}{l}0.00318 " \\
0.143 \mathrm{~m}^{\prime \prime} \\
0.26 \mathrm{ppm}^{3}\end{array}$ & & $\begin{array}{l}0.00123 " \\
0.036 \mathrm{~m}^{\prime \prime} \\
0.07 \mathrm{ppm}^{3}\end{array}$ & $\begin{array}{l}0.063 \mathrm{~m} \\
0.11 \mathrm{ppm}^{3}\end{array}$ & $\begin{array}{l}0.074 \mathrm{~m} \\
0.14 \mathrm{ppm}^{3}\end{array}$ \\
\hline
\end{tabular}

\footnotetext{
${ }^{1}$ Height above reference ellipsoid.

${ }^{2}$ Distance between LYMAN2 and the 1987 position of KOKEE PARK, Ha.

${ }^{3}$ Based on the $548-\mathrm{km}$ distance between KOKEE PARK and LYMAN2.
} 
Remondi and Hofmann-Wellenhof (1990), similar station positions are computed using orbits derived from actual tracking data, as opposed to the broadcast orbits, which are predicted satellite positions and which have larger biases. Within the daily scatter shown in figure 6, NSWC and our improved orbits yield the same position for LYMAN2-that is, a position within $0.2 \mathrm{ppm}$ or less.

For 1987 data, we compared station positions on the island of Hawaii determined from NSWC and our improved orbits. In this comparison, we computed improved orbits for only the first two weeks of the survey, from March 31 to April 11, when a GPS station was operated at KOKEE PARK. For these two weeks, 21 comparisons were possible, using baseline lengths that varied from 11 to $108 \mathrm{~km}$ (fig. 8). If we include all baselines, the apparent changes in north/ south and east/west positions both have root-mean-square values of $5 \mathrm{~mm}$. If we include only baselines shorter than 80 $\mathrm{km}$, the root-mean-square values were 2 and $3 \mathrm{~mm}$ for north/south and east/west positions, respectively. (The two baselines longer than $80 \mathrm{~km}$ were across the entire island, LYMAN2 to HP6 and LYMAN2 to MILOLII.) The rootmean-square value of vertical positions was $27 \mathrm{~mm}$ for all baselines, $12 \mathrm{~mm}$ for baselines shorter than $80 \mathrm{~km}$. In summary, for stations on the island of Hawaii, the inversion scheme in the Bernese software using either NSWC orbits or our improved orbits from CIGNET tracking data yields horizontal positions to a centimeter or less and vertical positions to within five centimeters. We could not always compute an improved orbit because the CIGNET tracking stations did not always track the same satellites as we did during our surveys, especially when satellite 9 was unavailable during the 1988 and 1989 surveys. Orbits were always available from NSWC, so NSWC orbits were used to process all four Hawaiian GPS surveys. The remaining results in this report were derived solely by using NSWC orbits.

Because the duration of daily observing sessions varied from 4.2 to 6.3 hours and because we lost satellite 9 midway through the 1988 and 1989 surveys (table 1), we must use an independent means to estimate the accuracy of each survey. This was done by computing root-mean-square values
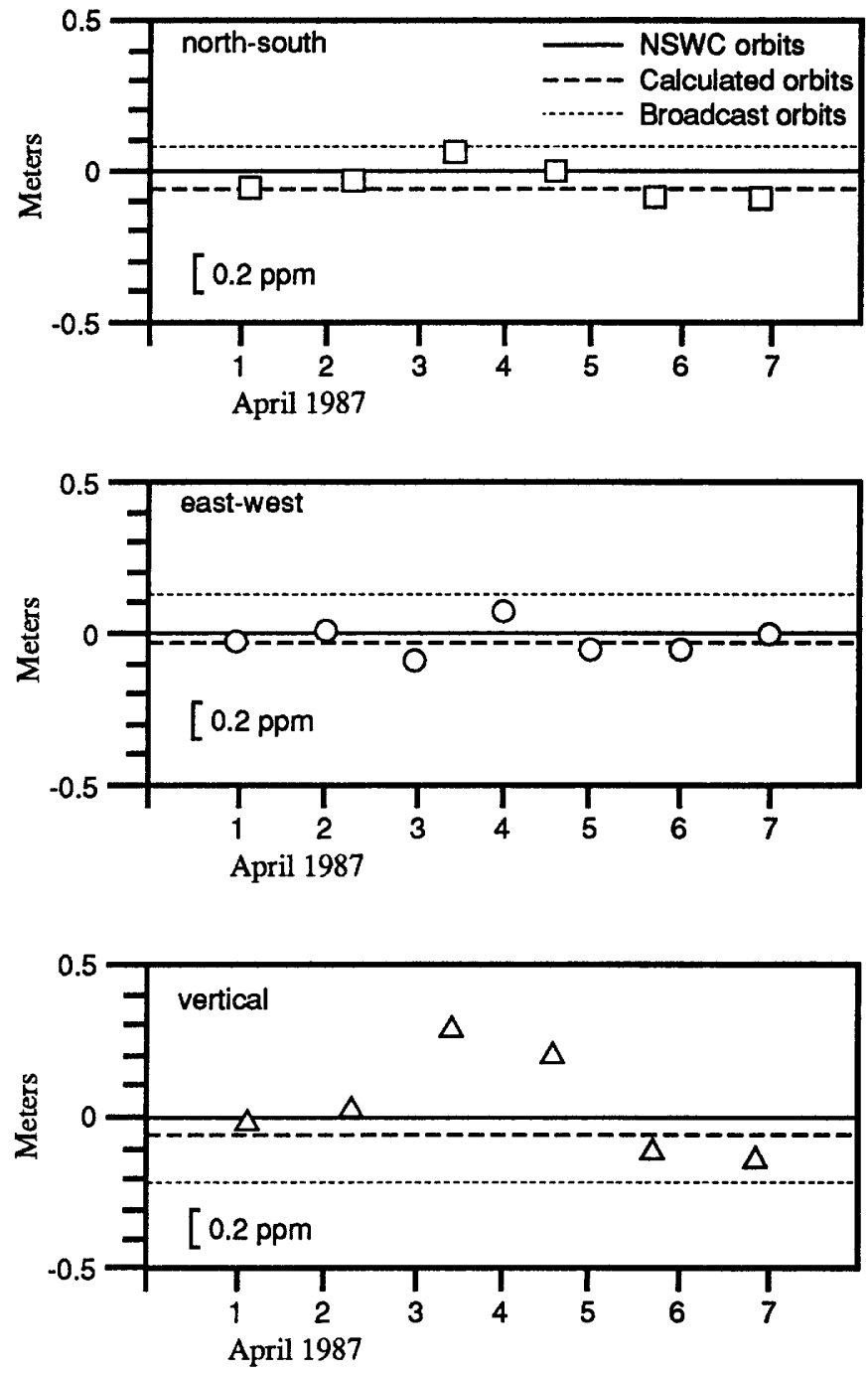

Figure 7. Comparison of daily and multiday determinations of the position of LYMAN2. The three components of position are shown with respect to the average position of LYMAN2 determined from NSWC orbits. Daily determinations are shown as symbols.

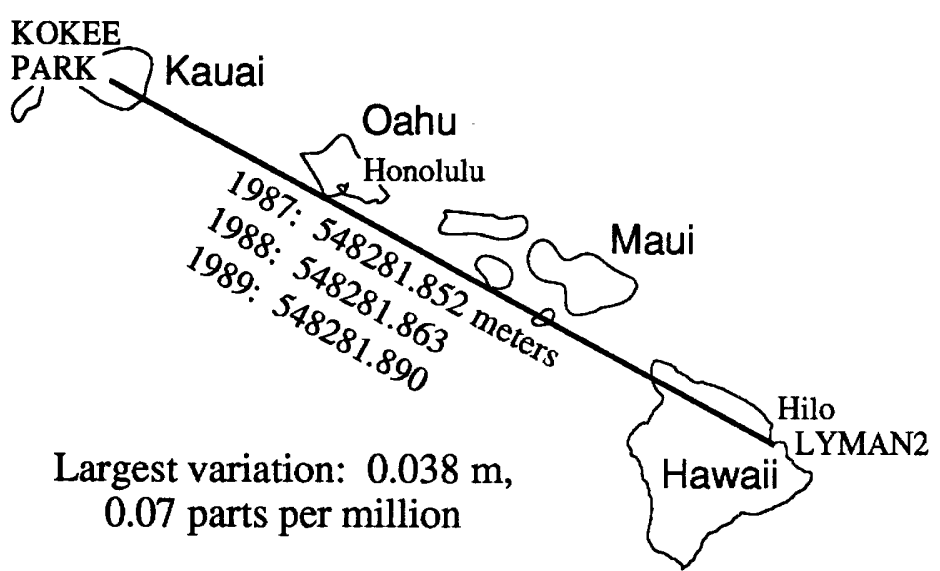

Figure 6. Annual measurements of the distance between KOKEE PARK and LYMAN2. Largest variation was $0.038 \mathrm{~mm}$, which, for this $548-\mathrm{km}$-long line, corresponds to 0.07 parts per million. 

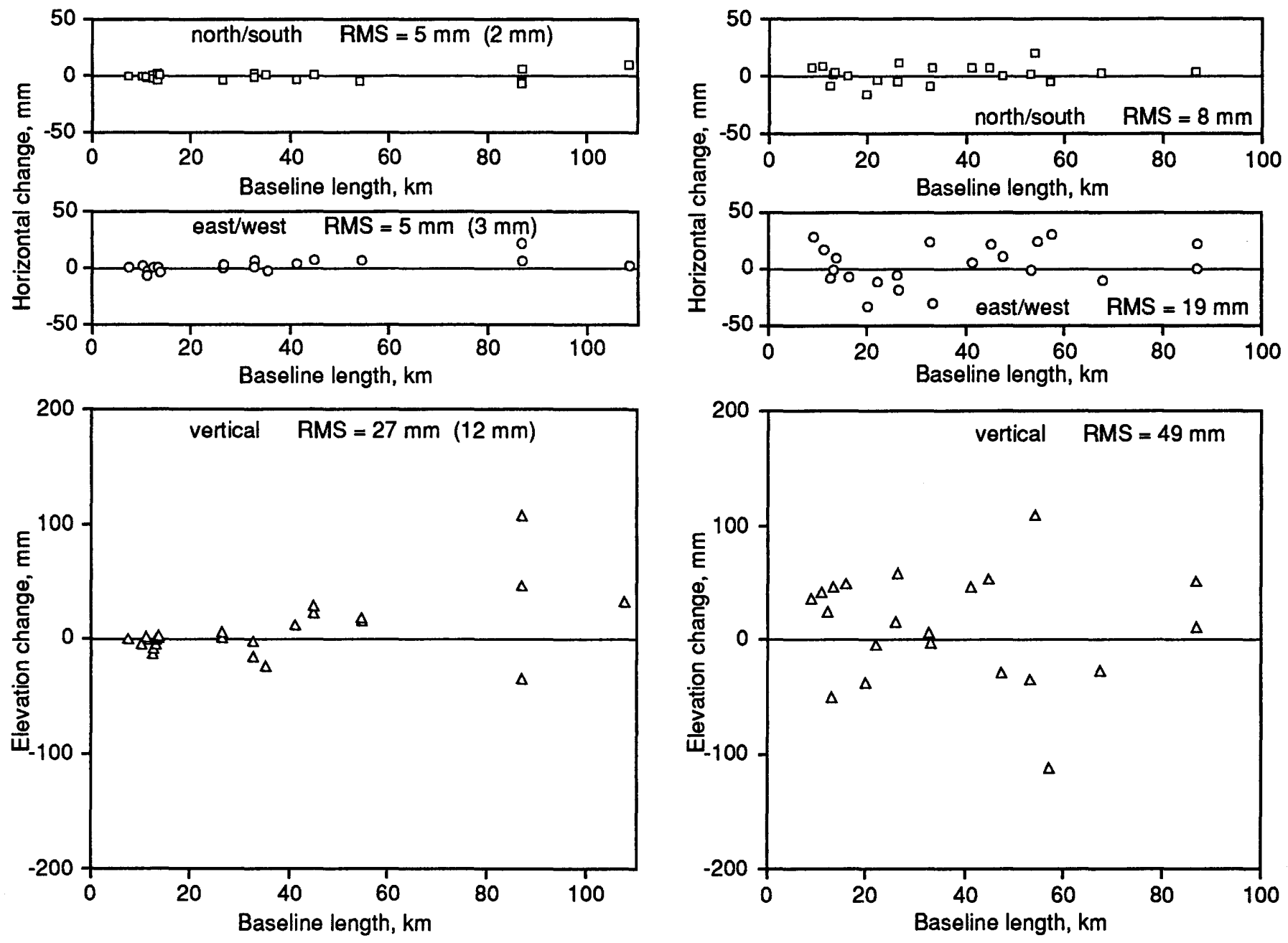

Figure 8. Differences in station positions determined using NSWC orbits and orbits calculated using tracking data from CIGNET. At top of each diagram is the root-mean-square value for all measurements; the numbers in parentheses are root-mean-square values for baselines shorter than $80 \mathrm{~km}$.

for horizontal and vertical components from the daily variation for baselines measured more than once during a survey. For the 1987 survey, repeated measurements were made of 21 baselines. The apparent changes in station positions are shown in figure 9. The north/south and east/west components had root-mean-square values of 8 and $19 \mathrm{~mm}$, respectively. The vertical component was $49 \mathrm{~mm}$. These values are probably too pessimistic because they are based on single observing sessions. Some final station positions, to be given in the next section, are based on multiday analyses, which are more accurate than single-day analyses (for example, see Davis and others, 1989). The repeatability of each survey is listed in table 5, which is based on apparent changes in station positions for baselines repeated during a survey.

The Bernese software computes a standard error for each of the three components of position. Davis and others $(1989$, p. 13,639$)$ found that these standard errors "were too

Figure 9. Daily variations in computed station positions using NSWC orbits. The root-mean-square value for each component is given in each diagram.

small by a factor of 3 to 5 to explain long-term variations." We arrived at a similar conclusion when we compared standard errors and daily variations for each survey listed in table 5. To illustrate, for each survey we computed the average standard error of each component and multiplied the result by five. The factor of five increased the standard errors to about the same values determined from our analysis of daily variations (compare tables 5 and 6 ). Later in this paper, where we report specific uncertainties of a station position, those uncertainties were determined by multiplying the standard error of each component by five.

\section{SURVEY RESULTS}

In this section, the position of each station for each annual survey is given in WGS-84 coordinates and in latitude, longitude, and height. Some coordinates are used to 
Table 5. Daily variations of each GPS survey.

\begin{tabular}{lccll}
\hline \multicolumn{1}{c}{ Survey } & $\begin{array}{c}\text { Number of } \\
\text { Comparisons }\end{array}$ & north/south & east/west & up/down \\
\hline April 1987 & 21 & $8 \mathrm{~mm}$ & $19 \mathrm{~mm}$ & $49 \mathrm{~mm}$ \\
August 1988 & 4 & 27 & 40 & 66 \\
August 1989 & 9 & 20 & 25 & 60 \\
August 1990 & 11 & 9 & 20 & 55 \\
\hline
\end{tabular}

Table 6. Average root-mean-square error of each GPS survey $(5 \times)$.

\begin{tabular}{lccc}
\hline \multicolumn{1}{c}{ Survey } & north/south & east/west & up/down \\
\hline April 1987 & $9 \mathrm{~mm}$ & $12 \mathrm{~mm}$ & $51 \mathrm{~mm}$ \\
August 1988 & 15 & 45 & 55 \\
August 1989 & 9 & 21 & 47 \\
August 1990 & 9 & 24 & 51 \\
\hline
\end{tabular}

compute baseline distances so that comparisons can be made between GPS and trilateration measurements made between several pairs of GPS benchmarks. We also examine the annual remeasurement of several stable baselines on the island of Hawaii so as to have yet another indication of the accuracy of our GPS surveys. A short subsection will report the geoid heights determined across Hawaii by the difference between geometric heights computed from the 1989 GPS survey and orthometric heights measured by a 1989 leveling survey. The remainder of this section reports the GPS results for four areas on Hawaii: the summit area of Kilauea, the south flank of Kilauea, the summit area of Mauna Loa, and the southwest coast of the island along the Kealakekua fault system.

\section{STATION COORDINATES}

For each of our four annual surveys, station positions are listed in table 7 in terms of WGS-84 Cartesian coordinates and in table 8 in terms of latitude, longitude, and height

Table 7. WGS-84 Cartesian coordinates.

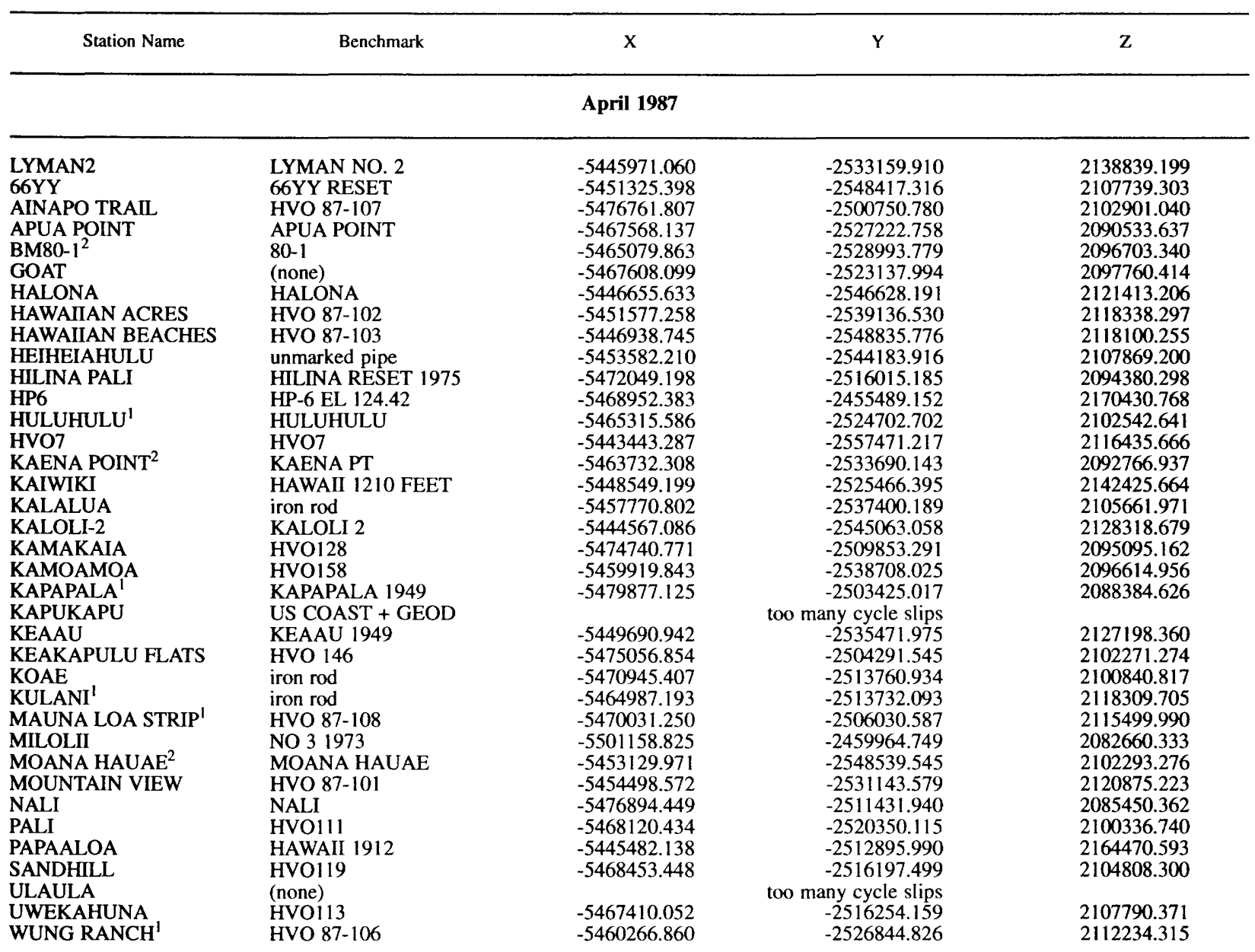


Table 7. WGS-84 Cartesian coordinates-Continued.

\begin{tabular}{|c|c|c|c|c|}
\hline Station Name & Benchmark & $\mathrm{x}$ & $\mathbf{Y}$ & $\mathbf{z}$ \\
\hline \multicolumn{5}{|c|}{ August 1988} \\
\hline LYMAN2 & LYMAN NO. 2 & -5445971.060 & -2533159.910 & 2138839.199 \\
\hline $66 \mathrm{YY}$ & 66YY RESET & -5451325.344 & -2548417.297 & 2107739.281 \\
\hline *APUA POINT & APUA POINT & -5467567.254 & -2527222.859 & 2090533.605 \\
\hline BM $80-1$ & $80-1$ & -5465080.020 & -2528993.892 & 2096703.340 \\
\hline *CAPTAIN COOK & HVO $88-12$ & -5491390.756 & -2455768.505 & 2114392.958 \\
\hline *HAWAIIAN ACRES & HVO $87-102$ & -5451577.189 & -2539136.473 & 2118338.281 \\
\hline *HAWAIIAN BEACHES & HVO 87-103 & -5446938.744 & -2548835.762 & 2118100.236 \\
\hline *HILINA PALI & HLINA RESET 1975 & -5472049.262 & -2516015.193 & 2094380.277 \\
\hline *HP6 & HP-6 EL 124.42 & -5468952.469 & -2455489.146 & 2170430.817 \\
\hline *HULUHULU & HULUHULU & -5465315.635 & -2524702.846 & 2102542.669 \\
\hline $\mathrm{HVO}^{3}$ & HVO7 & -5443443.246 & -2557471.171 & 2116435.634 \\
\hline KAENA POINT & KAENA PT & -5463732.443 & -2533690.202 & 2092766.894 \\
\hline KAILUA & HVO 88-11 & -5489953.972 & -2443731.460 & 2130483.489 \\
\hline *KALALUA & iron rod & -5457770.667 & -2537400.132 & 2105661.884 \\
\hline *KALOLI-2 & KALOLI 2 & -5444567.019 & -2545063.082 & 2128318.688 \\
\hline *KAMAKAIA & HVO128 & -5474740.772 & -2509853.226 & 2095095.101 \\
\hline KAMOAMOA $^{3}$ & HVO158 & -5459919.938 & -2538708.062 & 2096614.939 \\
\hline *KAPUKAPU & US COAST + GEOD & -5470259.728 & -2520715.707 & 2092292.353 \\
\hline $\mathrm{KEAAU}^{4}$ & KEAAU 1949 & -5449691.003 & -2535472.008 & 2127198.369 \\
\hline KEAKAPULU FLATS $^{5}$ & HVO 146 & -5475056.872 & -2504291.571 & 2102271.122 \\
\hline KEEI & KEEI NO BASE 1948 & -5492297.155 & -2454606.114 & 2112006.028 \\
\hline *KOAE & iron rod & -5470945.298 & -2513760.942 & 2100840.738 \\
\hline *KULANI & iron rod & -5464987.225 & -2513732.122 & 2118309.733 \\
\hline *MAUNA LOA STRIP & HVO $87-108$ & -5470031.158 & -2506030.527 & 2115499.937 \\
\hline *MILOLII & NO 31973 & -5501158.943 & -2459964.773 & 2082660.384 \\
\hline${ }^{*} \mathrm{MLI}^{6}$ & ML1 & -5482189.891 & -2487576.651 & 2111928.098 \\
\hline *MOANA HAUAE & MOANA HAUAE & -5453130.093 & -2548539.625 & 2102293.331 \\
\hline MOUNTAIN VIEW & HVO 87-101 & -5454498.531 & -2531143.567 & 2120875.216 \\
\hline *OUO & $76-16$ & -5483781.073 & -2476836.254 & 2116261.294 \\
\hline *PALI & HVO111 & -5468120.483 & -2520350.105 & 2100336.739 \\
\hline POLIAHU & HVO 88-14 & -5464796.210 & -2492640.467 & 2150664.398 \\
\hline SANDHILL & HVO119 & -5468453.371 & -2516197.525 & 2104808.228 \\
\hline ULAULA & (none) & & too many cycle slips & \\
\hline UWEKAHUNA & HVO113 & -5467410.125 & -2516254.206 & 2107790.329 \\
\hline *WUNG RANCH & HVO $87-106$ & -5460266.860 & -2526844.777 & 2112234.281 \\
\hline
\end{tabular}

August 1989

\begin{tabular}{|c|c|c|c|c|}
\hline LYMAN2 & LYMAN NO. 2 & -5445971.060 & -2533159.910 & 2138839.199 \\
\hline *1899 & 1899 & -5473028.975 & -2495131.859 & 2123112.472 \\
\hline $66 Y Y$ & 66YY RESET & -5451325.206 & -2548417.264 & 2107739.012 \\
\hline AHUA & HVO 114 & -5467762.194 & -2518810.862 & 2103350.702 \\
\hline APUA POINT & APUA POINT & -5467568.214 & -2527222.856 & 2090533.550 \\
\hline BM80-1 & $80-1$ & -5465079.968 & -2528993.943 & 2096703.241 \\
\hline CAPTAIN COOK & HVO 88-12 & -5491390.780 & -2455768.482 & 2114392.986 \\
\hline FERN FOREST & HVO 89-1 & -5458401.521 & -2531794.233 & 2111447.523 \\
\hline GOAT & (none) & & too many cycle slips & \\
\hline *HALONA & HALÓNA & -5446655.682 & -2546628.266 & 2121413.203 \\
\hline HAWAIIAN ACRES & HVO $87-102$ & -5451577.256 & -2539136.571 & 2118338.230 \\
\hline HAWAIIAN BEACHES & HVO $87-103$ & -5446938.791 & -2548835.809 & 2118100.191 \\
\hline HEIHEIAHULU & unmarked pipe & -5453581.821 & -2544183.836 & 2107868.654 \\
\hline HILINA PALI & HILINA RESET 1975 & -5472049.310 & -2516015.261 & 2094380.281 \\
\hline *HP6 & HP-6 EL 124.42 & -5468952.458 & -2455489.178 & 2170430.801 \\
\hline HULUHULU & HULUHULU & -5465315.541 & -2524702.753 & 2102542.539 \\
\hline HVO7 & HVO7 & -5443443.225 & -2557471.169 & 2116435.583 \\
\hline KAENA POINT & KAENA PT & -5463732.379 & -2533690.308 & 2092766.772 \\
\hline KALOLI-2 & KALOLI 2 & -5444567.061 & -2545163.049 & 2128318.653 \\
\hline KAMAKAIA & HVO128 & -5474740.739 & -2509853.306 & 2095095.133 \\
\hline KAMOAMOA & HVO158 & -5459919.888 & -2538708.170 & 2096614.736 \\
\hline KAPUKAPU & US COAST + GEOD & -5470259.819 & -2520715.914 & 2092292.421 \\
\hline KEAAU & KEAAU 1949 & -5449690.933 & -2535471.995 & 2127198.346 \\
\hline KEAKAPULU FLATS & HVO 146 & -5475056.844 & -2504291.566 & 2102271.243 \\
\hline KEEI & KEEI NO BASE 1948 & -5492297.052 & -2454606.041 & 2112006.005 \\
\hline${ }^{*} \mathrm{KOAE}$ & iron rod & -5470945.340 & -2513761.059 & 2100840.712 \\
\hline KULANI & iron rod & -5464987.184 & -2513732.054 & 2118309.681 \\
\hline MAUNA KEA SUMMIT & SUMMIT 1955 & -5464366.269 & -2493933.083 & 2150467.594 \\
\hline
\end{tabular}


Table 7. WGS-84 Cartesian coordinates-Continued.

\begin{tabular}{|c|c|c|c|c|}
\hline Station Name & Benchmark & $x$ & $Y$ & $\mathrm{Z}$ \\
\hline \multicolumn{5}{|c|}{ August 1989_Continued } \\
\hline $\begin{array}{l}\text { *MAUNA LOA STRIP } \\
\text { MILOLII } \\
\text { MLI }{ }^{7} \\
\text { *MLO } \\
\text { MOANA HAUAE } \\
\text { MOUNTAIN VIEW } \\
\text { *NALI } \\
\text { OUO } \\
\text { PALI } \\
\text { POLIAHU }{ }^{8} \\
\text { SANDHLL } \\
\text { *ULAULA } \\
\text { UWEKAHUNA } \\
\text { WUNG RANCH }\end{array}$ & $\begin{array}{l}\text { HVO } 87-108 \\
\text { NO } 31973 \\
\text { ML1 } \\
\text { STAIR 1955 } \\
\text { MOANA HAUAE } \\
\text { HVO 87-101 } \\
\text { NALI } \\
\text { 76-16 } \\
\text { HVO111 } \\
\text { HVO 88-14 } \\
\text { HVO119 } \\
\text { (none) } \\
\text { HVO113 } \\
\text { HVO } 87-106\end{array}$ & $\begin{array}{l}-5470031.266 \\
-5501158.841 \\
-5482189.849 \\
-5477995.864 \\
-5453130.035 \\
-5454498.510 \\
-5476894.565 \\
-5483781.114 \\
-5468120.382 \\
-5464796.225 \\
-5468453.271 \\
-5480137.507 \\
-5467410.090 \\
-5460266.904\end{array}$ & $\begin{array}{l}-2506030.612 \\
-2459964.734 \\
-2487576.633 \\
-2487729.829 \\
-2548539.796 \\
-2531143.587 \\
-2511431.968 \\
-2476836.302 \\
-2520350.139 \\
-2492640.410 \\
-2516197.535 \\
-2505453.017 \\
-2516254.227 \\
-2526844.876\end{array}$ & $\begin{array}{l}2115500.001 \\
2082660.358 \\
2111928.084 \\
2120552.036 \\
2102293.102 \\
2120875.187 \\
2085450.341 \\
2116261.342 \\
2100336.671 \\
2150664.397 \\
2104808.141 \\
2084773.267 \\
2107790.279 \\
2112234.303\end{array}$ \\
\hline \multicolumn{5}{|c|}{ August 1990} \\
\hline $\begin{array}{l}\text { LYMAN2 } \\
1899 \text { CONE } \\
66 Y Y \\
\text { AHUA } \\
\text { APUA POINT } \\
\text { CAPTAIN COOK } \\
\text { ELEELE } \\
\text { FERN FOREST } \\
\text { HAWAIIAN ACRES } \\
\text { HAWAIIAN BEACHES } \\
\text { HEIHEIAHULU } \\
\text { HILINA PALI } \\
\text { HP6 } \\
\text { HULUHULU } \\
\text { HVO7 }\end{array}$ & $\begin{array}{l}\text { LYMAN NO. } 2 \\
1899 \\
66 Y Y \text { RESET } \\
\text { HVO } 114 \\
\text { APUA POINT } \\
\text { HVO 88-12 } \\
\text { PUU ELEELE } 1976 \\
\text { HVO 89-1 } \\
\text { HVO 87-102 } \\
\text { HVO 87-103 } \\
\text { unmarked pipe } \\
\text { HILINA RESET } 1975 \\
\text { HP-6 EL 124.42 } \\
\text { HULUHULU } \\
\text { HVO7 }\end{array}$ & $\begin{array}{l}-5445971.060 \\
-5473028.901 \\
-5451325.099 \\
-5467762.082 \\
-5467568.274 \\
-5491390.749 \\
-5478438.231 \\
-5458401.501 \\
-5451577.159 \\
-5446938.735 \\
-5453581.870 \\
-5472049.341 \\
-5468952.522 \\
-5465315.402 \\
-5443443.291\end{array}$ & $\begin{array}{l}-2533159.910 \\
-2495131.848 \\
-2548417.226 \\
-2518810.858 \\
-2527222.933 \\
-2455768.481 \\
-2494590.287 \\
-2531794.227 \\
-2539136.504 \\
-2548835.790 \\
-2544183.873 \\
-2516015.326 \\
-2455489.177 \\
-2524702.752 \\
-2557471.211\end{array}$ & $\begin{array}{l}2138839.199 \\
2123112.458 \\
2107738.975 \\
2103350.659 \\
2090533.506 \\
2114392.971 \\
2110845.607 \\
2111447.505 \\
2118338.180 \\
2118100.164 \\
2107868.643 \\
2094380.269 \\
2170430.841 \\
2102542.450 \\
2116435.619\end{array}$ \\
\hline
\end{tabular}

August 1990

\begin{tabular}{|c|c|c|c|c|}
\hline KAENA POINT & KAENA PT & -5463732.427 & -2533690.370 & 2092766.722 \\
\hline KAILUA & HVO $88-11$ & -5489953.952 & -2443731.463 & 2130483.521 \\
\hline KALALUA & iron rod & -5457770.357 & -2537400.255 & 2105661.487 \\
\hline KALOLI-2 & KALOLI 2 & -5444567.092 & -2545063.022 & 2128318.663 \\
\hline KAMOAMOA & HVO158 & -5459919.910 & -2538708.316 & 2096614.692 \\
\hline KEAAU & KEAAU 1949 & -5449690.867 & -2535471.949 & 2127198.322 \\
\hline KEEI & KEEI NO BASE 1948 & -5492297.105 & -2454606.052 & 2112006.018 \\
\hline KULANI & iron rod & -5464987.154 & -2513732.018 & 2118309.662 \\
\hline MAUNA LOA STRIP & HVO $87-108$ & -5470031.229 & -2506030.590 & 2115499.970 \\
\hline MILOLII & NO 31973 & -5501159.002 & -2459964.743 & 2082660.394 \\
\hline $\mathrm{ML1}^{9}$ & ML1 & -5482189.851 & -2487576.616 & 2111928.065 \\
\hline MLO & STAIR 1955 & -5477995.802 & -2487729.798 & 2120552.010 \\
\hline MOANA HAUAE & MOANA HAUAE & -5453129.996 & -2548539.786 & 2102293.050 \\
\hline MOUNTAIN VIEW & HVO $87-101$ & -5454498.581 & -2531143.638 & 2120875.207 \\
\hline OUO & $76-16$ & -5483781.016 & -2476836.353 & 2116261.327 \\
\hline PALI & HVO111 & -5468120.269 & -2520350.184 & 2100336.629 \\
\hline POLIAHU & HVO $88-14$ & -5464796.254 & -2492640.440 & 2150664.422 \\
\hline SANDHILL & HVO119 & -5468453.199 & -2516197.620 & 2104808.089 \\
\hline WUNG RANCH & HVO $87-106$ & -5460266.821 & -2526844.867 & 2112234.270 \\
\hline
\end{tabular}

*Loss of satellite 9, so daily observing sessions shortened to 4.2 hours.

${ }^{1}$ Measured with respect to UWEKAHUNA coordinates in this table.

${ }^{2}$ Measured with respect to KAMOAMOA coordinates in this table.

${ }^{3}$ Measured with respect to KAENA POINT coordinates in this table.

${ }^{4}$ Measured with respect to $66 \mathrm{YY}$ coordinates in this table.

${ }^{5}$ Measured with respect to KEAAU coordinates in this table.

${ }^{6}$ Measured with respect to OUO coordinates in this table.

${ }^{7}$ Relative to the 1988 location of OUO coordinates in this table.

${ }^{8}$ Relative to HP6 coordinates in this table.

${ }^{9}$ Relative to the 1988 location of OUO coordinates in this table. 
Table 8. Latitude, longitude, and height.

\begin{tabular}{|c|c|c|c|c|c|c|c|}
\hline \multirow[t]{2}{*}{ Station Name } & \multicolumn{3}{|c|}{ Latitude } & \multicolumn{3}{|c|}{ Longitude } & \multirow[t]{2}{*}{ Height, M } \\
\hline & \multicolumn{4}{|c|}{ April 1987} & & & \\
\hline LYMAN2 & $19^{\circ}$ & $43^{\prime}$ & $21.90783^{\prime \prime}$ & $-155^{\circ}$ & 3 & $17.26675^{\prime \prime}$ & 26.030 \\
\hline $66 Y Y$ & 19 & 25 & 25.86693 & -154 & 56 & 40.48070 & 254.948 \\
\hline AINAPO TRAIL & 19 & 22 & 24.01569 & -155 & 27 & 28.90794 & 1570.134 \\
\hline APUA POINT & 19 & 15 & 35.48955 & -155 & 11 & 33.52729 & 24.242 \\
\hline BM80-1 & 19 & 19 & 1.14017 & -155 & 10 & 2.70305 & 632.265 \\
\hline GOAT & 19 & 19 & 35.31428 & -155 & 13 & 41.10818 & 829.716 \\
\hline HALONA & 19 & 33 & 19.18200 & -154 & 56 & 28.23862 & 114.842 \\
\hline HAWAIIAN ACRES & 19 & 31 & 30.89500 & -155 & 1 & 32.49825 & 303.809 \\
\hline HAWAIIAN BEACHES & 19 & 31 & 24.68650 & -154 & 55 & 23.76130 & 129.953 \\
\hline HEIHEIAHULU & 19 & 25 & 27.10891 & -154 & 59 & 24.68727 & 537.243 \\
\hline HILINA PALI & 19 & 17 & 40.25410 & -155 & 18 & 26.33012 & 706.368 \\
\hline HP6 & 20 & 1 & 33.92022 & -155 & 49 & 13.92297 & 59.044 \\
\hline HULUHULU & 19 & 22 & 17.38996 & -155 & 12 & 19.52065 & 1069.214 \\
\hline HVO7 & 19 & 30 & 28.21852 & -154 & 50 & 4.70910 & 46.267 \\
\hline KAENA POINT & 19 & 16 & 52.24748 & -155 & 7 & 17.34985 & 40.369 \\
\hline KAIWIKI & 19 & 45 & 21.58620 & -155 & 7 & 54.20832 & 388.607 \\
\hline KALALUA & 19 & 24 & 9.32973 & -155 & 3 & 56.05541 & 683.630 \\
\hline KALOLI-2 & 19 & 37 & 18.60751 & -154 & 56 & 46.53846 & 23.016 \\
\hline KAMAKAIA & 19 & 18 & 3.53623 & -155 & 22 & 16.57665 & 824.707 \\
\hline KAMOAMOA & 19 & 19 & 4.80949 & -155 & 3 & 46.46580 & 43.199 \\
\hline KAPAPALA & 19 & 14 & 16.13163 & -155 & 26 & 49.92369 & 493.848 \\
\hline KEAAU & 19 & 36 & 37.84746 & -155 & 2 & 59.16437 & 202.708 \\
\hline KEAKAPULU FLATS & 19 & 22 & 5.55002 & -155 & 25 & 14.29943 & 1286.773 \\
\hline KOAE & 19 & 21 & 19.41793 & -155 & 19 & 20.69906 & 1009.501 \\
\hline KULANI & 19 & 31 & 13.73647 & -155 & 17 & 56.29830 & 1706.544 \\
\hline MAUNA LOA STRIP & 19 & 29 & 32.74787 & -155 & 23 & 8.42127 & 2060.734 \\
\hline MILOLII & 19 & 11 & 4.37055 & -155 & 54 & 25.69945 & 19.580 \\
\hline MOANA HAUAE & 19 & 22 & 20.59660 & -154 & 57 & 2.87443 & 36.977 \\
\hline MOUNTAIN VIEW & 19 & 32 & 59.47906 & -155 & 6 & 23.34643 & 473.112 \\
\hline NALI & 19 & 12 & 39.38878 & -155 & 21 & 58.17556 & 113.283 \\
\hline PALI & 19 & 21 & 1.92384 & -155 & 15 & 15.18000 & 1020.165 \\
\hline PAPAALOA & 19 & 58 & 4.84899 & -155 & 13 & 42.09289 & 297.567 \\
\hline SANDHILL & 19 & 23 & 34.56079 & -155 & 17 & 29.18271 & 1150.027 \\
\hline UWEKAHUNA & 19 & 25 & $\begin{array}{l}34.50019 \\
15.99833\end{array}$ & $\begin{array}{l}-153 \\
-155\end{array}$ & 17 & 12.47169 & 1269.244 \\
\hline WUNG RANCH & 19 & 27 & 54.42314 & -155 & 10 & 0.26728 & 817.255 \\
\hline
\end{tabular}

August 1988

\begin{tabular}{|c|c|c|c|c|c|c|c|}
\hline LYMAN2 & $19^{\circ}$ & $43^{\prime}$ & $21.90783 "$ & $-155^{\circ}$ & $3^{\prime}$ & $17.26675^{\prime \prime}$ & 26.030 \\
\hline 66YY & 19 & 25 & 25.86689 & -154 & 56 & 40.48052 & 254.887 \\
\hline *APUA POINT & 19 & 15 & 35.48697 & -155 & 11 & 33.52584 & 24.372 \\
\hline BM80-1 & 19 & 19 & 1.13815 & -155 & 10 & 2.70181 & 632.444 \\
\hline *CAPTAIN COOK & 19 & 29 & 12.57364 & -155 & 54 & 20.32293 & 495.816 \\
\hline *HAWAIIAN ACRES & 19 & 31 & 30.89547 & -155 & 1 & 32.49904 & 303.722 \\
\hline *HAWAIIAN BEACHES & 19 & 31 & 24.68600 & -154 & 55 & 23.76171 & 129.939 \\
\hline *HILINA PALI & 19 & 17 & 40.25281 & -155 & 18 & 26.33075 & 706.419 \\
\hline *HP6 & 20 & 1 & 33.92088 & -155 & 49 & 13.92436 & 59.133 \\
\hline *HULUHULU & 19 & 22 & 17.38969 & -155 & 12 & 19.51686 & 1069.323 \\
\hline HVO7 & 19 & 30 & 28.21816 & -154 & 50 & 4.70995 & 46.203 \\
\hline KAENA POINT & 19 & 16 & 52.24456 & -155 & 7 & 17.34995 & 40.494 \\
\hline KAILUA & 19 & 38 & 33.31370 & -156 & 0 & 17.35709 & 26.383 \\
\hline *KALALUA & 19 & 24 & 9.32864 & -155 & 3 & 56.05523 & 683.464 \\
\hline *KALOLI-2 & 19 & 37 & 18.60833 & -154 & 56 & 46.53672 & 22.971 \\
\hline *KAMAKAIA & 19 & 18 & 3.53465 & -155 & 22 & 16.57870 & 824.662 \\
\hline KAMOAMOA & 19 & 19 & 4.80787 & -155 & 3 & 46.46602 & 43.290 \\
\hline *KAPUKAPU & 19 & 16 & 32.51575 & -155 & 15 & 34.47644 & 337.607 \\
\hline KEAAU & 19 & 36 & 37.84701 & -155 & 2 & 59.16423 & 202.776 \\
\hline KEAKAPULU FLATS & 19 & 22 & 5.54907 & -155 & 25 & 14.29885 & 1286.750 \\
\hline KEEI & 19 & 27 & 55.56504 & -155 & 55 & 9.39249 & 32.842 \\
\hline *KOAE & 19 & 21 & 19.41653 & -155 & 19 & 20.69725 & 1009.384 \\
\hline *KULANI & 19 & 31 & 13.73690 & -155 & 17 & 56.29784 & 1706.592 \\
\hline *MAUNA LOA STRIP & 19 & 29 & 32.74741 & -155 & 23 & 8.42185 & 2060.614 \\
\hline *MILOLII & 19 & 11 & 4.37086 & -155 & 54 & 25.70035 & 19.708 \\
\hline *MLl & 19 & 27 & 6.36432 & -155 & 35 & 36.75375 & 4082.388 \\
\hline *MOANA HAUAE & 19 & 22 & 20.59685 & -154 & 57 & 2.87359 & 37.123 \\
\hline MOUNTAIN VIEW & 19 & 32 & 56.47930 & -155 & 6 & 23.34622 & 473.069 \\
\hline *OUO & 19 & 29 & 51.44276 & -155 & 41 & 34.56397 & 2717.557 \\
\hline *PALI & 19 & 21 & 1.92337 & -155 & 15 & 15.18101 & 1020.203 \\
\hline POLIAHU & 19 & 49 & 22.06399 & -155 & 28 & 51.58572 & 4163.806 \\
\hline SANDHILL & 19 & 23 & 34.55921 & -155 & 17 & 29.18083 & 1149.948 \\
\hline UWEKAHUNA & 19 & 25 & 15.99605 & -155 & 17 & 12.47124 & 1269.314 \\
\hline *WUNG RANCH & 19 & 27 & 54.42234 & -155 & 10 & 0.26878 & 817.224 \\
\hline
\end{tabular}


Table 8. Latitude, longitude, and height - Continued.

\begin{tabular}{|c|c|c|c|c|c|c|c|}
\hline \multirow[t]{2}{*}{ Station Name } & \multicolumn{3}{|c|}{ Latitude } & \multicolumn{3}{|c|}{ Longitude } & \multirow[t]{2}{*}{ Height, M } \\
\hline & \multicolumn{4}{|c|}{ August 1989} & & & \\
\hline LYMAN2 & $19^{\circ}$ & $43^{\prime}$ & $21.90783^{\prime \prime}$ & $-155^{\circ}$ & $3^{\prime}$ & $17.26675^{\prime \prime}$ & 26.030 \\
\hline *1899 CONE & 19 & 33 & 45.58037 & -155 & 29 & 31.01566 & 2905.298 \\
\hline 66YY & 19 & 25 & 25.86013 & -154 & 56 & 40.47954 & 254.666 \\
\hline AHUA & 19 & 22 & 44.83449 & -155 & 15 & 57.93868 & 1104.856 \\
\hline APUA POINT & 19 & 15 & 35.48568 & -155 & 11 & 33.52536 & 24.317 \\
\hline BM80-1 & 19 & 19 & 1.13539 & -155 & 10 & 2.69946 & 632.387 \\
\hline CAPTAIN COOK & 19 & 29 & 12.57439 & -155 & 54 & 20.32370 & 495.838 \\
\hline FERN FOREST & 19 & 27 & 29.01491 & -155 & 6 & 55.14843 & 667.009 \\
\hline *HALONA & 19 & 33 & 19.18108 & -154 & 56 & 28.23701 & 114.913 \\
\hline HAWAIIAN ACRES & 19 & 31 & 30.89280 & -155 & 1 & 32.49694 & 303.801 \\
\hline HAWAIIAN BEACHES & 19 & 31 & 24.68393 & -154 & 55 & 23.76096 & 129.984 \\
\hline HEIHEIAHULU & 19 & 25 & 27.09634 & -154 & 59 & 24.68409 & 536.697 \\
\hline HILINA PALI & 19 & 17 & 40.25215 & -155 & 18 & 26.32933 & 706.488 \\
\hline *HP6 & 20 & 1 & 33.92032 & -155 & 49 & 13.92322 & 59.130 \\
\hline HULUHULU & 19 & 22 & 17.38703 & -155 & 12 & 19.51841 & 1069.162 \\
\hline HVO7 & 19 & 30 & 28.21680 & -154 & 50 & 4.70968 & 46.167 \\
\hline KAENA POINT & 19 & 16 & 52.24098 & -155 & 7 & 17.34576 & 40.441 \\
\hline KAILUA & 19 & 38 & 33.31535 & -156 & 0 & 17.35622 & 26.336 \\
\hline KALALUA & 19 & 24 & $9.31995 ;$ & -155 & 3 & 56.04878 & 683.191 \\
\hline KALOLI-2 & 19 & 37 & 18.60701 & -154 & 56 & 46.53835 & 22.982 \\
\hline KAMAKAIA & 19 & 18 & 3.53560 & -155 & 22 & 16.57571 & 824.676 \\
\hline KAMOAMOA & 19 & 19 & 4.80163 & -155 & 3 & 46.46197 & 43.222 \\
\hline KAPUKAPU & 19 & 16 & 32.51604 & -155 & 15 & 34.47131 & 337.789 \\
\hline KEAAU & 19 & 36 & 37.84703 & -155 & 2 & 59.16361 & 202.704 \\
\hline KEAKAPULU FLATS & 19 & 22 & $5.5490 \%$ & -155 & 25 & 14.29865 & 1286.763 \\
\hline KEEI & 19 & 27 & 55.56566 & -155 & 55 & 9.39334 & 32.716 \\
\hline *KOAE & 19 & 21 & 19.41479 & -155 & 19 & 20.69422 & 1009.457 \\
\hline KULANI & 19 & 31 & 13.73601 & -155 & 17 & 56.29937 & 1706.513 \\
\hline MAUNA KEA SUMMIT & 19 & 49 & 14.44472 & -155 & 28 & 5.07329 & 4233.867 \\
\hline *MAUNA LOA STRIP & 19 & 29 & 32.74793 & -155 & 23 & 8.42073 & 2060.761 \\
\hline MILOLII & 19 & 11 & 4.37124 & -155 & 54 & 25.70015 & 19.596 \\
\hline ML1 & 19 & 27 & 6.36441 & -155 & 35 & 36.75371 & 4082.341 \\
\hline *MLO & 19 & 32 & 11.32361 & -155 & 34 & 32.55787 & 3419.922 \\
\hline MOANA HAUAE & 19 & 22 & 20.58948 & -154 & 57 & 2.86756 & 37.074 \\
\hline MOUNTAIN VIEW & 19 & 32 & 56.47853 & -155 & 6 & 23.34528 & 473.049 \\
\hline *NALI & 19 & 12 & 39.38688 & -155 & 21 & 58.17634 & 113.386 \\
\hline OUO & 19 & 29 & 51.44362 & -155 & 41 & 34.56306 & 2717.627 \\
\hline PALI & 19 & 21 & 1.92213 & -155 & 15 & 15.17851 & 1020.108 \\
\hline POLIAHU & 19 & 49 & 22.06400 & -155 & 28 & 51.58774 & 4163.796 \\
\hline SANDHILL & 19 & 23 & 34.55749 & -155 & 17 & 29.17907 & 1149.837 \\
\hline *ULAULA & 19 & 12 & 13.67753 & -155 & 25 & 50.48436 & 324.550 \\
\hline UWEKAHUNA & 19 & 25 & 15.99483 & -155 & 17 & 12.47012 & 1269.273 \\
\hline WUNG RANCH & 19 & 27 & 54.42212 & -155 & 10 & 0.26635 & 817.308 \\
\hline
\end{tabular}

August 1990

\begin{tabular}{lllllrrr}
\hline LYMAN2 & $19^{\circ}$ & $43^{\prime}$ & $21.90783^{\prime \prime}$ & $-155^{\circ}$ & $3^{\prime}$ & $17.26675^{\prime \prime}$ & 26.030 \\
1899 CONE & 19 & 33 & 45.58072 & -155 & 29 & 31.01500 & 2905.228 \\
66YY & 19 & 25 & 25.86015 & -154 & 56 & 40.47914 & 254.550 \\
AHUA & 19 & 22 & 44.83425 & -155 & 15 & 57.93720 & 1104.746 \\
APUA POINT & 19 & 15 & 35.48332 & -155 & 11 & 33.52381 & 24.386 \\
CAPTAIN COOK & 19 & 29 & 12.57422 & -155 & 54 & 20.32358 & 495.807 \\
ELEELE & 19 & 26 & 38.74070 & -155 & 31 & 4.78759 & 3238.165 \\
FERN FOREST & 19 & 27 & 29.01455 & -155 & 6 & 55.14833 & 666.986 \\
HAWAIIAN ACRES & 19 & 31 & 30.89248 & -155 & 1 & 32.49760 & 303.676 \\
HAWAIIAN BEACHES & 19 & 31 & 24.68369 & -154 & 55 & 23.76070 & 129.921 \\
HEIHEIAHULU & 19 & 25 & 27.09528 & -154 & 59 & 24.68368 & 536.752 \\
HILINA PALI & 19 & 17 & 40.25111 & -155 & 18 & 26.32776 & 706.538 \\
HP6 & 20 & 1 & 33.92097 & -155 & 49 & 13.92411 & 59.201 \\
HULUHULU & 19 & 22 & 17.38562 & -155 & 12 & 19.51643 & 1069.015 \\
HVO7 & 19 & 30 & 28.21704 & -154 & 50 & 4.70936 & 46.254 \\
KAENA POINT & 19 & 16 & 52.23860 & -155 & 7 & 17.34453 & 40.492 \\
KAILUA & 19 & 38 & 33.31487 & -156 & 0 & 17.35674 & 26.380 \\
KALALUA & 19 & 24 & 9.31890 & -155 & 3 & 56.04694 & 683.116 \\
KALOLI-2 & 19 & 37 & 18.60710 & $-\| 54$ & 56 & 46.53964 & 23.003 \\
KAMOAMOA & 19 & 19 & 4.79935 & $-\| 55$ & 3 & 46.45774 & 43.287 \\
KEAAU & 19 & 36 & 37.84717 & $-\| 55$ & 2 & 59.16408 & 202.623 \\
KEEI & 19 & 27 & 55.56544 & $-\| 55$ & 55 & 9.39374 & 32.772 \\
KULANI & 19 & 31 & 13.73584 & $-\| 55$ & 17 & 56.30004 & 1706.468 \\
MAUNA LOA STRIP & 19 & 29 & 32.74742 & $-\| 55$ & 23 & 8.42089 & 2060.713 \\
MILOLII & 19 & 11 & 4.37063 & $-\| 55$ & 54 & 25.70209 & 19.752 \\
MLI & 19 & 27 & 6.36386 & $-\| 55$ & 35 & 36.75424 & 4082.331 \\
MLO & 19 & 32 & 11.32353 & $-\| 55$ & 34 & 32.55794 & 3419.850
\end{tabular}


Table 8. Latitude, longitude, and height - Continued.

\begin{tabular}{|c|c|c|c|c|c|c|c|}
\hline Station Name & \multicolumn{3}{|c|}{ Latitude } & \multicolumn{3}{|c|}{ Longitude } & Height, $\mathrm{M}$ \\
\hline \multicolumn{8}{|c|}{ August $1990-$ Continued } \\
\hline $\begin{array}{l}\text { MOANA HAUAE } \\
\text { MOUNTAIN VIEW } \\
\text { OUO } \\
\text { PALI } \\
\text { POLIAHU } \\
\text { SANDHILL } \\
\text { UWEKAHUNA } \\
\text { WUNG RANCH }\end{array}$ & $\begin{array}{l}19^{\circ} \\
19 \\
19 \\
19 \\
19 \\
19 \\
19 \\
19\end{array}$ & $\begin{array}{l}22 \\
32 \\
29 \\
21 \\
49 \\
23 \\
25 \\
27\end{array}$ & $\begin{array}{r}20.58828 \\
56.47818 \\
51.44385 \\
1.92166 \\
22.06443 \\
34.55619 \\
15.99323 \\
54.42194\end{array}$ & $\begin{array}{l}-154^{\circ} \\
-155 \\
-155 \\
-155 \\
-155 \\
-155 \\
-155 \\
-155\end{array}$ & $\begin{array}{l}57 \\
6 \\
41 \\
15 \\
28 \\
17 \\
17 \\
10\end{array}$ & $\begin{array}{r}2.86731 \\
23.34470 \\
34.56007 \\
15.17548 \\
51.58721 \\
29.17539 \\
12.46904 \\
0.26545\end{array}$ & $\begin{array}{r}37.022 \\
473.139 \\
2717.559 \\
1020.016 \\
4163.844 \\
1149.793 \\
1269.218 \\
817.224\end{array}$ \\
\hline
\end{tabular}

* Loss of satellite 9 , so daily observing sessions shortened to 4.4 hours.

above the reference ellipsoid defined in table 2. (At the latitude of Hawaii, 0.01 " of latitude or longitude is about 0.3 m.) Also given in table 7 is the name stamped on the benchmark or the type of mark used, such as an iron rod at KALALUA. All station coordinates in tables 7 and 8 are relative to the position of LYMAN2 computed for the April 1987 survey using NSWC orbits and listed in the bottom half of table 4.

Most station positions were computed from baselines that included LYMAN2 as one endpoint. The exceptions are given in a footnote. For example, for the 1987 survey, the position of HULUHULU was computed from a baseline that had HULUHULU and UWEKAHUNA as endpoints. If in some future re-analysis of these surveys the position of UWEKAHUNA is adjusted, then the position of HULUHULU must be adjusted by the same amount. During the 1989 and 1990 surveys, LYMAN2 was occupied every day.

The loss of satellite 9 during a major portion of the 1988 and 1989 surveys reduced the duration of our daily observing sessions, which resulted in less accurate measurements. Asterisks in tables 7 and 8 identify the stations surveyed when satellite 9 was unavailable.

The position of a few stations, such as KAPUKAPU in 1987, could not be determined because of a large number of cycle slips, mostly in L2-carrier phase measurements. As a result, no coordinates are given for a few stations.

Differences in measured station positions of four pairs of surveys are listed in table 9. The first three survey pairs are for successive annual surveys between 1987 and 1990. The last pair is for the full four years from 1987 to 1990. A positive difference means a measured change to the north, east, or up. At the bottom of table 9, an uncertainty for each component for each survey pair was computed as the square root of the sum of the squares of the uncertainties given in table 5 for the appropriate component and survey. For example, the daily variation in measuring the north/south component was $8 \mathrm{~mm}$ in 1987 and $27 \mathrm{~mm}$ in 1988. (As mentioned in an earlier section, we assume these daily variations are the accuracy of each survey.) The uncertainty in computing the difference in north/south positions between 1987 and 1988 was $\sqrt{27^{2}+8^{2}}=28 \mathrm{~mm}$.

\section{COMPARISON OF GPS AND TRILATERATION MEASUREMENTS}

Trilateration measurements were made in the summit area of Kilauea at about the same time as the GPS surveys. The station-to-station distances measured using a laser instrument and GPS are listed in table 10 and plotted in figure 10. (The 1990 trilateration measurements of MLStrip were not to the GPS benchmark (MAUNA LOA STRIP), but to another benchmark (stamped ML STRIP) located about $200 \mathrm{~m}$ east. Trilateration measurements were also made to ML STRIP in August 1989, and so a change in line length measured to ML STRIP between August 1989 and October 1990 was assumed to be the same as a change in line length to the GPS benchmark.)

Distances computed from our laser measurements are almost always longer than those computed from GPS (figs. 10 and 11 and last column in table 10) because an inadequate refraction correction has been made to the laser measurements. Air temperatures that were measured only at the endpoints, used to compute a refraction correction, are higher than the air temperature averaged along the line-of-sight, and so computed distances are slightly too long. To illustrate this bias, we have plotted in figure 11 the differences between laser and GPS measurements as a function of baseline distance. The dashed line indicates a bias of $5 \mathrm{ppm}$, which means, on average, endpoint temperatures overestimate average line-of-sight temperatures by about $5^{\circ} \mathrm{C}$. (When air temperatures are measured along the entire line between two stations, distances determined by laser and GPS measurements agree to within $0.2 \mathrm{ppm}$ (Prescott and others, 1989).)

In studying active volcanoes, we are concerned with changes in station positions, not absolute positions, and so for our purposes, the bias between laser and GPS measurements is not as great as indicated by figure 11. Furthermore, on active volcanoes we are more apt to measure changes of ten 
Table 9. Coordinate differences between GPS surveys.

[Values expressed in millimeters]

\begin{tabular}{|c|c|c|c|c|c|c|c|c|c|c|c|c|}
\hline \multirow[b]{2}{*}{ Station name } & \multicolumn{3}{|c|}{$1988-1987$} & \multicolumn{3}{|c|}{ 1989-1988 } & \multicolumn{3}{|c|}{$1990-1989$} & \multicolumn{3}{|c|}{$1990-1987$} \\
\hline & $\mathrm{N} / \mathrm{S}$ & $\mathrm{E} / \mathrm{W}$ & U/D & $N / S$ & $\mathrm{E} / \mathrm{W}$ & $\mathrm{U} / \mathrm{D}$ & $\mathrm{N} / \mathrm{S}$ & $E / W$ & U/D & $\mathrm{N} / \mathrm{S}$ & $\mathrm{E} / \mathrm{W}$ & U/D \\
\hline $\begin{array}{l}1899 \text { CONE } \\
66 Y Y \\
\text { AHUA } \\
\text { APUA POINT } \\
\text { BM80-1 }\end{array}$ & $\begin{array}{l}-1 \\
-79 \\
-62\end{array}$ & $\begin{array}{r}6 \\
42 \\
36\end{array}$ & $\begin{array}{l}-61 \\
130 \\
179\end{array}$ & $\begin{array}{r}-208 \\
-40 \\
-85\end{array}$ & $\begin{array}{l}28 \\
14 \\
69\end{array}$ & $\begin{array}{r}-221 \\
55 \\
-57\end{array}$ & $\begin{array}{r}11 \\
2 \\
-6 \\
-70\end{array}$ & $\begin{array}{l}19 \\
12 \\
44 \\
45\end{array}$ & $\begin{array}{r}-70 \\
-116 \\
-20 \\
69\end{array}$ & $\begin{array}{l}-207 \\
-189\end{array}$ & $\begin{array}{r}46 \\
101\end{array}$ & $\begin{array}{r}-398 \\
144\end{array}$ \\
\hline $\begin{array}{l}\text { CAPTAIN COOK } \\
\text { FERN FOREST } \\
\text { HAWAIIAN ACRES } \\
\text { HAWAIIAN BEACHES } \\
\text { HEIHEIAHULU }\end{array}$ & $\begin{array}{r}14 \\
-15\end{array}$ & $\begin{array}{l}-23 \\
-12\end{array}$ & $\begin{array}{l}-87 \\
-13\end{array}$ & $\begin{array}{l}22 \\
-82 \\
-64\end{array}$ & $\begin{array}{r}-31 \\
61 \\
22\end{array}$ & $\begin{array}{l}22 \\
79 \\
45\end{array}$ & $\begin{array}{r}-4 \\
-9 \\
-9 \\
-6 \\
-31\end{array}$ & $\begin{array}{r}11 \\
3 \\
-20 \\
7 \\
12\end{array}$ & $\begin{array}{r}-9 \\
-23 \\
-125 \\
-63 \\
55\end{array}$ & $\begin{array}{r}-77 \\
-85 \\
-418\end{array}$ & $\begin{array}{r}18 \\
17 \\
104\end{array}$ & $\begin{array}{r}-133 \\
-31 \\
-491\end{array}$ \\
\hline $\begin{array}{l}\text { HILINA PALI } \\
\text { HP6 } \\
\text { HULUHULU } \\
\text { HVO7 } \\
\text { KAENA POINT }\end{array}$ & $\begin{array}{r}-40 \\
20 \\
-8 \\
-11 \\
-89\end{array}$ & $\begin{array}{r}-22 \\
-40 \\
111 \\
-24 \\
-3\end{array}$ & $\begin{array}{r}51 \\
89 \\
109 \\
-64 \\
125\end{array}$ & $\begin{array}{r}-20 \\
-17 \\
-82 \\
-42 \\
-110\end{array}$ & $\begin{array}{r}41 \\
32 \\
-45 \\
7 \\
122\end{array}$ & $\begin{array}{r}69 \\
-37 \\
-161 \\
-36 \\
-53\end{array}$ & $\begin{array}{r}-30 \\
18 \\
-41 \\
-9 \\
-71\end{array}$ & $\begin{array}{r}46 \\
-25 \\
57 \\
10 \\
35\end{array}$ & $\begin{array}{r}50 \\
72 \\
-147 \\
87 \\
51\end{array}$ & $\begin{array}{r}-90 \\
21 \\
-131 \\
-44 \\
-270\end{array}$ & $\begin{array}{r}69 \\
-33 \\
123 \\
-7 \\
154\end{array}$ & $\begin{array}{r}170 \\
157 \\
-199 \\
-13 \\
129\end{array}$ \\
\hline $\begin{array}{l}\text { KAILUA } \\
\text { KALALUA } \\
\text { KALOLI-2 } \\
\text { KAMAKAIA } \\
\text { KAMOAMOA }\end{array}$ & $\begin{array}{r}-33 \\
25 \\
-49 \\
-51\end{array}$ & $\begin{array}{r}5 \\
50 \\
-60 \\
-6\end{array}$ & $\begin{array}{r}-166 \\
-45 \\
-45 \\
91\end{array}$ & $\begin{array}{r}51 \\
-268 \\
-41 \\
28 \\
-191\end{array}$ & $\begin{array}{r}25 \\
188 \\
-47 \\
87 \\
118\end{array}$ & $\begin{array}{r}-47 \\
-273 \\
11 \\
14 \\
-68\end{array}$ & $\begin{array}{r}-15 \\
-30 \\
4 \\
-69\end{array}$ & $\begin{array}{r}-15 \\
53 \\
-37 \\
123\end{array}$ & $\begin{array}{r}44 \\
-75 \\
21 \\
65\end{array}$ & $\begin{array}{r}-331 \\
-12 \\
-311\end{array}$ & $\begin{array}{l}246 \\
-34 \\
235\end{array}$ & $\begin{array}{r}-514 \\
-13 \\
88\end{array}$ \\
\hline $\begin{array}{l}\text { KAPUKAPU } \\
\text { KEAAU } \\
\text { KEAKAPULU FLATS } \\
\text { KEEI } \\
\text { KOAE }\end{array}$ & $\begin{array}{l}-13 \\
-29 \\
-43\end{array}$ & $\begin{array}{r}4 \\
17 \\
53\end{array}$ & $\begin{array}{r}68 \\
-23 \\
-117\end{array}$ & $\begin{array}{r}9 \\
0 \\
0 \\
24 \\
-53\end{array}$ & $\begin{array}{r}150 \\
18 \\
5 \\
-13 \\
88\end{array}$ & $\begin{array}{r}182 \\
-72 \\
13 \\
-37 \\
73\end{array}$ & $\begin{array}{r}5 \\
-6\end{array}$ & $\begin{array}{l}-14 \\
-11\end{array}$ & $\begin{array}{l}-81 \\
56\end{array}$ & -8 & 8 & -85 \\
\hline $\begin{array}{l}\text { KULANI } \\
\text { MAUNA LOA STRIP } \\
\text { MILOLII } \\
\text { ML1 } \\
\text { MLO }\end{array}$ & $\begin{array}{r}14 \\
14 \\
9\end{array}$ & $\begin{array}{r}13 \\
-17 \\
-26\end{array}$ & $\begin{array}{r}48 \\
-120 \\
128\end{array}$ & $\begin{array}{r}-28 \\
-16 \\
12 \\
3\end{array}$ & $\begin{array}{r}-44 \\
32 \\
6 \\
1\end{array}$ & $\begin{array}{r}-79 \\
147 \\
-112 \\
-46\end{array}$ & $\begin{array}{r}-4 \\
15 \\
-17 \\
-17 \\
-1\end{array}$ & $\begin{array}{r}-20 \\
-4 \\
-57 \\
-15 \\
-2\end{array}$ & $\begin{array}{r}-45 \\
-48 \\
196 \\
-9 \\
-72\end{array}$ & $\begin{array}{r}-18 \\
13 \\
4\end{array}$ & $\begin{array}{r}-51 \\
11 \\
-77\end{array}$ & $\begin{array}{l}-76 \\
-21 \\
172\end{array}$ \\
\hline $\begin{array}{l}\text { MOANA HAUAE } \\
\text { MOUNTAIN VIEW } \\
\text { OUO } \\
\text { PALI } \\
\text { POLIAHU }\end{array}$ & $\begin{array}{r}8 \\
8 \\
-15\end{array}$ & $\begin{array}{r}24 \\
5 \\
-30\end{array}$ & $\begin{array}{r}145 \\
-43 \\
38\end{array}$ & $\begin{array}{r}-227 \\
-24 \\
26 \\
-38 \\
1\end{array}$ & $\begin{array}{r}176 \\
28 \\
27 \\
73 \\
-58\end{array}$ & $\begin{array}{r}-49 \\
-20 \\
70 \\
-95 \\
-11\end{array}$ & $\begin{array}{r}-35 \\
-10 \\
9 \\
-12 \\
11\end{array}$ & $\begin{array}{r}7 \\
16 \\
87 \\
88 \\
15\end{array}$ & $\begin{array}{r}-52 \\
90 \\
-68 \\
-92 \\
49\end{array}$ & $\begin{array}{r}-254 \\
-26 \\
-65\end{array}$ & $\begin{array}{r}207 \\
49 \\
131\end{array}$ & $\begin{array}{r}44 \\
27 \\
-149\end{array}$ \\
\hline $\begin{array}{l}\text { SANDHILL } \\
\text { UWEKAHUNA } \\
\text { WUNG RANCH }\end{array}$ & $\begin{array}{l}-48 \\
-70 \\
-24\end{array}$ & $\begin{array}{r}55 \\
14 \\
-44\end{array}$ & $\begin{array}{r}-79 \\
69 \\
-31\end{array}$ & $\begin{array}{r}-53 \\
-38 \\
-7\end{array}$ & $\begin{array}{l}51 \\
32 \\
71\end{array}$ & $\begin{array}{r}-111 \\
-40 \\
84\end{array}$ & $\begin{array}{r}-39 \\
-47 \\
-5\end{array}$ & $\begin{array}{r}107 \\
32 \\
26\end{array}$ & $\begin{array}{l}-44 \\
-56 \\
-84\end{array}$ & $\begin{array}{r}-140 \\
-155 \\
-36\end{array}$ & $\begin{array}{r}213 \\
78 \\
53\end{array}$ & $\begin{array}{r}-234 \\
-27 \\
-31\end{array}$ \\
\hline${ }^{1}$ Uncertainties & (28) & (44) & (82) & (34) & $(47)$ & $(96)$ & (22) & (32) & (89) & (12) & $(28)$ & (74) \\
\hline
\end{tabular}

'Uncertainties are the square root of the sum of the squares of the uncertainties given for the appropriate component for each survey in table 5. For example, for the 1988 and 1987 surveys, the uncertainty of the difference of the N/S component was $\left[\sqrt{27^{2}+8^{2}}=28\right]$.

parts per million or more, in which case laser and GPS measurements record similar changes in line lengths (fig. 12).

\section{STABLE BASELINES}

Annual measurements across three baselines, which did not span areas of seismic or volcanic activity, are shown in figure $13 A$. The range of north/south or east/west positions is usually within $30 \mathrm{~mm}$, with the 1988 measurement showing the largest variation. The range of vertical positions is
$70 \mathrm{~mm}$ or more. There appears to be a trend of increasing elevation difference between LYMAN2 and HP6, which may represent a mistake in measuring antenna height in 1987 or 1990 or illustrate the limitation of the single-parameter tropospheric model and the lack of water vapor measurements. (LYMAN2 is on the windward side of the island where annual rainfall is 180 inches (5 m); HP6 is on the arid leeward side where annual rainfall is less than $0.1 \mathrm{~m}$.) Although there is a 4,000-m-elevation difference between LYMAN2 and POLIAHU, this baseline has the same repeatability as the other two stable baselines. 
Table 10. Comparison of trilateration and GPS measurements.

\begin{tabular}{|c|c|c|c|c|c|}
\hline \multirow[t]{2}{*}{ Stations } & \multicolumn{2}{|c|}{ Trilateration } & \multicolumn{2}{|c|}{ GPS Survey } & \multirow{2}{*}{$\begin{array}{c}\text { Difference } \\
\text { m }\end{array}$} \\
\hline & Date & Length, m & Date & Length, m & \\
\hline Uwekahuna - Sandhill & $\begin{array}{r}\text { Nov. 5, } 1986 \\
\text { Aug. 4, } 1988 \\
\text { Aug. } 18,1989 \\
\text { Oct. 2, } 1990\end{array}$ & $\begin{array}{l}3159.911 \\
3159.883 \\
3159.850 \\
3159.856\end{array}$ & $\begin{array}{l}\text { Apr } 1987 \\
\text { Aug } 1988 \\
\text { Aug } 1989 \\
\text { Aug } 1990\end{array}$ & $\begin{array}{l}3159.847 \\
3159.826 \\
3159.840 \\
3159.845\end{array}$ & $\begin{array}{l}0.064 \\
0.057 \\
0.010 \\
0.011\end{array}$ \\
\hline Uwekahuna - Pali & $\begin{array}{r}\text { Nov. 5, } 1986 \\
\text { Aug. 4, } 1988 \\
\text { Aug. } 18,1989 \\
\text { Oct. } 2,1990\end{array}$ & $\begin{array}{l}8534.568 \\
8534.524 \\
8534.491 \\
8534.489\end{array}$ & $\begin{array}{l}\text { Apr } 1987 \\
\text { Aug } 1988 \\
\text { Aug } 1989 \\
\text { Aug } 1990\end{array}$ & $\begin{array}{l}8534.525 \\
8534.460 \\
8534.476 \\
8534.467\end{array}$ & $\begin{array}{l}0.043 \\
0.064 \\
0.015 \\
0.022\end{array}$ \\
\hline Uwekahuna - Kulani & $\begin{array}{r}\text { Nov. } 4,1986 \\
\text { Aug. } 4,1988 \\
\text { Aug. } 18,1989 \\
\text { Oct. } 2,1990\end{array}$ & $\begin{array}{l}11085.428 \\
11085.582 \\
11085.601 \\
11085.645\end{array}$ & $\begin{array}{l}\text { Apr } 1987 \\
\text { Aug } 1988 \\
\text { Aug } 1989 \\
\text { Aug } 1990\end{array}$ & $\begin{array}{l}11085.461 \\
11085.541 \\
11085.560 \\
11085.610\end{array}$ & $\begin{array}{c}-0.033 \\
0.041 \\
0.041 \\
0.035\end{array}$ \\
\hline Uwekahuna - MLStrip & $\begin{array}{r}\text { Jul. 2, } 1987 \\
\text { Aug. 4, } 1988 \\
\text { Aug. 18, } 1989 \\
\text { Oct. 18, } 1990\end{array}$ & $\begin{array}{l}13070.316 \\
13070.380 \\
13070.378 \\
13070.430^{*}\end{array}$ & $\begin{array}{l}\text { Apr } 1987 \\
\text { Aug } 1988 \\
\text { Aug } 1989 \\
\text { Aug } 1990\end{array}$ & $\begin{array}{l}13070.208 \\
13070.252 \\
13070.298 \\
13070.347\end{array}$ & $\begin{array}{l}0.108 \\
0.128 \\
0.080 \\
0.083\end{array}$ \\
\hline Sandhill - Pali & $\begin{array}{r}\text { Nov. 5, } 1986 \\
\text { Aug. 4, } 1988 \\
\text { Aug. 18, } 1989 \\
\text { Oct. 19, } 1990\end{array}$ & $\begin{array}{l}6111.516 \\
6111.460 \\
6111.370 \\
6111.335\end{array}$ & $\begin{array}{l}\text { Apr } 1987 \\
\text { Aug } 1988 \\
\text { Aug } 1989 \\
\text { Aug } 1990\end{array}$ & $\begin{array}{l}6111.462 \\
6111.378 \\
6111.381 \\
6111.349\end{array}$ & $\begin{array}{r}0.054 \\
0.082 \\
-0.011 \\
-0.014\end{array}$ \\
\hline Sandhill - Kulani & $\begin{array}{r}\text { Nov. 4,1986 } \\
\text { Aug. } 4,1988 \\
\text { Aug. } 18,1989 \\
\text { Oct. } 2,1990\end{array}$ & $\begin{array}{l}14155.598 \\
14155.735 \\
14155.743 \\
14155.744\end{array}$ & $\begin{array}{l}\text { Apr } 1987 \\
\text { Aug } 1988 \\
\text { Aug } 1989 \\
\text { Aug } 1990\end{array}$ & $\begin{array}{l}14155.603 \\
14155.671 \\
14155.703 \\
14155.746\end{array}$ & $\begin{array}{r}-0.005 \\
0.064 \\
0.040 \\
-0.002\end{array}$ \\
\hline Sandhill - MLStrip & $\begin{array}{r}\text { Jul. 2, } 1987 \\
\text { Aug. 4, } 1988 \\
\text { Aug. 18, } 1989 \\
\text { Oct. 18, } 1990\end{array}$ & $\begin{array}{l}14838.157 \\
14838.238 \\
14838.284 \\
14838.338^{*}\end{array}$ & $\begin{array}{l}\text { Apr } 1987 \\
\text { Aug } 1988 \\
\text { Aug } 1989 \\
\text { Aug } 1990\end{array}$ & $\begin{array}{l}14838.052 \\
14838.123 \\
14838.203 \\
14838.295\end{array}$ & $\begin{array}{l}0.105 \\
0.115 \\
0.081 \\
0.043\end{array}$ \\
\hline Pali - MLStrip & $\begin{array}{r}\text { Jul. 2, } 1987 \\
\text { Aug. 4, } 1988 \\
\text { Aug. 18, } 1989 \\
\text { Oct. 18, } 1990\end{array}$ & $\begin{array}{l}20943.477 \\
20943.527 \\
20943.511 \\
20943.546^{*}\end{array}$ & $\begin{array}{l}\text { Apr } 1987 \\
\text { Aug } 1988 \\
\text { Aug } 1989 \\
\text { Aug } 1990\end{array}$ & $\begin{array}{l}20943.358 \\
20943.342 \\
20943.422 \\
20943.482\end{array}$ & $\begin{array}{l}0.119 \\
0.185 \\
0.089 \\
0.064\end{array}$ \\
\hline
\end{tabular}

${ }^{*}$ Change relative to trilateration benchmark.

Annual measurements of three shorter baselines are shown in figure 13B. MAUNA LOA STRIP and KEAKAPULU FLATS both lie in the Hilea-Kaoiki seismic area, where several earthquakes greater than 5.0 magnitude occurred between 1981 and 1983. During the four years spanned by our surveys, however, earthquake activity was low, and so for that time period we consider these baselines stable. The range of north/south or east/west positions was within $30 \mathrm{~mm}$; however, the range of vertical positions was more than $100 \mathrm{~mm}$ for the baselines that included KULANI and MAUNA LOA STRIP. (If the 1988 survey is excluded, the range of vertical positions for these two baselines was less than $60 \mathrm{~mm}$. Both baselines were measured during the shortened observing sessions in 1988; a six-hour observing session was used to measure the baseline to KEAKAPULU FLATS.) In view of these measurements, as well as the earlier discussion about daily variations in repeating baseline measurements, on average, single-day measurements yield north/south and east/west positions to within $30 \mathrm{~mm}$ and vertical positions to $60 \mathrm{~mm}$. Those baselines measured during shortened observing sessions in 1988 are less accurate by as much as a factor of two.

\section{HEIGHT OF THE GEOID}

Though vertical positions are the most difficult to measure with GPS, an accuracy of $100 \mathrm{~mm}$ or better is adequate to determine height of the geoid if elevations from leveling surveys are also available. GPS measures geometric heights, the height that would be measured if a long graduated bar extended from Earth's center of mass to the surface. Elevations determined from leveling surveys are orthometric heights, which are influenced by the gravity field. Height of the geoid is the difference between these two elevations, here defined as geometric minus orthometric elevation. 


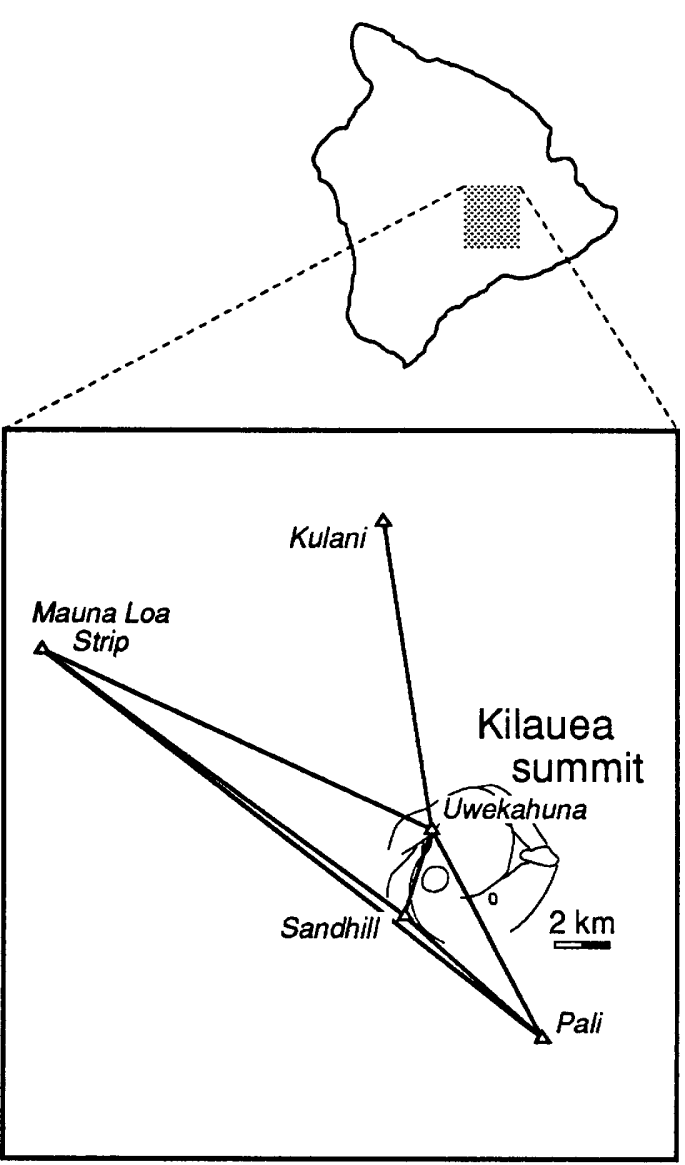

- laser measurements

- GPS measurements
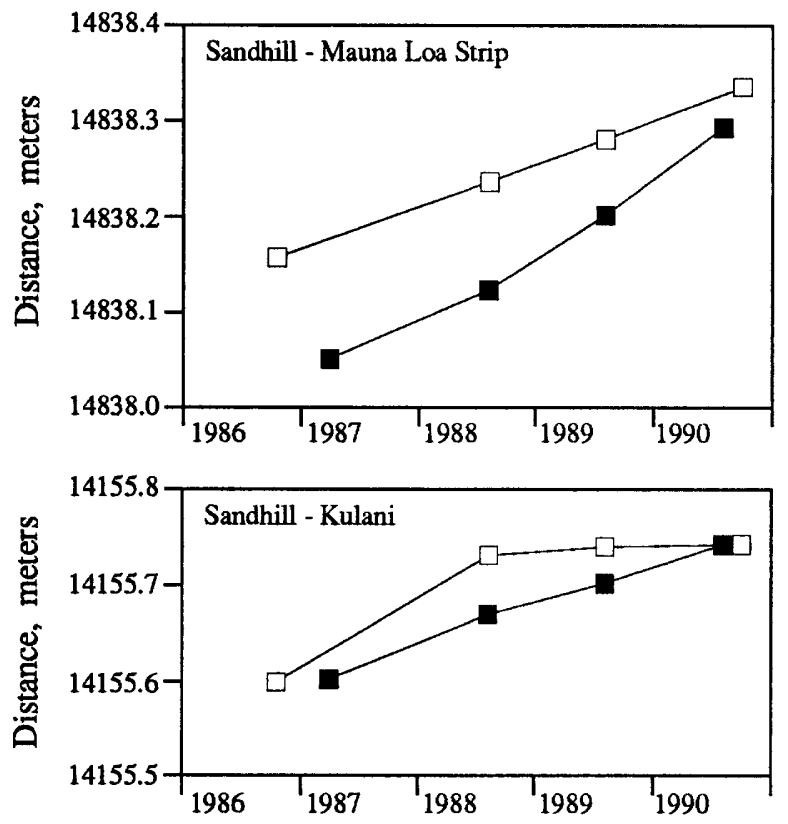
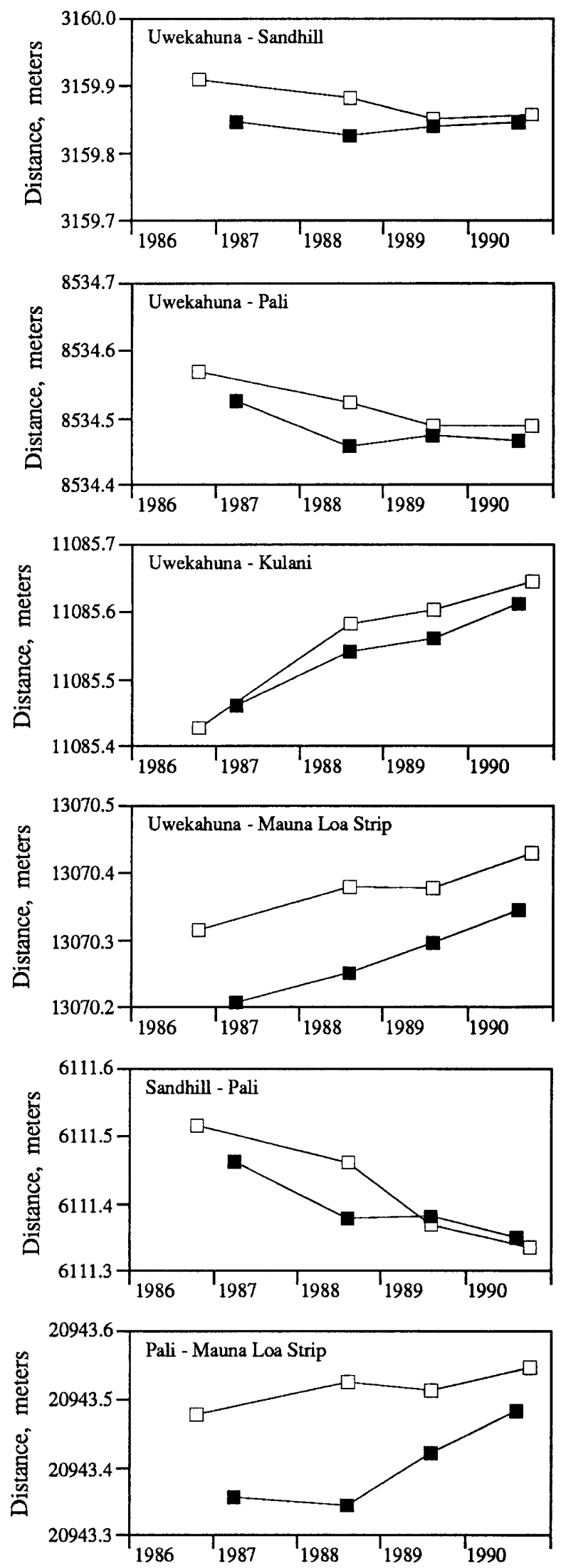

Figure 10. Comparison of baseline distances determined by laser and GPS measurements. Location of each baseline is shown in the upper lefthand corner. 


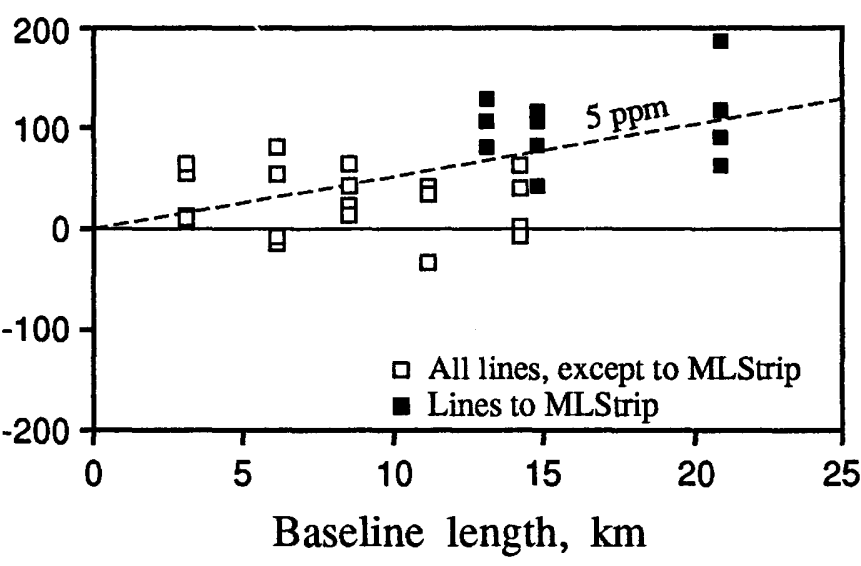

Figure 11. Difference between laser and GPS measurements, plotted as a function of baseline length. A difference of 5 parts per million is shown as a dashed line.

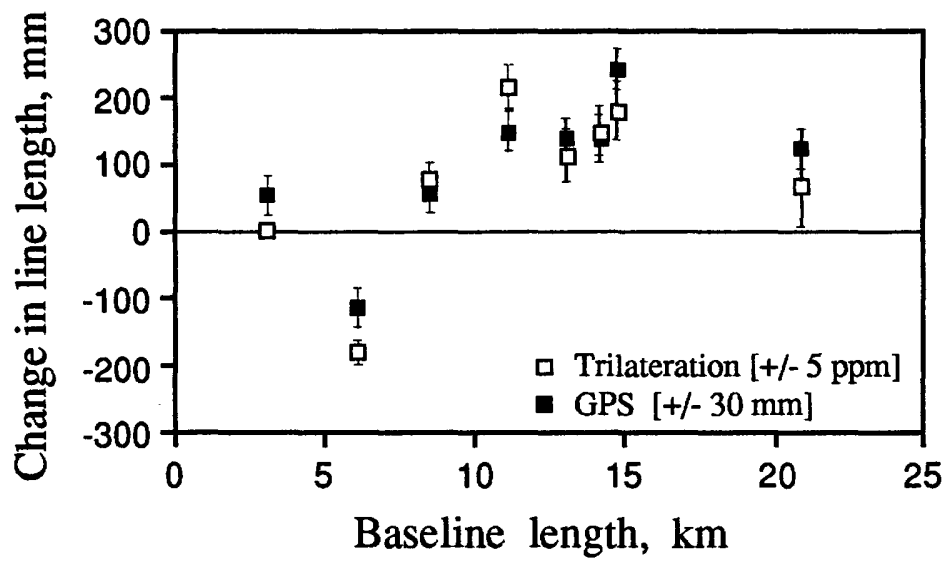

Figure 12. Measured changes in line lengths, determined from laser and GPS measurements, between April 1987 and August 1990.

We illustrate geoid height by considering different determinations of the elevation of the summit of Mauna $\mathrm{Kea}$, the highest peak in the Pacific basin. Leveling and triangulation surveys were used to determine the summit of Mauna Kea to be 4,205 meters above sea level (Mauna Kea quadrangle 7.5-minute topographic series, U.S. Geological Survey, 1982). A GPS measurement made on August 25,1989 was used to compute an elevation difference of 4,207.8 $\mathrm{m}$ between LYMAN2 and the benchmark at the true summit of Mauna Kea (stamped SUMMIT 1955). From a 1957 survey, LYMAN2 was $8.2 \mathrm{~m}$ above mean high sea level, established at a nearby tide gage in Hilo Bay. If we include a $0.2 \mathrm{~m}$ rise of sea level in Hilo Bay since 1957 (Moore, 1987), the present geometric height of the summit of Mauna Kea is 4,215.8 m above mean sea level in Hilo Bay. The difference between geometric and orthometric elevations means the geoid at the summit of Mauna Kea is raised $11 \mathrm{~m}$, which corresponds to a hori- zontal gradient between Hilo and Mauna Kea of $0.24 \mathrm{~m} /$ $\mathrm{km}$. This is similar to the maximum geoid heights determined elsewhere along the Hawaiian island chain, for example across Molokai where the geoid height rises $12 \mathrm{~m}$ over a distance of about $100 \mathrm{~km}$ (Watts, 1979).

We have determined geoid heights elsewhere on the island of Hawaii using geometric elevations from GPS measurements and orthometric elevations determined either from an extensive leveling survey conducted across Kilauea in February 1989 or orthometric elevations of several GPS benchmarks taken from USGS topographic maps. Relative to LYMAN2, geoid heights are about $11 \mathrm{~m}$ in the summit areas of Mauna Kea and Mauna Loa and $5 \mathrm{~m}$ in the summit area of Kilauea (fig. 14). LYMAN2, KAPUKAPU, and MILOLII are at nearly the same geoid height.

As suggested by Watts (1979), our map of geoid heights across Hawaii probably reflects two major components: (1) the broad high shape of the island above the sea floor and (2) subsidence of the rigid lithosphere into a viscous asthenosphere caused by the weight of the volcanoes.

\section{SLOW SUBSIDENCE OF THE SUMMIT AREA OF KILAUEA VOLCANO}

Leveling surveys have shown a slow subsidence of the summit area of Kilauea since the beginning of an eruption along the east rift zone in January 1983. HVO27, a leveling benchmark located near the UWEKHUNA GPS benchmark, $3 \mathrm{~km}$ north of the center of subsidence, has subsided at an annual rate of $20 \mathrm{~mm} / \mathrm{yr}$ since February 1983 (fig. 15). HVO32, located within $2 \mathrm{~km}$ of the center of subsidence, has subsided four times faster. Our GPS measurements also recorded the subsidence, as well as contraction of the summit area.

The three-dimensional displacement of UWEKAHUNA and SANDHILL, relative to LYMAN2, are shown in figure 16. Between April 1987 and August 1990, UWEKAHUNA moved south-southeast at a rate of $50 \mathrm{~mm} / \mathrm{yr}$, and SANDHILL moved southeast at a faster rate of 80 $\mathrm{mm} / \mathrm{yr}$ (fig. 16). The subsidence rate of $20 \mathrm{~mm} / \mathrm{yr}$ near

Figure 13. Measurements of six stable baselines on the island of Hawaii. We suspect these were stable baselines during the period of our surveys because no significant seismic or volcanic activity occurred beneath these lines between 1987 and 1990. A, Baselines between LYMAN2 and HP6, POLIAHU, and KAILUA. $B$, Baselines between LYMAN2 and KULANI, MAUNA LOA STRIP, and KEAKAPULU FLATS. An error bar is five times the standard error computed using the Bernese software package. Error bars are only shown when they are larger than the symbol. Within the error bars, a horizontal trend, indicated as a dashed line segment, can account for the measured variation of each component, which supports the claim that, within the uncertainty of our measurements, these were stable baselines. 
A

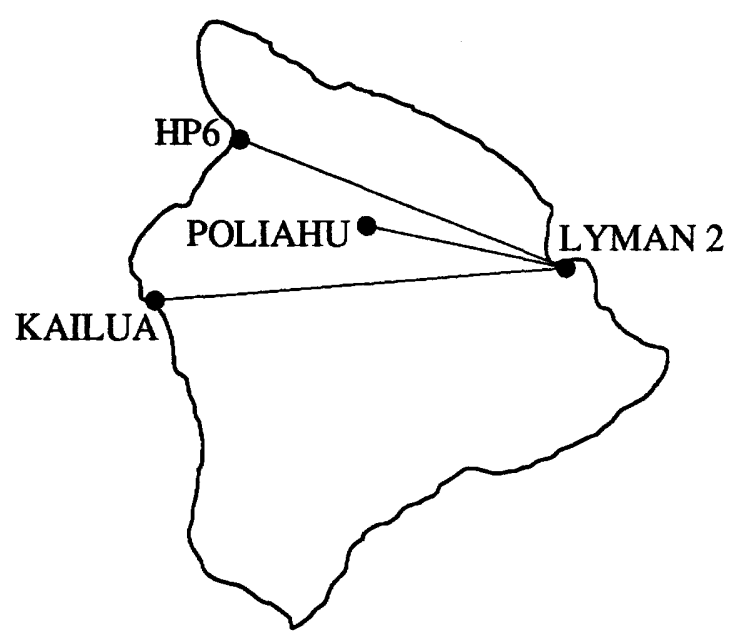

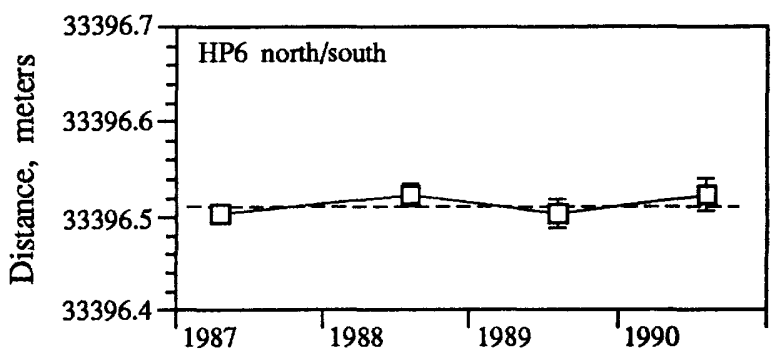
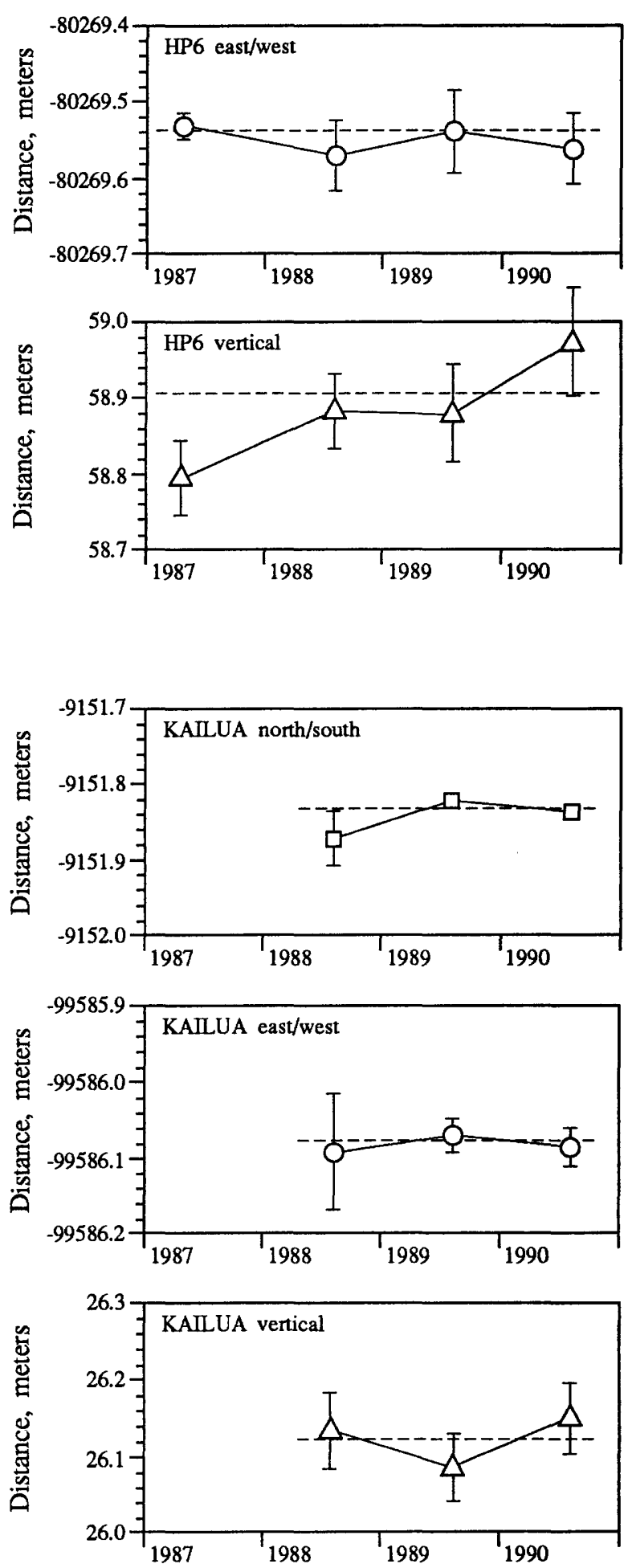
$B$

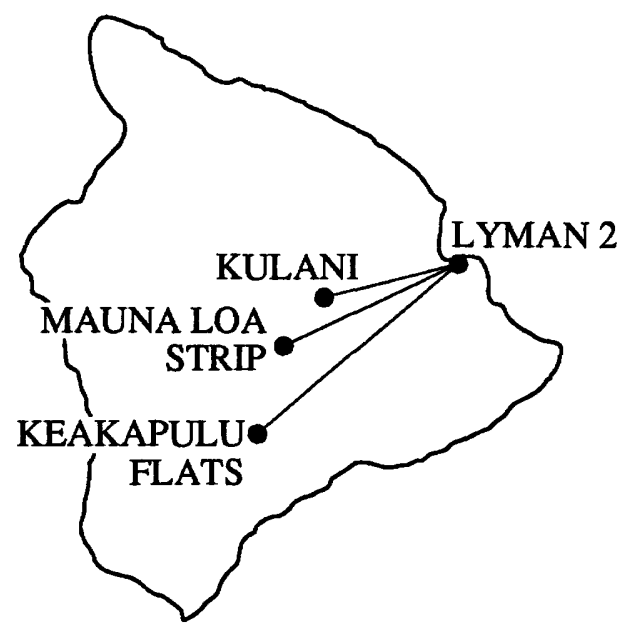

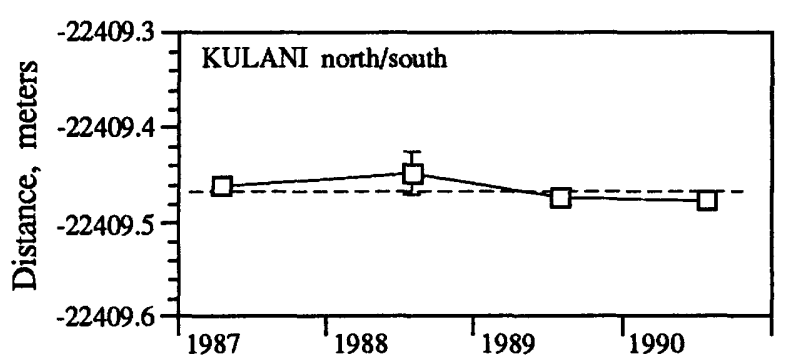
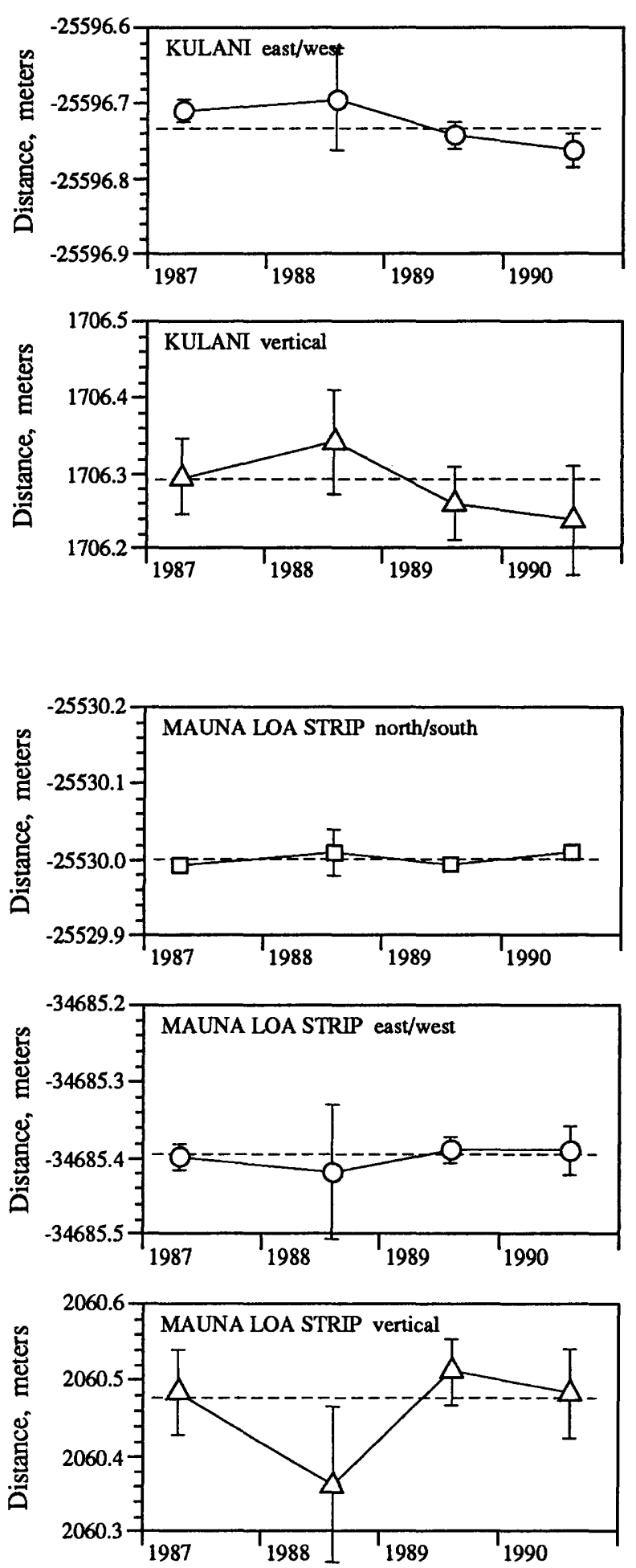

Figure 13.-Continued. 


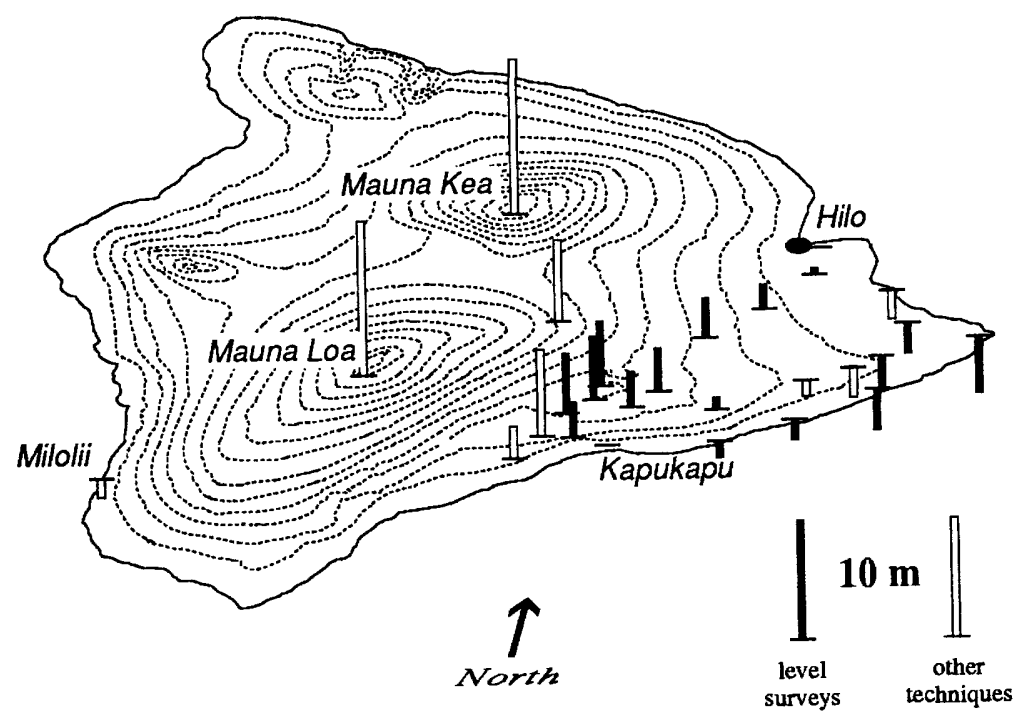

Figure 14. Geoid heights relative to Hilo: difference between geometric and orthometric heights. Geometric heights determined by GPS measurements. Orthometric heights determined either by leveling surveys or elevations of topographic control points on USGS topographic maps.

UWEKAHUNA, indicated by the leveling benchmark HVO27, was not resolved by our GPS; however, our GPS measurements easily resolved the $80 \mathrm{~mm} / \mathrm{yr}$ subsidence of SANDHILL (fig. 15).

Assuming the subsidence pattern can be modeled as the contraction of a pressure source located $4 \mathrm{~km}$ beneath the subsidence center shown in figure 16, which represents a shallow magma reservoir, the subsidence rate at Sandhill corresponds to the removal of $0.01 \mathrm{~km}^{3} / \mathrm{yr}$ of magma. This rate is 10 percent of the average eruptive rate of 0.1 $\mathrm{km}^{3} / \mathrm{yr}$ from 1983 to 1986 , which is corrected for 20 percent vesiculation of the erupted lava (Heliker and Wright, 1991). If the eruptive rate has continued unchanged through 1990 , then only 10 percent of the erupted lava can be accounted for by net removal of magma from the summit reservoir. The other 90 percent must correspond to the rate magma is being supplied to Kilauea from a source deeper than the summit reservoir.

\section{SEAWARD MOVEMENT OF THE SOUTH FLANK OF KILAUEA VOLCANO}

Seaward displacement occurs along the most seismically active portion of the south flank, from APUA POINT to KAMOAMOA (fig. 17). Between the 1987 and 1988 surveys and again between the 1989 and 1990 surveys, the coastline from APUA POINT to KAMOAMOA moved seaward at annual rates of 50 to $100 \mathrm{~mm} / \mathrm{yr}$. During the same time periods, no significant ground displacement was measured east of KAMOAMOA or along the north flank of Kilauea.
Movement along the south flank was first revealed by triangulation and trilateration surveys conducted since 1914 (Swanson and others, 1976). Seaward displacement is driven by intrusion of pressurized magma into a rift zone, which causes immediate compression of the adjacent section of the south flank. Persistent earthquake zones beneath the south flank reveal the most mobile sections of the south flank, though seaward displacement may also occur, at times, elsewhere on Kilauea, for example southwest of the summit area as indicated by persistent southward displacement at KOAE, KAMAKAIA, and HILINA PALI (fig. 17).

During the four years of GPS measurements, the largest ground displacement were associated with a magnitude 6.1 earthquake on June 26, 1989, beneath the south flank. The epicenter was located a few kilometers north of the KAMOAMOA GPS station, between the axis of the east rift zone and the coastline (fig. 18). The focal mechanism is consistent with seaward displacement of the south flank over older ocean crust (Koyanagi and others, 1989). The pattern of horizontal displacement determined using GPS also indicates seaward displacement of as much as $0.3 \mathrm{~m}$ (fig. 18).

The pattern of horizontal displacement can be reproduced by a rectangular fault embedded in a homogeneous, isotropic, elastic half-space with displacement constant across the fault. Analytic expressions for surface displacement were given by Okada (1985). Eight parameters are determined from this model: latitude, longitude, and depth of one corner of the fault; length and width of the fault; dip and strike angle of the fault; and the amount of dipslip displacement across the fault. The values of these 

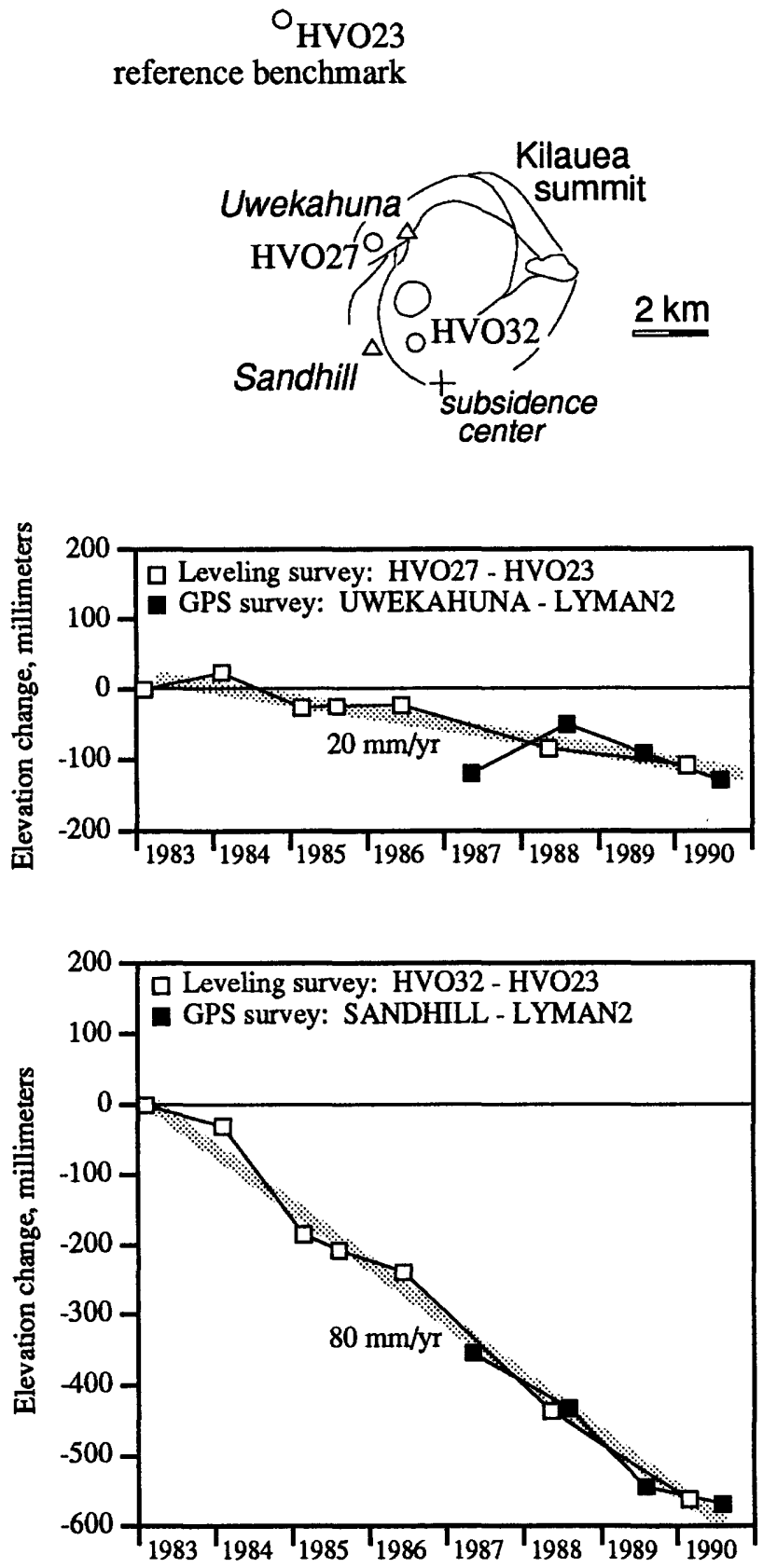

Figure 15. Slow subsidence of summit area of Kilauea, indicated by results of leveling surveys. Locations of leveling benchmarks (circles) and GPS benchmarks (triangles) shown at the top. Upper plot indicates slow subsidence at an average rate of $20 \mathrm{~mm} / \mathrm{yr}$ of the leveling benchmark HVO27, located near the UWEKAHUNA GPS benchmark. Bottom plot also indicates slow subsidence, relative to $\mathrm{HVO} 23$, of the leveling benchmark HVO32 located within $2 \mathrm{~km}$ of subsidence center. Changes in vertical positions of the GPS benchmarks UWEKAHUNA and SANDHILL shown as solid squares in the two plots.

Figure 16. Three-dimensional displacement of two GPS stations in the summit area of Kilauea, UWEKAHUNA and SANDHILL, relative to LYMAN2. Both stations indicate slow subsidence and contraction of summit area, probably the result of slow net withdrawal of magma from summit reservoir.

Horizontal movements - GPS

Earthquake locations

APRIL 1987 TO AUGUST 1988
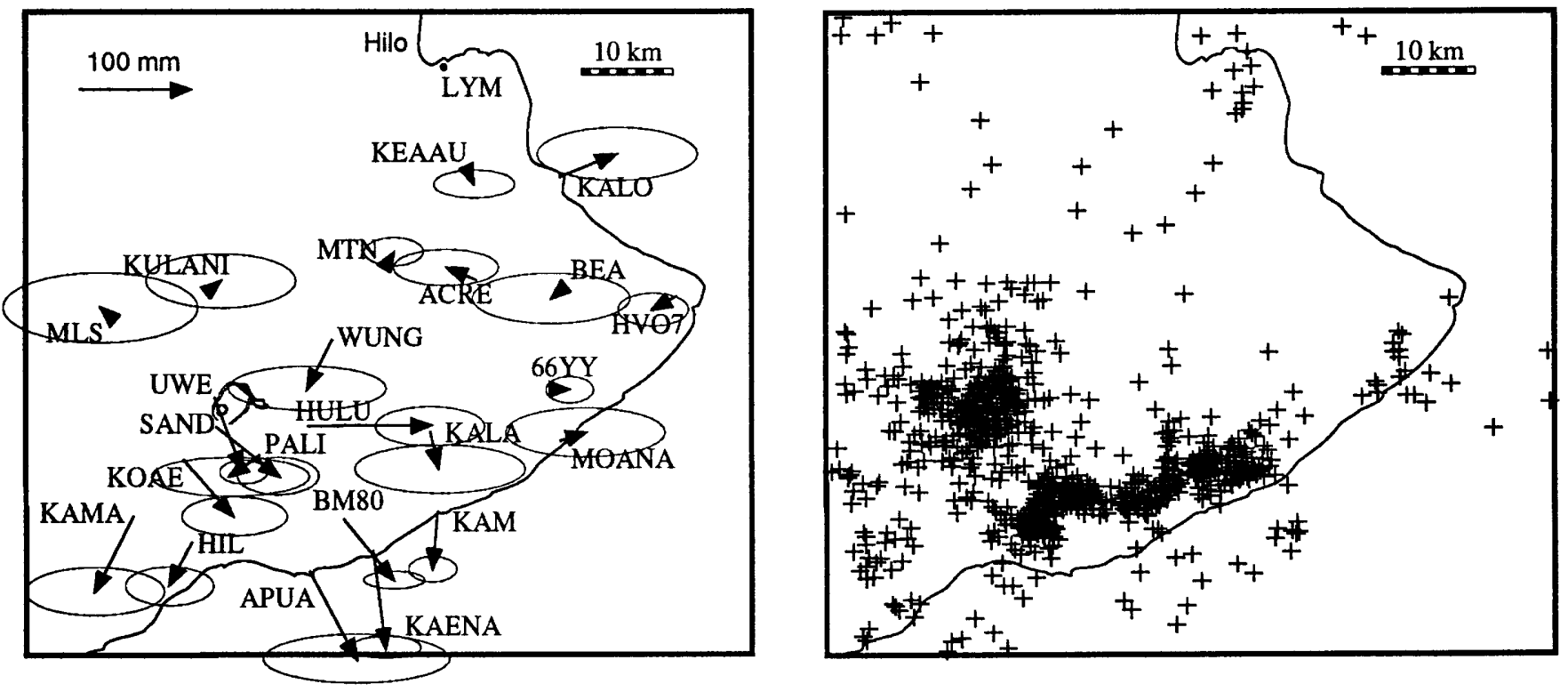

AUGUST 1989 TO AUGUST 1990
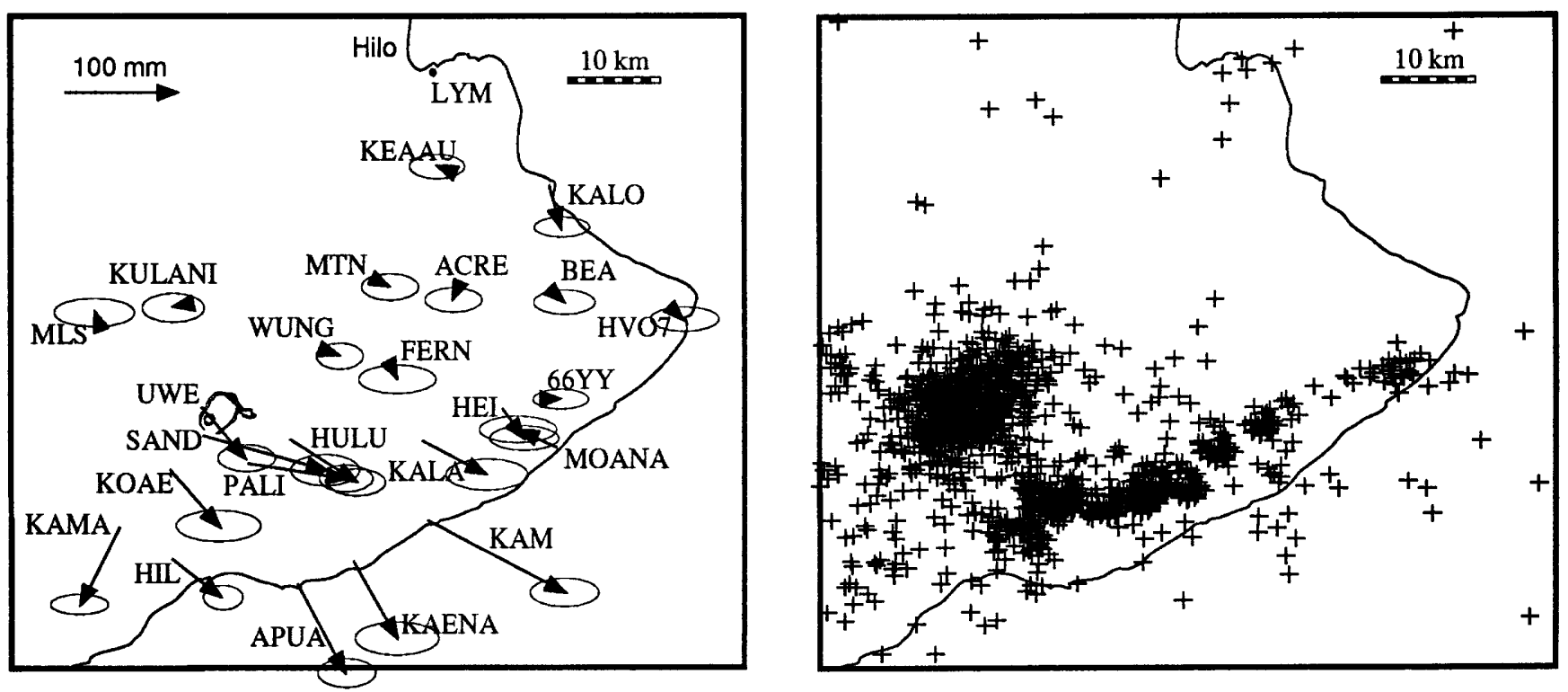

Figure 17. GPS-measured horizontal displacements on Kilauea from April 1987 to August 1988 and from August 1989 to August 1990. Ellipses represent five times standard error computed using Bernese software package. Earthquake locations for same time periods shown at right.

parameters given in table 11 minimize, in the leastsquares sense, the difference between measured and modeled horizontal displacement. The measured and modeled horizontal displacements are listed in table 11 and shown in figure 18.

Vertical displacement measured using GPS between August 1988 and August 1989 and computed displacement, based on the model derived from horizontal displacement, are given in the lower diagram in figure 18 . Vertical displacement was also measured along a leveling route that was surveyed in February 1988 and again in February 1990 (fig. 19). Both GPS and leveling surveys show the same pattern of changes and as much as $0.25 \mathrm{~m}$ of subsidence, though the results of the leveling surveys are more precise. 


\section{SUMMIT AREA OF MAUNA LOA VOLCANO}

GPS measurements of Mauna Loa were started in 1988 with one station in the summit area and another on the west

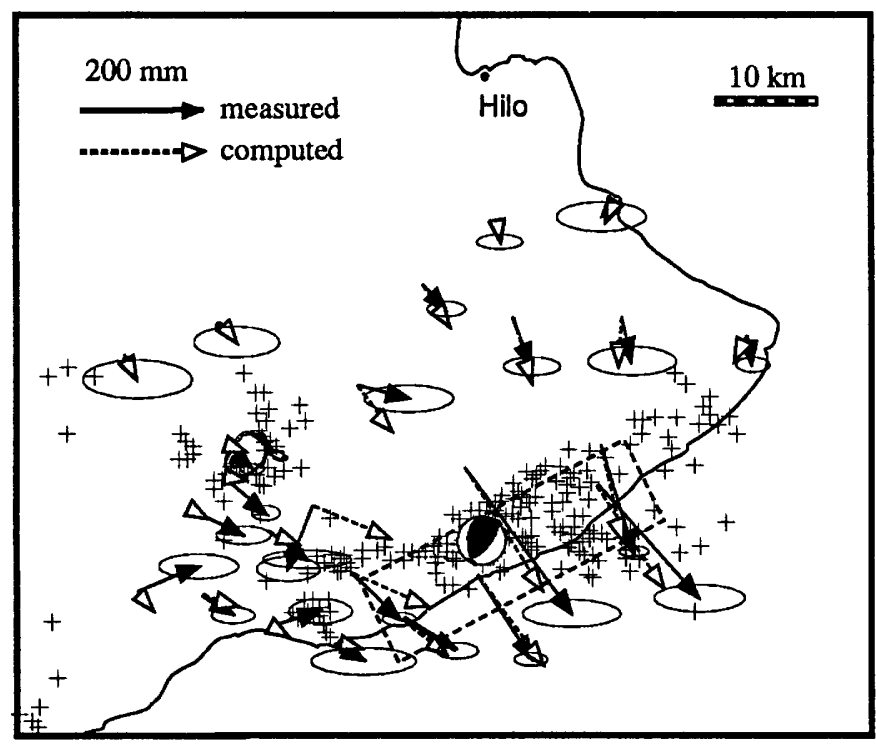

flank at the 2,700-m elevation. In 1989 and 1990 these two stations were remeasured and new stations established on the north and the southeast flanks of the volcano.

Since 1988, the summit station ML1 has moved no more than $20 \mathrm{~mm}$ horizontally relative to OUO on the west flank and less than $50 \mathrm{~mm}$ vertically (fig. 20). These measured changes are within the accuracy of our surveys, and so no significant ground displacement was measured using GPS. Results of trilateration measurements made across a network that covers the summit area of Mauna Loa indicated ML1 moved less than $20 \mathrm{~mm}$ between 1988 and 1990; results of leveling surveys also conducted in the summit area show ML1 was raised $0.17 \mathrm{~m}$ since the 1984
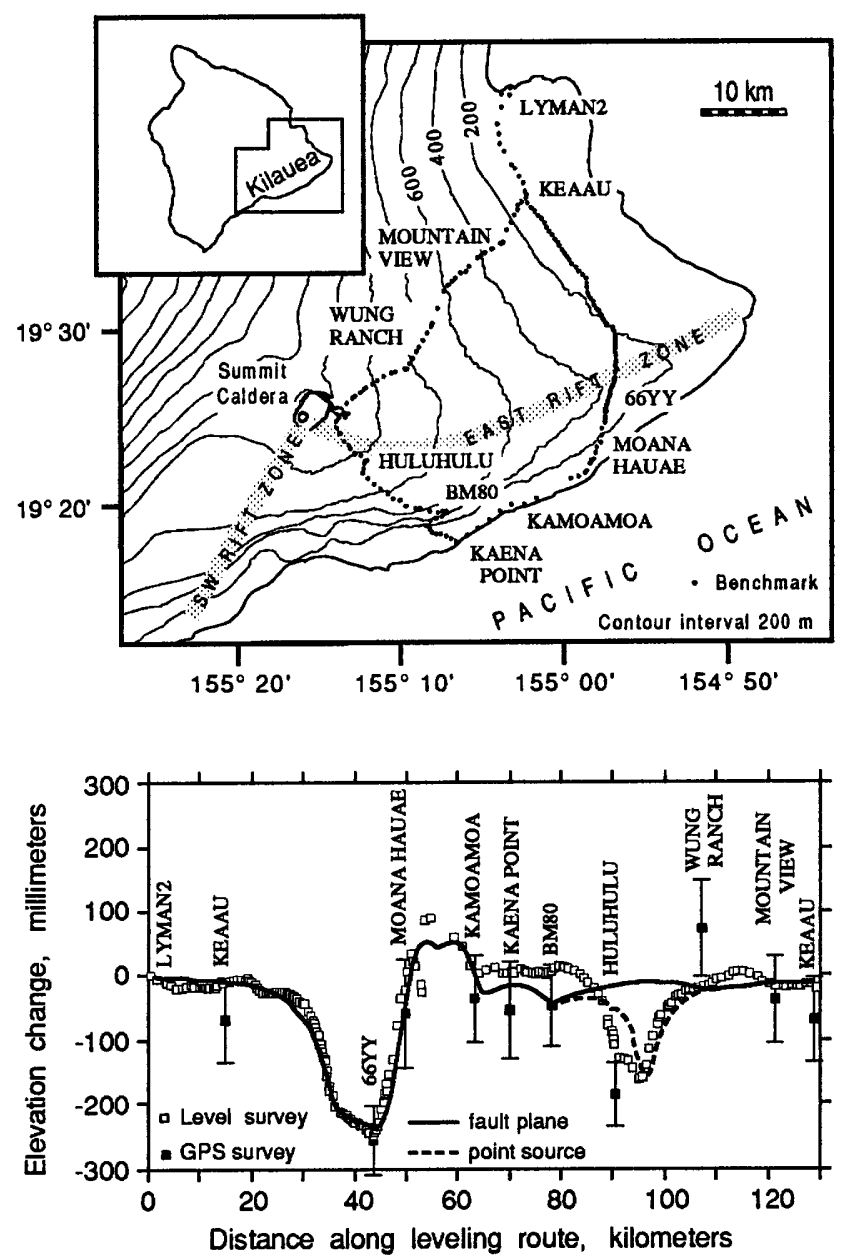

Figure 18. Surface displacements from August 1988 to August 1989 associated with magnitude 6.1 earthquake on June 26, 1989, beneath south flank of Kilauea. All displacements are relative to LYMAN2. Top: Measured horizontal displacements are shown as solid vectors; computed displacements, based on model parameters listed in table 11, shown as dashed vectors. Ellipses represent five times standard error computed using Bernese software package. Surface projection of rectangular sheet model indicated as dashed rectangle. Focal mechanism, located at earthquake epicenter, indicates seaward displacement of the upper portion of south flank. Bottom: Top numbers are measured vertical changes; bottom numbers in brackets are computed vertical changes based on model parameters listed in table 10.
Figure 19. Comparison of measured and computed vertical changes associated with the June 26, 1989, earthquake. Top: Location of leveling route and GPS stations used in bottom diagram. Bottom: Elevation changes as function of distance along leveling route from Hilo. Results of leveling surveys shown as open squares; results of GPS surveys shown as solid squares. (Error bars on GPS measurements are five times standard error computed using Bernese software package.) Solid line is computed vertical changes based on model parameters listed in table 11. In bottom diagram, short, dashed line between HULUHULU and WUNG RANCH includes local subsidence of summit area. 
Table 11. Model calculations for the June 1989 earthquake.

\begin{tabular}{|c|c|c|c|c|c|c|}
\hline \multirow[t]{2}{*}{ Model parameters: } & \multicolumn{2}{|c|}{$\begin{array}{l}\text { latitude } \\
\text { longitude } \\
\text { strike angle from north } \\
\text { dip angle }\end{array}$} & $\begin{array}{c}19.2333 \\
155.1000 \\
60^{\circ} \\
5^{\circ}\end{array}$ & \multicolumn{2}{|c|}{$\begin{array}{l}\text { depth to the source } \\
\text { length of the source } \\
\text { width of the source } \\
\text { dip-slip displacement }\end{array}$} & \multirow[t]{2}{*}{$\begin{array}{l}6 \mathrm{~km} \\
27 \mathrm{~km} \\
12 \mathrm{~km} \\
-1.2 \mathrm{~m}\end{array}$} \\
\hline & \multicolumn{2}{|c|}{$\begin{array}{l}\text { north/south } \\
\text { measured, } \mathrm{mm} \text { model, mm }\end{array}$} & \multicolumn{2}{|c|}{ east/west } & up/down & \\
\hline $\begin{array}{l}\text { LYMAN2* } \\
\text { KEEAU } \\
\text { 66YY } \\
\text { APUA POINT } \\
\text { BM80-1 } \\
\text { HAWAIIAN ACRES } \\
\text { HAWAIIAN BEACHES } \\
\text { HILINA PALI } \\
\text { HULUHULU** } \\
\text { HVO7 } \\
\text { KAENA POINT } \\
\text { KALALUA } \\
\text { KALOLI-2 } \\
\text { KAMAKAIA** } \\
\text { KAMOAMOA } \\
\text { KAPUKAPU } \\
\text { KOAE** } \\
\text { KULANI } \\
\text { MAUNA LOA STRIP } \\
\text { MOANA HAUAE } \\
\text { MOUNTAIN VIEW } \\
\text { PALI } \\
\text { SANDHILL** } \\
\text { UWEKAHUNA** } \\
\text { WUNG RANCH }\end{array}$ & $\begin{array}{r}0 \\
0 \\
-208 \\
-40 \\
-85 \\
-82 \\
-64 \\
-20 \\
-82 \\
-42 \\
-110 \\
-268 \\
-41 \\
29 \\
-191 \\
9 \\
-53 \\
-28 \\
-16 \\
-227 \\
-24 \\
-38 \\
-53 \\
-38 \\
-7\end{array}$ & $\begin{array}{r}0 \\
-14 \\
-200 \\
3 \\
-28 \\
-61 \\
-54 \\
7 \\
-33 \\
-11 \\
-114 \\
-248 \\
-12 \\
7 \\
-200 \\
9 \\
4 \\
-1 \\
3 \\
-196 \\
-26 \\
-2 \\
-1 \\
-3 \\
-39\end{array}$ & $\begin{array}{r}0 \\
18 \\
28 \\
14 \\
69 \\
61 \\
21 \\
41 \\
-45 \\
7 \\
122 \\
188 \\
-47 \\
87 \\
118 \\
150 \\
88 \\
-44 \\
32 \\
176 \\
28 \\
73 \\
51 \\
32 \\
71\end{array}$ & $\begin{array}{r}0 \\
3 \\
11 \\
27 \\
152 \\
15 \\
-17 \\
16 \\
84 \\
-14 \\
84 \\
152 \\
-4 \\
8 \\
127 \\
22 \\
17 \\
9 \\
6 \\
110 \\
14 \\
43 \\
23 \\
21 \\
40\end{array}$ & $\begin{array}{r}0 \\
-72 \\
-221 \\
-55 \\
-57 \\
79 \\
45 \\
69 \\
-161 \\
-36 \\
-53 \\
-273 \\
11 \\
14 \\
-68 \\
182 \\
73 \\
-79 \\
147 \\
-49 \\
-20 \\
-95 \\
-111 \\
-40 \\
84\end{array}$ & $\begin{array}{r}0 \\
-4 \\
-229 \\
-7 \\
-121 \\
-22 \\
-20 \\
-1 \\
-38 \\
-3 \\
-24 \\
-262 \\
-2 \\
1 \\
-71 \\
-3 \\
-1 \\
-1 \\
0 \\
-31 \\
-9 \\
-11 \\
-4 \\
-4 \\
-19\end{array}$ \\
\hline $\begin{array}{l}\text { Root-mean-square differences } \\
\text { (measured minus observed) }\end{array}$ & & & & 54 & & \\
\hline
\end{tabular}

*All displacements, expressed as millimeters, are relative to LYMAN2.

**These stations were not used to compute the root-mean-square values shown at the bottom.
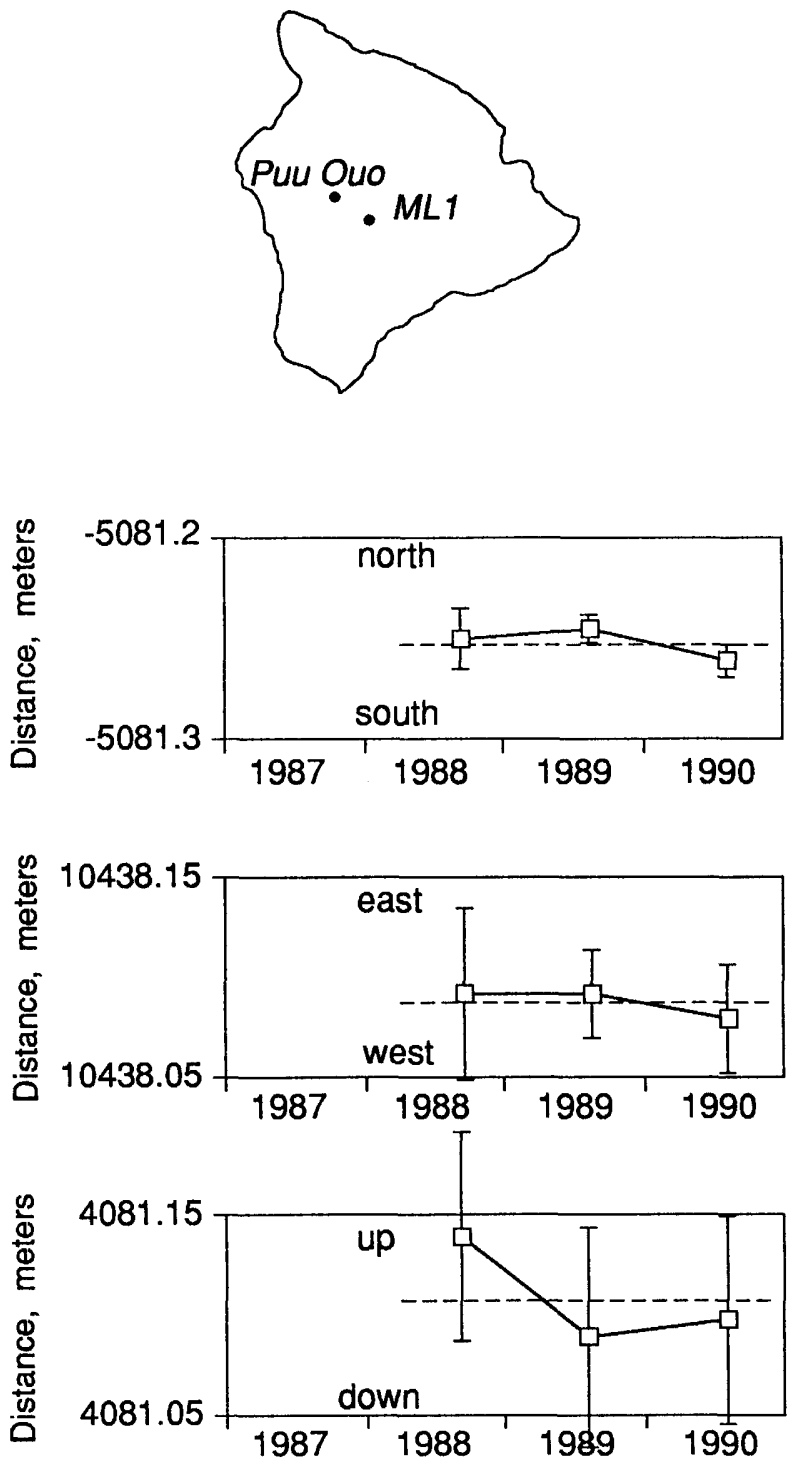

Figure 20. Three-dimensional position of ML1 in summit area of Mauna Loa, relative to OUO on west slope of volcano. Dashed horizontal lines indicate no significant changes were measured between ML1 and OUO during period. 

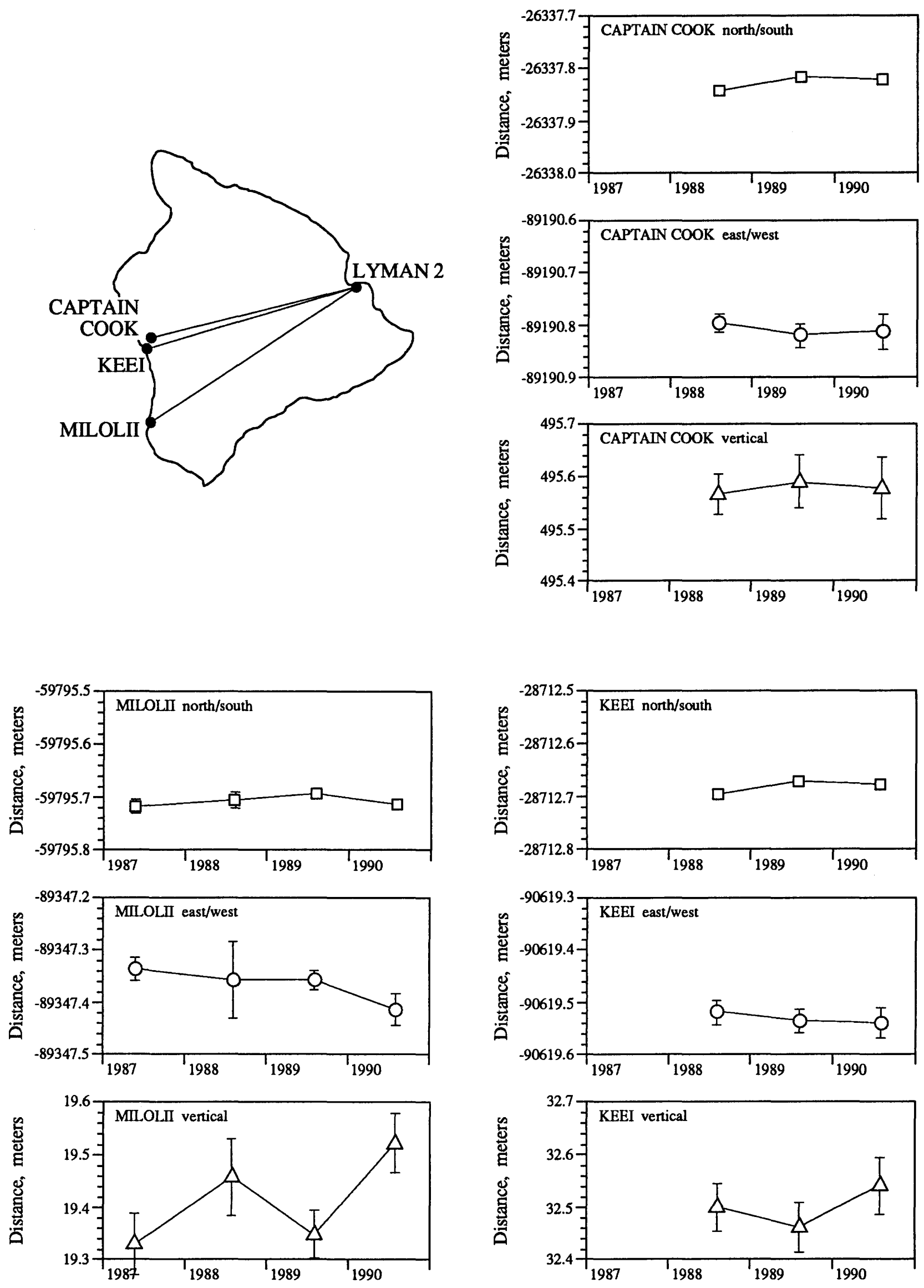
eruption of Mauna Loa, though most of the uplift probably occurred before 1986 (Hawaiian Volcano Observatory, unpub. data).

\section{KEALAKEKUA FAULT SYSTEM}

Three stations have been measured annually along the southwest coast of Hawaii (fig. 21), along a strip that encompasses the Kealakekua fault system. This fault system on the west flank of Mauna Loa is probably similar in origin and operation to the more active and more pronounced Hilina Pali fault system along the south flank of Kilauea. Both fault systems have arcuate, normal faults that formed during sudden seaward displacement of the flank.

Since 1950, three damaging earthquakes, all believed to be greater than magnitude 6.0 , occurred along the west flank of Mauna Loa (Nakata and others, 1990). Continued seismicity at a rate one-quarter to one-half the rate along the south flank of Kilauea suggests ground displacement may be occurring along the southwest coast of Hawaii.

MILOLII may have moved seaward as much as 80 mm between 1987 and 1990. This displacement is consistent with westward slip directions determined by Bryan and Johnson (1991) from focal mechanisms beneath this portion of the island. The vertical positions of MILOLII varied greatly, in part because of the inaccuracy of the 1988 survey and, perhaps, because of an error in measuring the antenna height in 1990. Additional measurements will either confirm, or refute, our apparent detection of seaward displacement along the west coast of Mauna Loa.

\section{GPS AS A TOOL TO STUDY ACTIVE VOLCANOES}

Most, if not all, volcanic eruptions are preceded by vertical and horizontal displacement of the Earth's surface, often occurring near the eventual eruptive site. Kilauea volcano in Hawaii is only one of many such examples. Presumably, the displacement is a response of the crust to accumulation of magma or buildup of pressure within a magma reservoir. Measurements made at many different volcanoes show that the displacement may precede an eruption by as much as several years. Often, a rapid increase in rate of displacement occurs a few hours to a few days before the start of eruptive activity. Among the challenges of understanding active volcanoes and predicting their eruptions are those associated with measuring the displacement of the Earth's surface when the amount of displacement is small.

Figure 21. GPS positions of three stations located along southwest coast of Hawaii, along the Kealakekua fault system.
GPS is a new scientific tool that meets this challenge. The ability to record three-dimensional surface displacement at the centimeter level over distances of tens to hundreds of kilometers makes GPS ideal in the study of active volcanoes. Furthermore, GPS stations can be located in remote and rugged terrain and do not require that stations be intervisible. Weather conditions under which GPS measurements can be made are less restrictive than conventional land-surveying techniques.

Besides Hawaiian volcanoes, GPS surveys have also been conducted at Izu Peninsula, Japan (Shimada and others, 1990); Yellowstone caldera, Wyoming (Meertens and others, 1990); Hekla, Iceland (Sigmundsson and others, 1991); Mono Craters, California (Marshall and Stein, 1991) and Taupo Volcanic Zone, New Zealand (Meertens and others, 1991). The number of active volcanoes surveyed by GPS will continue to grow as ground receivers become less expensive and data processing becomes more automatic.

\section{ACKNOWLEDGMENTS}

We are indebted to the many people who participated in the surveys described in this paper. Particular thanks goes to M. Sako, A. Miklius, and K. Clark. Work was also done by D. Benson, P. Delaney, T. Elias, G. Hamilton, R. Hanatani, K. Honma, J. Kauahikaua, T. Neal, G. Punawai, J. Stowell, and K. Yamashita. Also we thank the support received from the staff of the Hawaiian Volcano Observatory and the comments and suggestions made by R. Stein and P. Segall.

\section{REFERENCES}

Beutler, G., Bauersima, I., Gurtner, W., Rothacher, M., Schildkecht, T., Mader G.L., and Abell, M.D., 1987, Evaluation of the 1984 Alaska Global Positioning System campaign with the Bernese GPS software: Journal of Geophysical Research, v. 92, no. B2, p. 1295-1303.

Bryan, C.J., and Johnson, C.E., 1991, Block tectonics of the island of Hawaii from a focal mechanism analysis of basal slip: Bulletin of the Seismological Society of America, v. 81, no. 2, p. 491-507.

Chin, M., 1992, CIGNET report, GPS Bulletin, v. 5, no. 1, Commission VIII, International Coordination of Space Techniques for Geodesy and Geodynamics, National Geodetic Survey, Rockville, Maryland, 48 p.

Davis, J.L., Prescott, W.H., Svarc, J.L., and Wendt, K.J., 1989, Assessment of Global Positioning System measurements for studies of crustal deformation: Journal of Geophysical Research, v. 94, no. B10, p. 13,635-13,650.

Decker, R.W., 1987, Dynamics of Hawaiian volcanoes: an overview: U.S. Geological Survey Professional Paper 1350, v. 2, Volcanism in Hawaii, edited by R.W. Decker, T.L. Wright, and P.H. Stauffer, p. 997-1018. 
Decker, R.W., Hill, D.P. and Wright, T.L., 1966, Deformation measurements on Kilauea Volcano, Hawaii: Bulletin Volcanologique, v. 29, p. 721-732.

Decker, R.W., Koyanagi, R.Y., Dvorak, J.J., Lockwood, J.P., Okamura, A.T., Yamashita, K.M., and Tanigawa, W.R., 1983, Seismicity and surface deformation of Mauna Loa Volcano, Hawaii: Eos, American Geophysical Union, Transactions, v. 64 , no. 37 , p. $545-547$.

Dixon, T.H., 1991, An introduction to the Global Positioning System and some geological applications: Reviews of Geophysics, v. 29 , no. 2 , p. $249-276$.

Dvorak, J.J., 1990, Geometry of the September 1971 eruptive fissure at Kilauea volcano, Hawaii: Bulletin of Volcanology, v. 52, p. 507-514.

Dvorak J.J., and Dzurisin, D., 1993, Variations in magma-supply rate at Kilauea Volcano, Hawaii: Journal of Geophysical Research, v. 98 , p. 22,255-22,268.

Dvorak, J.J., Johnson, C., and Tilling, R.I., 1992, Dynamics of Kilauea Volcano: Scientific American, v. 267, no. 2, p. 46-53.

Dvorak, J.J., Okamura, A.T., English, T.T., Koyanagi, R.Y., Nakata, J.S., Sako, M.K., Tanigawa, W.R., and Yamashita, K.M., 1986, Mechanical response of the south flank of Kilauea volcano, Hawaii, to intrusive events along the rift zones: Tectonophysics, v. 124 , p. 193-209.

Dzurisin, D., 1992, Geodetic leveling as a tool for studying restless volcanoes, in Ewart, J.W., and Swanson, D.A., eds., Monitoring Volcanoes: Techniques and Strategies used by the Staff of the Cascades Volcano Observatory, 1980-90: U.S. Geological Survey Bulletin 1966, p. 125-134.

Eaton, J.P., and Murata, K.J., 1960, How volcanoes grow: Science, v. 132 , p. $925-938$.

Fiske, R.S., and Kinoshita, W.T., 1969, Inflation of Kilauea Volcano prior to its 1967-1968 eruption: Science, v. 165, 341-349.

Heliker, C., and Wright, T.L., 1991, The Pu'u O'o-Kupaianaha eruption of Kilauea: Eos, Transactions, American Geophysical Union, v. 72, p. 521 and 526.

Jackson, D.B., Swanson, D.A., Koyanagi, R.Y., and Wright, T.L., 1975, The August and October 1968 east rift eruptions of Kilauea Volcano, Hawaii: U.S. Geological Survey Professional Paper 890, 33 p.

Jaggar, T.A., and Finch R.H., 1929, Tilt records for thirteen years at the Hawaiian Volcano Observatory: Seismological Society of America Bulletin, v. 19, p. 38-51.

Koyanagi, R.Y., Bryan, C.J., Johnson, C.E., Nakata, J.S., and Tanigawa, W.R., 1989, Preliminary evaluation of the 6.1-magnitude Hawaii earthquake of June 25, 1989 and aftershocks: Eos, American Geophysical Union, Transactions, v. 70, p. $1409-1410$.

Lerch, F.J., Klosko, S.M., Laubscher, R.E., and Wagner, C.A., 1979, Gravity model improvement using Geos 3 (GEM 9 and 10): Journal of Geophysical Research, v. 84, no. B8, p. 3897 3916.

Lipman, P.W., Lockwood, J.P., Okamura, R.T., Swanson, D.A., and Yamashita, K.M., 1985, Ground deformation associated with the 1975 magnitude-7.2 earthquake and resulting changes in activity of Kilauea Volcano, Hawaii: U.S. Geological Survey Professional Paper 1276, 45 p.

Lockwood, J.P., Dvorak, J.J., English, T.T., Koyanagi, R.Y., Okamura, A.T., Summers, M.L., and Tanigawa, W.R., 1987, Mauna Loa 1974-1984: a decade of intrusive and extrusive activity: U.S. Geological Survey Professional Paper 1350, v. 1, Volcanism in Hawaii, edited by R.W. Decker, T.L. Wright, and P.H. Stauffer, p. 537-570.

Macdonald, G.A., Abbott, A.T., and Peterson, F.L., 1983, Volcanoes in the Sea, The Geology of Hawaii: Univ. Hawaii Press, Honolulu, Hawaii, second edition, 517 p.

Marshall, G.A., and Stein, R.S., 1991, Monitoring ground deformation at Mono Craters, California, using a dense GPS network: Eos, American Geophysical Union, Transactions, v. 72, no. 44, supplement, p. 118.

Meertens, C.M., Perin, B., Rocken, C., Blick, G.H., Darby, D.J., Otway, P., Scott, B., Williams, R., Wood, P., Van Dissen, R., Bennie, S., Walcott, R., Brown, K., Stirling, C., Herries, N., and Luo, X., 1991, New Zealand Taupo Volcanic Zone GPS project: tectonics, field campaign and near real-time results: Eos, American Geophysical Union, Transactions, v. 72, no. 17 , p. 92.

Meertens, C.M., Smith, R.B., and Reilinger, R., 1990, The Yellowstone crustal deformation experiment: intercampaign comparison of the 1987-1989 GPS results from the Yellowstone caldera-Hebgen Lake-Teton fault network: Eos, American Geophysical Union, Transactions, v. 71, no. 17, p. 478 .

Moore, J.G., 1987, Subsidence of the Hawaiian Ridge, in Decker, R.W., Wright, T.L., and Stauffer, P.H., Volcanism in Hawaii, v. 1: U.S. Geological Survey Professional Paper 1350 , p. $85-100$.

Nakata, J., Tanigawa, W., and Dvorak, J.J., 1990, Comparison of earthquake activity along the west flank of Mauna Loa volcano and the south flank of Kilauea volcano, Hawaii: Eos, American Geophysical Union, Transactions, v. 71, p. 1561.

Okada, Y., 1985, Surface deformation due to shear and tensile faults in a half-space: Bulletin of the Seismological Society of America, v. 75, p. 1135-1154.

Okamura, A.T., Dvorak, J.J., Koyanagi, R.Y., and Tanigawa, W.R., 1988, Surface deformation during dike propagation: U.S. Geological Survey Professional Paper 1463, The Puu Oo Eruption of Kilauea Volcano, Hawaii: Episodes 1 through 20, January 3, 1983, Through June 8, 1984, edited by E.W. Wolfe, 165-181.

Prescott, W.H., Davis, J.L., and Svarc, J.L., 1989, Global Positioning System measurements for crustal deformation: precision and accuracy: Science, v. 244, p. 1337-1340.

Remondi, B.W., and Hofmann-Wellenhof, B., 1990, GPS broadcast orbits versus precise orbits: a comparison study: Global Positioning System: An Overview, Symposium No. 102, edited by Bock, Y., and Leppar, N., Springer-Verlag, New York, p. 203-217.

Schultz, B.E., Ho, C.S., Abusali, P.A.M., and Tapley, B.D., 1990, CASA UNO GPS orbit and baseline experiments: Geophysical Research Letters, v. 17, no. 5, p. 643-646.

Shimada, S., Fujinawa, Y., Sekiguchi, S., Ohmi, S., Eguchi, T., and Okada, Y., 1990, Detection of a volcanic fracture opening in Japan using Global Positioning System measurements: Nature, v. 343, p. 631-633.

Sigmundsson, F., Einarsson, P., Hackman, C., Bilham, R., and Thorbergsson, G., 1991, Displacement of GPS control points associated with the 1991 Hekla eruption: Eos, American Geophysical Union, Transactions, v. 72 , no. 44, supplement, p. 115. 
Swanson, D.A., Duffield, W.A., and Fiske, F.S., 1976, Displacement of the south flank of Kilauea Volcano: the result of forceful intrusion of magma into the rift zones: U.S. Geological Survey Professional Paper 963, 39 p.

Tilling, R.I., and Dvorak, J.J., 1993, Anatomy of a basaltic volcano: Kilauea, Hawaii: Nature, v. 363, p. 125-133.

Ware, R.H., Rocken, C., and Hurst, K.J., 1986, A Global Positioning System baseline determination including bias fixing and water vapor radiometer corrections: Journal of Geophysical Research, v. 91, no. B9, p. 9183-9192.

Watts, A.B., 1979, On geoid heights derived from Geos 3 altimeter data along the Hawaiian-Emperor Seamount Chain: Journal of Geophysical Research, v. 84, no. B8, p. 38173826.
Wells, D.E., Beck, N., Delikaraoglou, D., Kleusberg, A., Krakiwsky, E.J., Lachapelle, G., Langley, R.B., Nakiboglu, M., Schwarz, K.P., Tranquilla, J.M., and Vanicek, P., 1986, Guide to GPS Positioning, Canadian GPS Associates, Fredericton, N.B., Canada.

Wright, T.L., and Fiske, R.S., 1971, Origin of the differentiated and hybrid lavas of Kilauea Volcano, Hawaii: Journal of Petrology, v. 12, p. 1-65.

Yamashita, K.M., 1992, Single-setup leveling used to monitor vertical displacement (tilt) on Cascades volcanoes, in Ewart, J.W., and Swanson, D.A., eds., Monitoring Volcanoes: Techniques and Strategies used by the Staff of the Cascades Volcano Observatory, 1980-90: U.S. Geological Survey Bulletin 1966, p. 143-149. 


\section{SELECTED SERIES OF U.S. GEOLOGICAL SURVEY PUBLICATIONS}

\section{Periodicals}

Earthquakes \& Volcanoes (issued bimonthly).

Preliminary Determination of Epicenters (issued monthly).

\section{Technical Books and Reports}

Professional Papers are mainly comprehensive scientific reports of wide and lasting interest and importance to professional scientists and engineers. Included are reports on the results of resource studies and of topographic, hydrologic, and geologic investigations. They also include collections of related papers addressing different aspects of a single scientific topic.

Bulletins contain significant data and interpretations that are of lasting scientific interest but are generally more limited in scope or geographic coverage than Professional Papers. They include the results of resource studies and of geologic and topographic investigations, as well as collections of short papers related to a specific topic.

Water-Supply Papers are comprehensive reports that present significant interpretive results of hydrologic investigations of wide interest to professional geologists, hydrologists, and engineers. The series covers investigations in all phases of hydrology, including hydrogeology, availability of water, quality of water, and use of water.

Circulars present administrative information or important scientific information of wide popular interest in a format designed for distribution at no cost to the public. Information is usually of shortterm interest.

Water-Resource Investigations Reports are papers of an interpretive nature made available to the public outside the formal USGS publications series. Copies are reproduced on request unlike formal USGS publications, and they are also available for public inspection at depositories indicated in USGS catalogs.

Open-File Reports include unpublished manuscript reports, maps, and other material that are made available for public consultation at depositories. They are a nonpermanent form of publication that may be cited in other publications as sources of information.

\section{Maps}

Geologic Quadrangle Maps are multicolor geologic maps on topographic bases in $71 / 2$ - or 15 -minute quadrangle formats (scales mainly $1: 24,000$ or $1: 62,500$ ) showing bedrock, surficial, or engineering geology. Maps generally include brief texts; some maps include structure and columnar sections only.

Geophysical Investigations Maps are on topographic or planimetric bases at various scales; they show results of surveys using geophysical techniques, such as gravity, magnetic, seismic, or radioactivity, which reflect subsurface structures that are of economic or geologic significance. Many maps include correlations with the geology.

Miscellaneous Investigations Series Maps are on planimetric or topographic bases of regular and irregular areas at various scales; they present a wide variety of format and subject matter. The series also includes 7 1/2-minute quadrangle photogeologic maps on planimetric bases that show geology as interpreted from aerial photographs. Series also includes maps of Mars and the Moon.
Coal Investigations Maps are geologic maps on topographic or planimetric bases at various scales showing bedrock or surficial geology, stratigraphy, and structural relations in certain coal-resource areas.

Oil and Gas Investigations Charts show stratigraphic information for certain oil and gas fields and other areas having petroleum potential.

Miscellaneous Field Studies Maps are multicolor or black-andwhite maps on topographic or planimetric bases on quadrangle or irregular areas at various scales. Pre-1971 maps show bedrock geology in relation to specific mining or mineral-deposit problems; post-1971 maps are primarily black-and-white maps on various subjects, such as environmental studies or wilderness mineral investigations.

Hydrologic Investigations Atlases are multicolor or black-andwhite maps on topographic or planimetric bases presenting a wide range of geohydrologic data of both regular and irregular areas; principal scale is $1: 24,000$, and regional studies are at $1: 250,000$ scale or smaller.

\section{Catalogs}

Permanent catalogs, as well as some others, giving comprehensive listings of U.S. Geological Survey publications are available under the conditions indicated below from the U.S. Geological Survey, Books and Open-File Reports Sales, Federal Center, Box 25286, Denver, CO 80225. (See latest Price and Availability List.)

"Publications of the Geological Survey, 1879-1961" may be purchased by mail and over the counter in paperback book form and as a set of microfiche.

"Publications of the Geological Survey, 1962-1970" may be purchased by mail and over the counter in paperback book form and as a set of microfiche.

"Publications of the Geological Survey, 1971-1981" may be purchased by mail and over the counter in paperback book form (two volumes, publications listing and index) and as a set of microfiche.

Supplements for 1982, 1983, 1984, 1985, 1986, and for subsequent years since the last permanent catalog may be purchased by mail and over the counter in paperback book form.

State catalogs, "List of U.S. Geological Survey Geologic and Water-Supply Reports and Maps For (State)," may be purchased by mail and over the counter in paperback booklet form only.

"Price and Availability List of U.S. Geological Survey Publications," issued annually, is available free of charge in paperback booklet form only.

Selected copies of a monthly catalog "New Publications of the U.S. Geological Survey" are available free of charge by mail or may be obtained over the counter in paperback booklet form only. Those wishing a free subscription to the monthly catalog "New Publications of the U.S. Geological Survey" should write to the U.S. Geological Survey, 582 National Center, Reston, VA 22092.

Note.--Prices of Government publications listed in older catalogs, announcements, and publications may be incorrect. Therefore, the prices charged may differ from the prices in catalogs, announcements, and publications. 


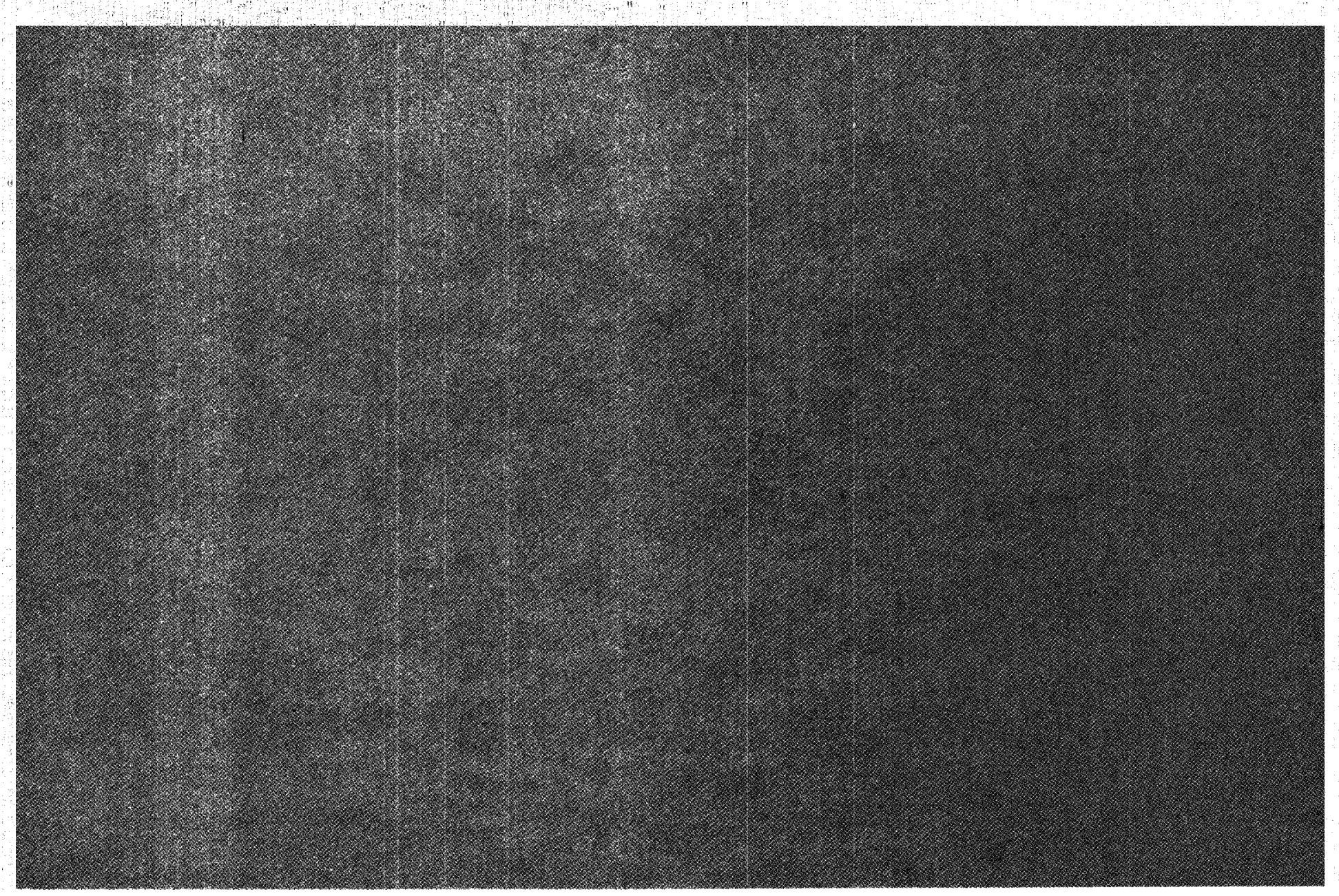

